Portland State University

PDXScholar

1986

\title{
The stratigraphy and structure of the Columbia River basalt group in the Salmon River area, Oregon
}

\author{
Martin S. Burck \\ Portland State University
}

Follow this and additional works at: https://pdxscholar.library.pdx.edu/open_access_etds

Part of the Geology Commons, and the Stratigraphy Commons

Let us know how access to this document benefits you.

\section{Recommended Citation}

Burck, Martin S., "The stratigraphy and structure of the Columbia River basalt group in the Salmon River area, Oregon" (1986). Dissertations and Theses. Paper 3583.

https://doi.org/10.15760/etd.5467

This Thesis is brought to you for free and open access. It has been accepted for inclusion in Dissertations and Theses by an authorized administrator of PDXScholar. Please contact us if we can make this document more accessible: pdxscholar@pdx.edu. 
ABSTRACT OF THE THESIS OF Martin S. Burck for the Master of Science in Geology presented March 21, 1986.

Title: The Stratigraphy and Structure of the Columbia River Basalt Group in the Salmon River area, Oregon.

APPROVED BY MEMBERS OF THE THESIS COMMITTEE:

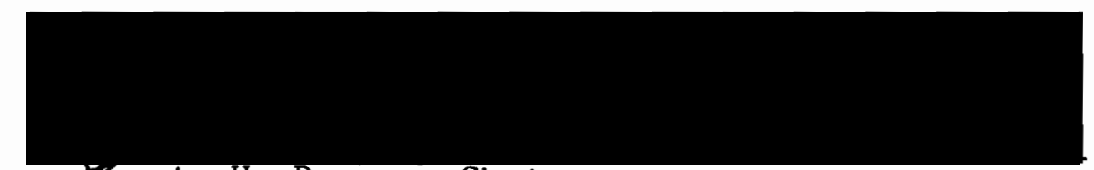

Jarvin H. Beeson, Chairman

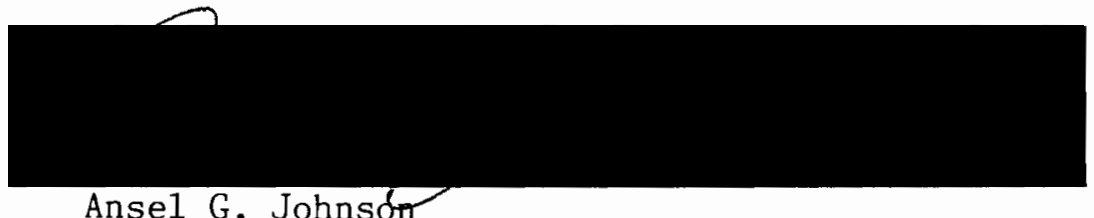

Ansel G. Johnsớn

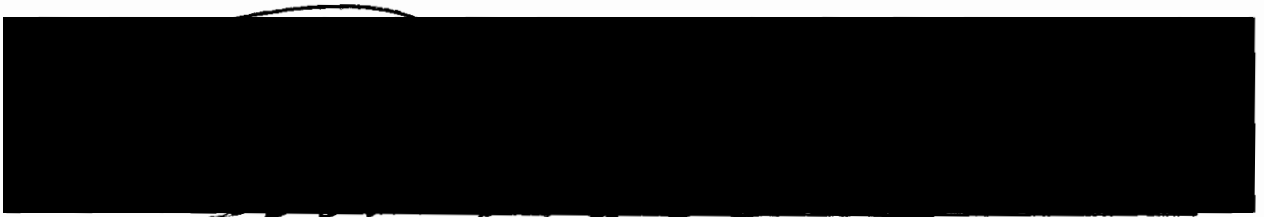

Leonard A. Palmer

2

Approximate1y $16 \mathrm{~km}$ of Columbia River basalt are exposed

in the Salmon River area to the south and to the west of Mount Hood, Oregon. A maximum composite basalt section composed of 15 flows and totaling $461 \mathrm{~m}$ is exposed in discontinuous areas of outcrop. The Columbia River basalt in the Salmon River area belongs to the Grande Ronde Basalt and the Frenchman Springs Member of the Wanapum Basalt. The Grande Ronde Basalt section (6 flows) was mapped as two chemically distinct units referred to as $10 \mathrm{w}-\mathrm{MgO}$ (older) and high-MgO (younger) Grande Ronde Basalt. At least one 
interfingered flow of the Prineville chemical type occurs within the low-MgO section. The Prineville flow represents the oldest Columbia River basalt exposed in the Salmon River area.

The Frenchman Springs section ( 8 flows) is represented by four distinct chemical units referred to as the basalt of Ginkgo, the basalt of Silver Falls, the basalt of Sand Hollow, and the basalt of Sentinel Gap.

Stratigraphic division of the Columbia River basalt units was based on geochemistry determined by INAA for trace elements and by $x$-ray fluoresence spectrometry for major oxides. The definition of geochemical units was aided by stratigraphic position, texture, and phenocryst/glomerocryst abundance.

The Grande Ronde Basalt and the Frenchman Springs basalt originated in the Columbia Plateau and flowed westward through the Cascade Range along a $72 \mathrm{~km}$ wide tectonic depression. The Prineville flow is chemically similar to flows that originated near the Bowman Dam (formerly the Prineville Dam) located $70-80 \mathrm{~km}$ to the southeast.

The distribution of Columbia River basalt in the Salmon River area was controlled by structures that developed gradually. The formation of these structures began during the incursion of the Grande Ronde Basalt and consisted of northeast-trending folds and a northwest-trending fault zone that displays components of strike-slip and vertical displacement. This approximately $\mathrm{N} 30^{\circ}$ W-trending fault zone extends the entire length $(30 \mathrm{~km})$ of the Salmon River area. 
The Ginkgo intracanyon flow may have passed through the Salmon River area within the projected continuation of the Mt. Hood-The Dalles syncline. Rapid infilling by subsequent flows restored the low relief nature of the basalt surface by the end of Frenchman Springs time.

Persistent north-south compressional stresses resulted in the development of large scale folds that were imprinted by the existing, continually developing small scale-folds. Continual length-shortening resulted in northeast-trending thrusts and highangle-reverse faults along the weakened limbs of anticlinal structures. Thrust faults are associated with extensive breccias and may show up to $122 \mathrm{~m}$ of stratigraphic displacement.

The northwest-trending (predominently $\mathrm{N} 30^{\circ} \mathrm{W}$ ) fault zone exists along the western edge of the Salmon River area. Northeast-trending structures appear to terminate against it. The regional, right-lateral, strike-slip sense of motion along this zone is masked in the Salmon River area where terminated anticlines and synclines create a vertical sense of displacement. The $\mathrm{N} 30^{\circ} \mathrm{W}$ structural zone was active throughout the history of structural development in the Salmon River area and has a complimentary relationship with the northeast-trending structures. The prominent overall northwest-trend of the basalt outcrop pattern in the Salmon River area is related to the presence of the northwest-trending structures located along its western edge. Northeast-trending normal faults are the youngest structures recorded by the tectonic history of the Columbia River 
basalt in the Salmon River area. This relationship was determined where normal faults cut previously formed thrust breccias. The late forming normal faults are not related to the predominent, northeast-trending structures and indicate a fluctuation in the regional, compressive stress pattern that may exist today. Normal faulting may also be related to the emplacement of semi-discordant sills of silicic volcanic material observed within the basalt section, and other intrusive features such as the Still Creek pluton located $1.5 \mathrm{~km}$ to the northeast. 
THE STRATIGRAPHY AND STRUCTURE OF THE COLUMBIA

RIVER BASALT GROUP IN THE SALMON RIVER

AREA, OREGON

by

MARTIN STUART BURCK

A thesis submitted in partial fulfillment of the requirements for the degree of

\author{
MASTER OF SCIENCE \\ in \\ GEOLOGY
}

Portland State University

1986 
TO THE OFFICE OF GRADUATE STUDIES AND RESEARCH:

The members of the Committee approve the thesis of Martin S. Burck presented March 21, 1986.



Paul E. Hammond, Head, Department of Geology Bernard Ross, Dean of Graduate Studies and Research 


\section{ACKNOWLEDGMENTS}

Upon completion of this study, I would like to thank those people that are directly responsible for my success. Dr. Monty Elliott, Dr. William Purdom, and Dr. Jad D'Allura (geology department SOSC, Ashland, Oregon) are credited with supplying the geologic background and field sense nescesary to complete this project and a special thanks is extended to Monty for encouraging my venture into graduate school. Dr. Marvin H. Beeson (thesis advisor) is also appreciated for suggesting the project, and for his continual interest and enthusiam as the study progressed. I would also like to thank members of the faculty who reviewed and edited my work as it progressed: Dr Johnson, Dr Palmer, and Dr Hammond. I am also grateful for the support and assistance I received from members of my family and friends. 
TABLE OF CONTENTS

PAGE

Acknowledgements ............. . . i ii

List of Tables................ . . vii

List of Figures ............... viii

\section{Chapter}

I Introduction .............. 1

Geographic Setting ........ 2

Exposure And Distribution of Basalt

Outcrop. . . . . . . . . . . 4

Previous Work In The Salmon River Area . . 7

Regional Geology .......... 7

Cascades . . . . . . . . . 7

Columbia River Basalt Group. . . . . . 9

Regional Yakima Basalt Subgroup Stratigraphy . 9

Grande Ronde Basalt. . . . . . . . 13

Vantage Member ............ 15

Wanapum Basalt .......... 16

Procedure and Methods ......... 16

Field Work . . . . . . . . . 16

Laboratory Work. . . . . . . 18

II Salmon River Area Basalt Stratigraphy . . . . 20

Grande Ronde Basalt . . . . . . . 22

Low-MgO Grande Ronde Basalt. . . . . . 25

High-MgO Grande Ronde Basalt . . . . . 25

Prineville Chemical Type ....... 26

Vantage Interbed ......... 31 
CHAPTER

PAGE

Frenchman Springs Member . . . . . . 32

Basalt of Ginkgo .......... . 33

Basalt of Silver Falls . . . . . . 38

Basalt of Sand Hollow . . . . . . 40

Basalt of Sentinel Gap... . . . . 42

Summary of Stratigraphy . . . . . . . . 46

III Salmon River Area Basalt Structure . . . . . . 48

Folds .................. 49

Faults.............. 56

Northeast-Trending Faults . . . . . 57

Northwest-Trending Faults .. . . . 62

Joints . . . . . . . . . . . 65

Summary of Structure . . . . . . . . 66

IV Geologic History .. . . . . . . . . . 68

V Discussion and Conclusions . . . . . . . . 82

REFERENCES CITED . . . . . . . . . . . . . . 87

APPENDIX

A SUMMARY OF MAJOR OXIDE COMPOSITION FOR LOW-MgO GRANDE RONDE BASALT . . . . . . . . 93

B SUMMARY OF TRACE ELEMENT COMPOSITION FOR LOW-MgO GRANDE RONDE BASALT . . . . . . . . 94

C SUMMARY OF MAJOR OXIDE COMPOSITION FOR HIGH-MgO GRANDE RONDE BASALT . . . . . . . . 95

D SUMMARY OF TRACE ELEMENT COMPOSITION FOR HIGH-MgO GRANDE RONDE BASALT . . . . . . . . 96

E SUMMARY OF MAJOR OXIDE COMPOSITION FOR BASALT OF GINKGO . . . . . . . . . . . . 97

F SUMMARY OF TRACE ELEMENT COMPOSITION FOR BASALT OF GINKGO . . . . . . . . . . . . 98 
G SUMMARY OF MAJOR OXIDE COMPOSITION FOR BASALT OF SILVER FALLS . . . . . . . . . 99

H SUMMARY OF TRACE ELEMENT COMPOSITION FOR BASALT OF SILVER FALLS . . . . . . . . 100

I SUMMARY OF MAJOR OXIDE COMPOSITION FOR BASALT OF SAND HOLLOW . . . . . . . . . 101

J SUMMARY OF TRACE ELEMENT COMPOSITION FOR BASALT OF SAND HOLLOW . . . . . . . . 102

$\mathrm{K}$ SUMMARY OF MAJOR OXIDE COMPOSITION FOR BASALT OF SENTINEL GAP .......... 104

L SUMMARY OF TRACE ELEMENT COMPOSITION FOR BASALT OF SENTINEL GAP .......... 105

Ml SAMPLE LOCATIONS . . . . . . . . . 106

M2 SAMPLE LOCATIONS . . . . . . . . . 107

M3 SAMPLE LOCATIONS . . . . . . . . . 108 


\section{LIST OF TABLES}

TABLE

PAGE

I Average Major Oxide Concentrations ...... 23

II Average Trace Element Concentrations . . . . . 24

II Comparison of the Salmon River area Prineville Chemical Type Composition with other areas . . . 27

IV Comparison of the Salmon River area Sentinel Gap

Composition with the Hood Acres Well....... 44 


\section{LIST OF FIGURES}

FIGURE

PAGE

1. Location Map for the Salmon River Area . . . . . 3

2. Map of the High Cascades, Western Cascades and other geologic provinces of Oregon . . . . . . 5

3. Map of the primary Columbia River basalt exposures within the Salmon River area and commonly referred to locations................ 6

4. Map showing the extent of the Columbia River Basalt Group ................. 10

5. Stratigraphy of the Columbia River Basalt Group. • . 12

6. Map showing the extent of Grande Ronde Basalt . . . 14

7. Map showing the extent of Frenchman Springs basalt . . . . . . . . . . . . . 17

8. Composite stratigraphic columnar section of the Columbia River basalt in the Salmon River area, Oregon . . . . . . . . . . . . . . 21

9. Locations of documented analyses of the Prineville chemical type in central and northwestern Oregon . . 30

10. Correlation of Frenchman Springs terms by Beeson and others (1985) with previous authors . . . . . 34

11. Map of regional structures in the northern Oregon Cascade Range and the northeastern Columbia Plateau ................ . . 50 
FIGURE

PAGE

12. Tectonic map of the southern Salmon River area . . . 52

13. Tectonic map of the northern Salmon River area . . 54

14. Diagram illustrating the relative senses of movement between the $\mathrm{N} 30^{\circ} \mathrm{W}$ structural zone and the folded northeastern block............. 85 
CHAPTER I

INTRODUCTION

The Columbia River Basalt Group (CRBG) represents a thick, laterally extensive accumulation of texturally and 1ithologically similar tholeiitic flood basalts. Early workers found stratigraphic division and correlation of Columbia River basalt (CRB) by lithology and petrography, ineffective. The advent of rapid chemical analysis (major oxide and trace element) advanced the study of CRB stratigraphy to its present state. The chemical data already compiled allows fingerprinting of individual units containing one to several flows. This provides accurate stratigraphic correlation throughout the Columbia Plateau and beyond and is a substantial tool for delineating structure. The essentially horizontal upper cooling surfaces of the basalt flows lend them suitable for structural interpretation. In reconnaissance work, Beeson and Moran (1979b) noted that the Salmon River area is structurally complex with a predominant $\mathrm{N}$ $30^{\circ} \mathrm{W}$ trending structure extending along its length that appears to form a boundary between two regional structural types: (1) the broad gentle folding of the Columbia Plateau to the east, and (2) the right lateral wrench system associated with the Portland Hills type structure to the west (Peck and others, 1964; Beeson and Moran, 1979b). 
The purpose of this study is to develop criteria for describing the stratigraphy and the tectonic history of the CRB in the Salmon River area. Methods used included (1) detailed mapping of structure, (2) sampling individual flows for chemical analysis. Trace element and major oxide composition provides accurate control of stratigraphy and flow distribution. These data also enhance the structural resolution of megascopically similar CRB flows. The success of this study depends on the accuracy of field mapping and chemical analyses to overcome such difficulties as (1) discontinuous exposure, (2) nondistinguishable field appearance of flows, and (3) complex structure. Products of this study include this text, a geologic map, and appropriate cross-sections.

\section{Geographic Setting}

The Salmon River area includes roughly $300 \mathrm{sq} \mathrm{km}$ of northern Oregon's western Cascade Range (Figure 1). It is approximately bounded to the north by Highway 26 (from Alder Creek to Zig Zig) and to the east by the southern flank of the Mt. Hood volcano where the headwaters of the Salmon River is located. From Highway 26, the study area extends $30 \mathrm{~km}$ to the southeast averaging $8 \mathrm{~km}$ in width. Its trend roughly parallels the Cascade axis, and the Salmon River is centrally located along its length. The settlements of Brightwood, Rhododendron, and Zig Zag, Oregon, are adjacent to Highway 26 within the confines of the study area, which is almost entirely contained by T. 3 S., R. 


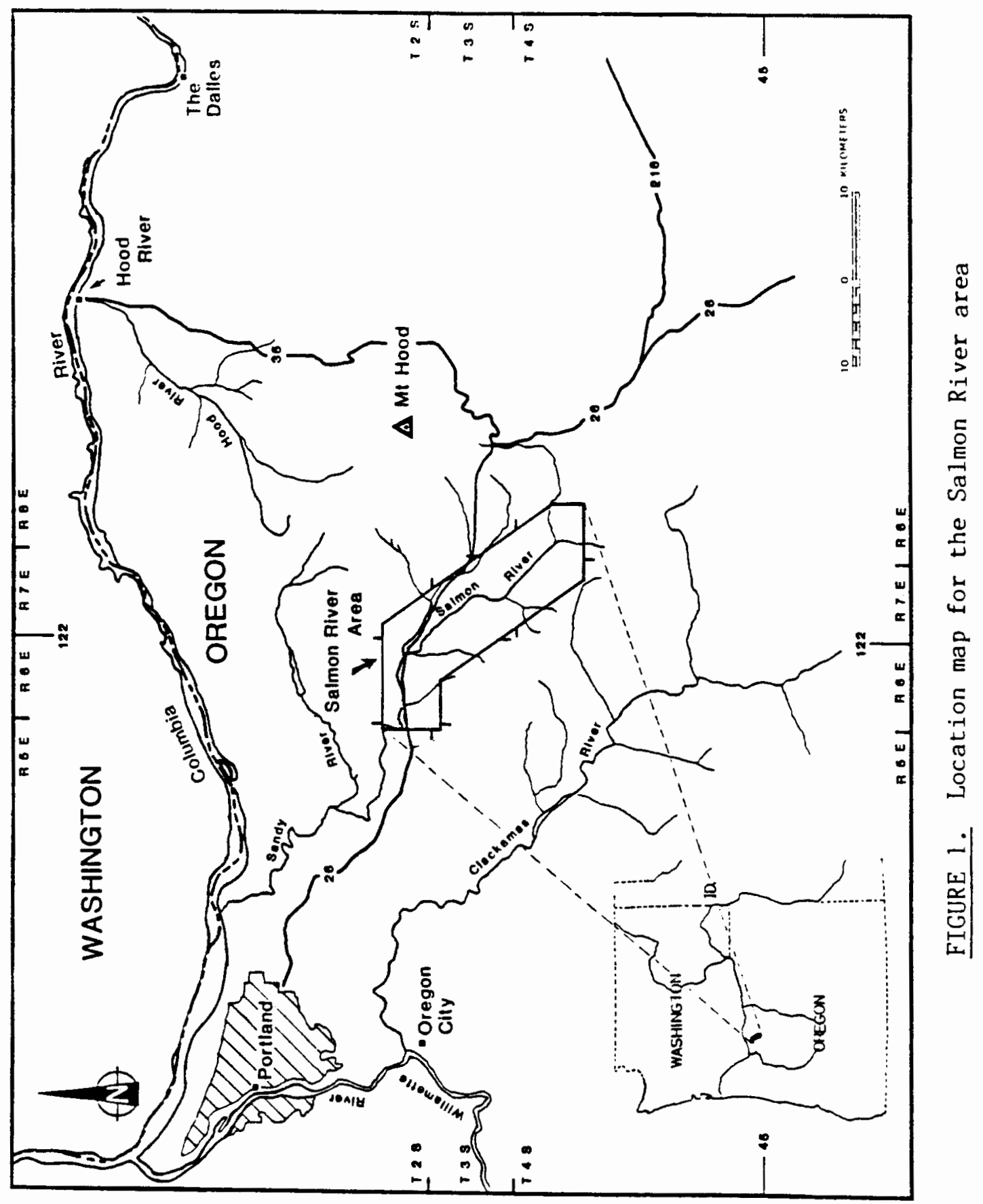


7 E., and T. 4 S., R. 7 E., WBM. The study area lies along the western edge of the High Cascade terrain (Peck and others, 1964; Wise, 1969; Figure 2). Constructional volcanic terrain with a gradual western slope from the western and southwestern flank of Mt. Hood typifies the study area. The maximum relief of the area is 4,195 $\mathrm{ft}$ ranging from 5,045 ft elevation at Devils Peak to 900 ft elevation at the mouth of Alder Creek.

Exposure and Distribution of Basalt Outcrop

Downcutting by the Salmon River and structural deformation are primarily responsible for the spatial distribution of CRB within the area. The most prominent areas of exposure are located along the upper Salmon River from Linny Creek to Rolling Riffle Campground (upper Salmon River exposure), south and west of Arrah Wanna (Arrah Wanna exposure), north of Brightwood, Oregon, (Brightwood exposure), and east of south Boulder Creek, (Salmon River quarry exposure). Relatively small exposures are located along Alder Creek (Alder Creek exposure), and along the south fork of the Salmon River (south fork exposure; see Figure 3). Eighty percent of the exposure utilized by this study for data collection was located within creek bottoms and dry creek beds. 


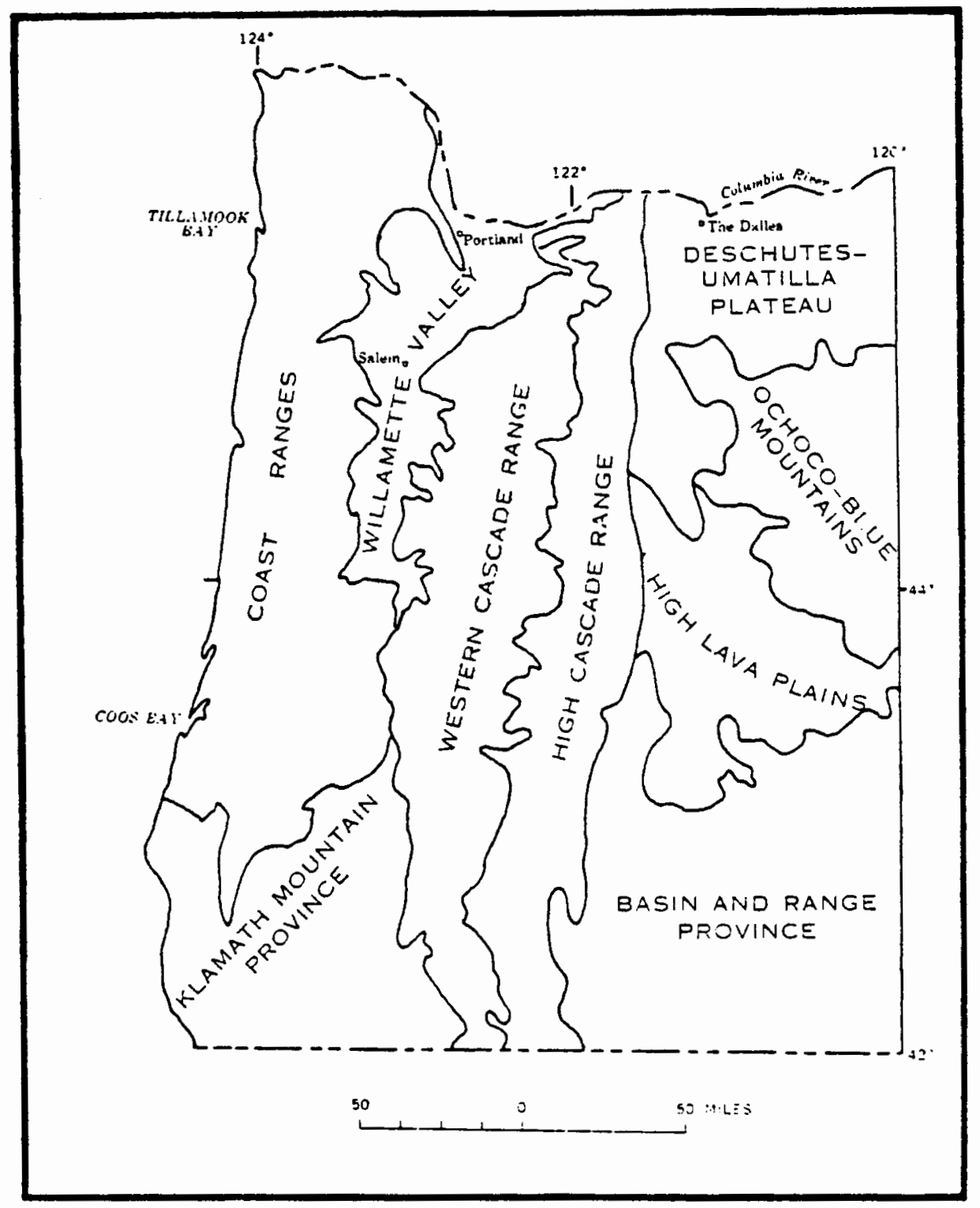

FIGURE 2. Map of the high Cascades, western Cascades and other geologic provinces of Oregon (modified after Peck and others, 1964) 


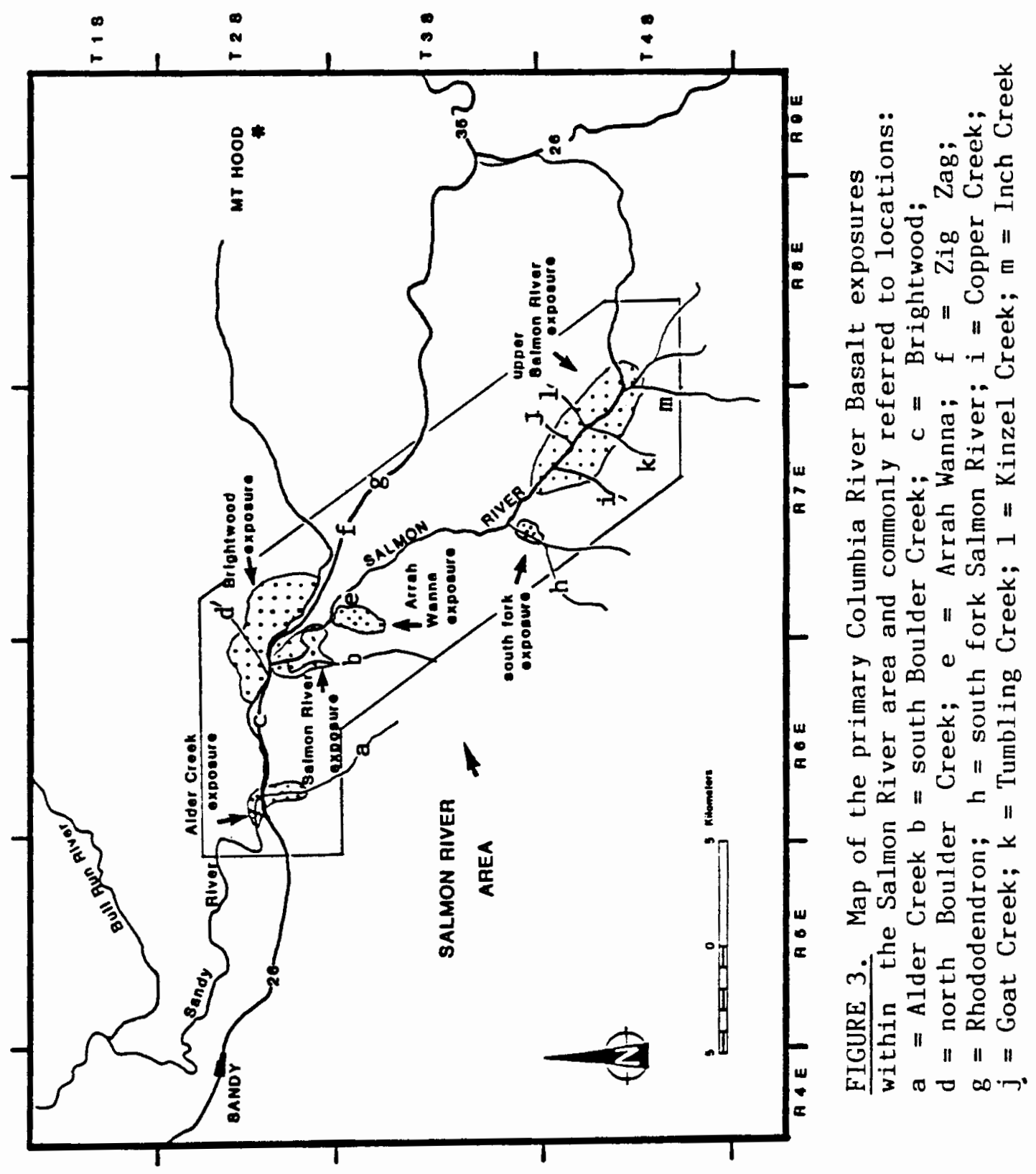


Previous Work in the Salmon River Area

The first known mapping of CRB in the Salmon River area was undertaken during large-scale geologic studies of the Cascade Range (We1ls and Peck, 1961; Peck and others, 1964). Wise (1969) mapped CRB outcrops in the Salmon River area, which he chemically identified as undifferentiated Yakima basalt. More precise identification and correlation of CRB units in western Oregon with those in the Columbia Plateau was undertaken by Beeson and others (1979) and Beeson and Moran, (1979a, b). Beeson's work was followed by accurate accounts of the stratigraphy and structure of the Columbia River basalt within the Clackamas River drainage (Anderson, 1978), in the Hood River Valley, (Timm, 1979), and in the Bul1 Run Watershed (Vogt, 1981). Beeson and Moran (1979b) mapped in reconnaissance the stratigraphy and structure of the Columbia River basalt within the Cascades of Oregon. The Salmon River area was included in this study but map data were not published until 1982 (Beeson and others, 1982).

\section{Regional Geology}

Cascades

The Cascade Range comprises a volcanic province extending from northern California to British Columbia (Wise, 1969). This 48-112 $\mathrm{Km}$ wide belt extends $400 \mathrm{Km}$ between Oregon's northern and southern borders (Peck and others, 1964). It is commonly divided into the Western Cascades (to the west) and the High Cascades (to 
the east; Baldwin, 1981) (See Figure 2). The older Western Cascades are composed of flows, pyroclastics, and volcaniclastics ranging in age from late Eocene to late Miocene. They form the more maturely dissected gradual western slope, which is bounded to the west in northern Oregon by the Willamette Valley (Peck and others, 1964). The High Cascades consist of andesitic flows and related volcaniclastics extruded onto high plateau basalt. This produced a north-south trending series of Pliocene to Quaternary age composite volcanoes (Wise, 1969) of which Mt. Hood, Mt. Jefferson, Three Sisters, and Mt. Mazama are the most distinguished. These peaks define the crest of the High Cascades and form its steep eastern decent. Most peaks above 3,000 ft display evidence of glaciation from the Wisconsin stage of Pleistocene glaciation (Baldwin, 1981).

Prior to middle Miocene time, a large segment of the northern Oregon Cascade Rnge was a structural low. This allowed incursion of basalts from the Columbia Plateau. These flows passed westward through the Cascades to the coastal areas of northern Oregon and southern Washington (Beeson and Moran, 1979a; Beeson and others, 1979). Exposures and drill hole data suggest that the paleo-tectonic low extended from the present day Columbia River to the Clackmas River drainage. This feature was eventually filled by Cascadian volcanism (Beeson and others, 1979a, 1979b; Priest, 1982b). 
Columbia River Basalt Group

The middle to late Miocene tholeiitic flood basalts that form the dominant lithology of the Columbia Plateau are referred to as the Columbia River Basalt Group (CRBG; Swanson and others, 1979). These highly voluminous flows issued from northwesttrending fissure zones (Waters, 1962; Taubeneck, 1970; Swanson and others, 1975) located in the eastern Columbia Plateau between 6 and $16 \mathrm{~m}$. y. ago (Holmgren, 1970). These low-viscosity flows spread over 161,000 sq km (Terry Tolan, personal communication, 1986) of northern Oregon, southeast Washington, and eastern Idaho (Figure 4) and averaged one flow every ten thousand years (Waters, 1962; Baski and Watkins, 1973; McKee and others, 1977). As much as $99 \%$ of the total volume of CRB may have been extruded between 13.5 and $16 \mathrm{~m}$. y. ago (McKee and others, 1977). The thickest accumulations of CRB occur in central areas of the Columbia Plateau (>3.2 km in drill hole RHS-1, Washington; Reidel and others, 1982). CRB that occurs in western Oregon is restricted to the Yakima Basalt Subgroup with an average thickness of $550 \mathrm{~m}$ in the Cascades (Beeson and Moran, 1979a).

\section{Regional Yakima Basalt Subgroup Stratigraphy}

The history of the stratigraphy of the CRB will be dealt with here as an aid to the geologic understanding of this report with respect to the Yakima Basalt Subgroup of the Columbia River Basalt Group. Russell (1901) used the term "Columbia River 




FIGLRE 4. Map showing the extent of the Columbia River Basalt Group (modified after Beeson and others, 1985) 
basalt" to describe basaltic flows in the Pacific Northwest. Recognizing the need for stratigraphic subdivision of such a large sequence of flows, Smith (1901) applied the name Yakima basalt to flows exposed along the Yakima River, Washington. Rapid development of CRB stratigraphy began with Waters' (1961) single break between the older Picture Gorge and the Yakima basalt, based on stratigraphic, chemical, and petrograhpic techniques. Division of Russel's "Columbia River basalt" based on petrography, paleo-magnetics, chemistry, (major and trace element), and lithology continued most notebly by the works of Bond (1963), Bingham and Grolier (1966), Swanson (1967), Ledgerwood and others (1973), Wright and others (1973), Hooper (1974), Schmincke (1967) and Asaro and others, (1978). A formal revision of stratigraphic nomenclature for the Columbia River Basalt Group was proposed by Swanson and others (1979) and accepted by the United States Geologic Survey (USGS). This has become the standard of usage and will be adhered to throughout this text (Figure 5). Currently, the most reliable method for identifying CRBG stratigraphy is through trace element and major oxide composition (Osawa and Goles, 1970; Wright and others, 1973; Siems and others, 1974; Uppuluri, 1974; Beeson and others, 1975, 1976; and Beeson and Moran, 1979a, b; Beeson and others, 1985). Trace element stratigraphy of CRB allows correlation of individual flow units throughout their exposure. Paleomagnetic units (magnetozones) may be used in conjunction with geochemical units to aid stratigraphic control. This is especially useful 




FIGURE 5. Stratigraphy of the Columbia River Basalt Group, $\mathrm{N}=$ normal magnetic polarity; $\mathrm{R}=$ reversed magnetic polarity; $\mathrm{T}=$ transitional magnetic polarity; $\mathrm{E}=$ excursional magnetic polarity, (after Swanson and others, 1979, and modified by Beeson and others, 1985) bar on right indicates units exposed in the Salmon River area. 
with the chemically homogenous flows of the Grande Ronde Basalt. Flows of the Columbia River Basalt Group that exist within the Salmon River area are restricted entirely to the Grande Ronde Basalt and Wanapum Basalt formations of the Yakima Basalt Subgroup.

Grande Ronde Basalt

Grande Ronde Basalt is the most abundant chemical type comprising $85 \%$ of the total Columbia River Basalt Group volume (Reidel and others, 1982) with extensive distribution (Figure 6). Thickness varies locally in response to pre-basalt topography with overall thinning away from the Columbia Plateau. The thickest known section occurs in the central Columbia Plateau in the Rattlesnake Hills drill hole number one (RHS-1; Reidel and others, 1982). The total CRBG thickness at this location was greater than $3.2 \mathrm{~km}$ and was largely comprised of Grande Ronde Basalt. The basal contact of the Grande Ronde Basalt conformably overlies Imnaha basalt flows at the Washington-Oregon-Idaho border (Holden and Hooper, 1976) and is interfingered with Picture Gorge Basalt where the Blue Mountains do not intervene. The Prinville chemical type is not a formal subdivision of the Columbia River Basalt Group (Swanson and others, 1979). It was originaly thought to consist of 13 flows at its type section near the Prineville Dam (renamed Bownan Dam) where an accumulation of $240 \mathrm{~m}$ was noted (Uppuluri, 1974). Reevaluation of the type section by Smith (1986) indicates that six flows are 


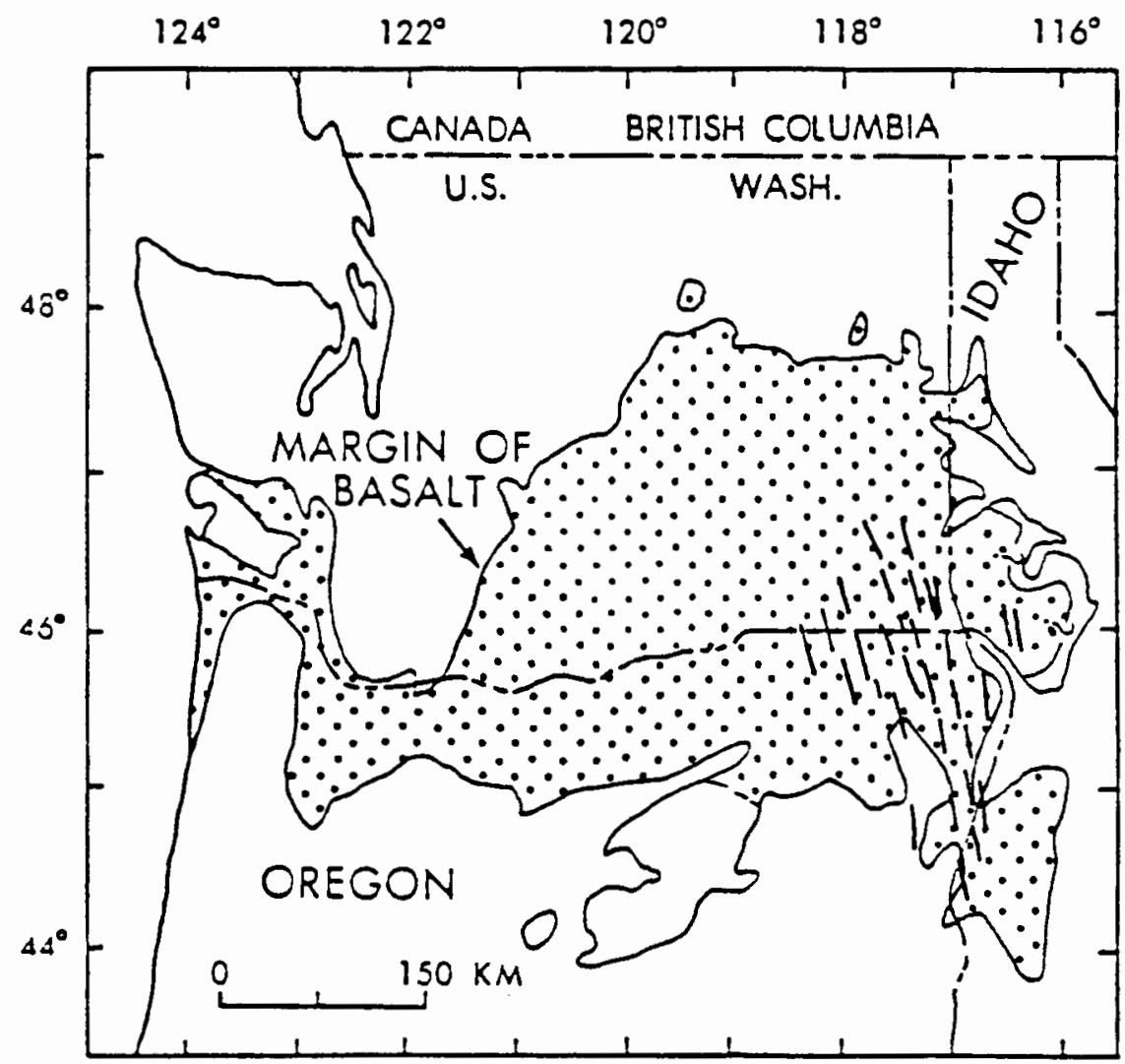

GRAIDE RONDE BASALT $\because 9$

FIGLRE 6. Map showing the extent of Grande Ronde Basalt (modified after Beeson and others, 1985) 
present there and that eight flows exist throughout northwestern and central Oregon. The discrepancy was explained by Uppuluri's duplication of the section. The magnetostratigraphy for the redefined type section is (oldest to youngest) reversed/normal /norma1/normal/reversed/normal (Smith, 1986). This sequence is unconformably underlain and overlain by the John Day Formation and Pliestocene-Pliocene olivine basalt flows, respectively. Flows of the Prineville chemical type may be interbedded with Grande Ronde Basalt (Nathan and Fruchture, 1974; Beeson and Moran, 1979a). This relationship was noted in the Clackamas River drainage (Anderson, 1978).

Vantage Member

Vantage Sandstone Member of the Yakima Basalt Subgroup was the first term used to describe the compositionly variable tuffaceous sandstone interbed between the Grande Ronde and Wanapum Basalt (Mackin, 1961; Bingham and Grolier, 1966). Current usage suggested by Schmincke (1967) places the interbed in the Ellensburg Formation with which it grades laterally becoming non-distinguishable. Because of its variable lithology, it is now referred to as the Vantage Member of the Ellensburg Formation (Swanson and others, 1979). The Vantage Member interbed provides a distinct marker between Grande Ronde Basalt and Wanapum Basalt. 
Wanapum Basalt

Wanapum Basalt flows are the dominant surface lithology of the Columbia River Basalt Group in the Columbia Plateau and in Western Oregon (Swanson and Wright, 1981). The origin of Wanapum flows has been traced to dikes of the same chemical composition located in northeast Oregon, southeast Washington, and western Idaho (Swanson and others, 1975, 1979). The structurally irregular surface of the Grande Ronde Basalt influenced the flow distribution of the Wanapum Basalts throughout the Cascades (Beeson and Moran, 1979b; Beeson and others 1985). The four petrographic and paleomagnetic units recognized within the Wanapum Basalt are (oldest to youngest) Eckler Mountain Member, Frenchman Springs Member, Roza Member, and Priest Rapids Member. Only flows of the Frenchman Springs Member have been found in the Salmon River area and the Clackamas River drainage to the south (Anderson, 1978; Beeson and Moran, 1979b). Its distribution throughout Oregon and Washington is shown on Figure 7.

\section{Procedure and Methods}

Field Work

Approximately $26 \mathrm{sq} \mathrm{km}$ was mapped within an area of $300 \mathrm{sq}$ $\mathrm{km}$. Data were plotted at a scale of $1: 24,000$ on a base map constructed from the Cherryville and High Rock 15 minute topographic quadrangles and from the Rhododendron, Government Camp, and Hickman Butte $71 / 2$ minute topographic quadrangles. 


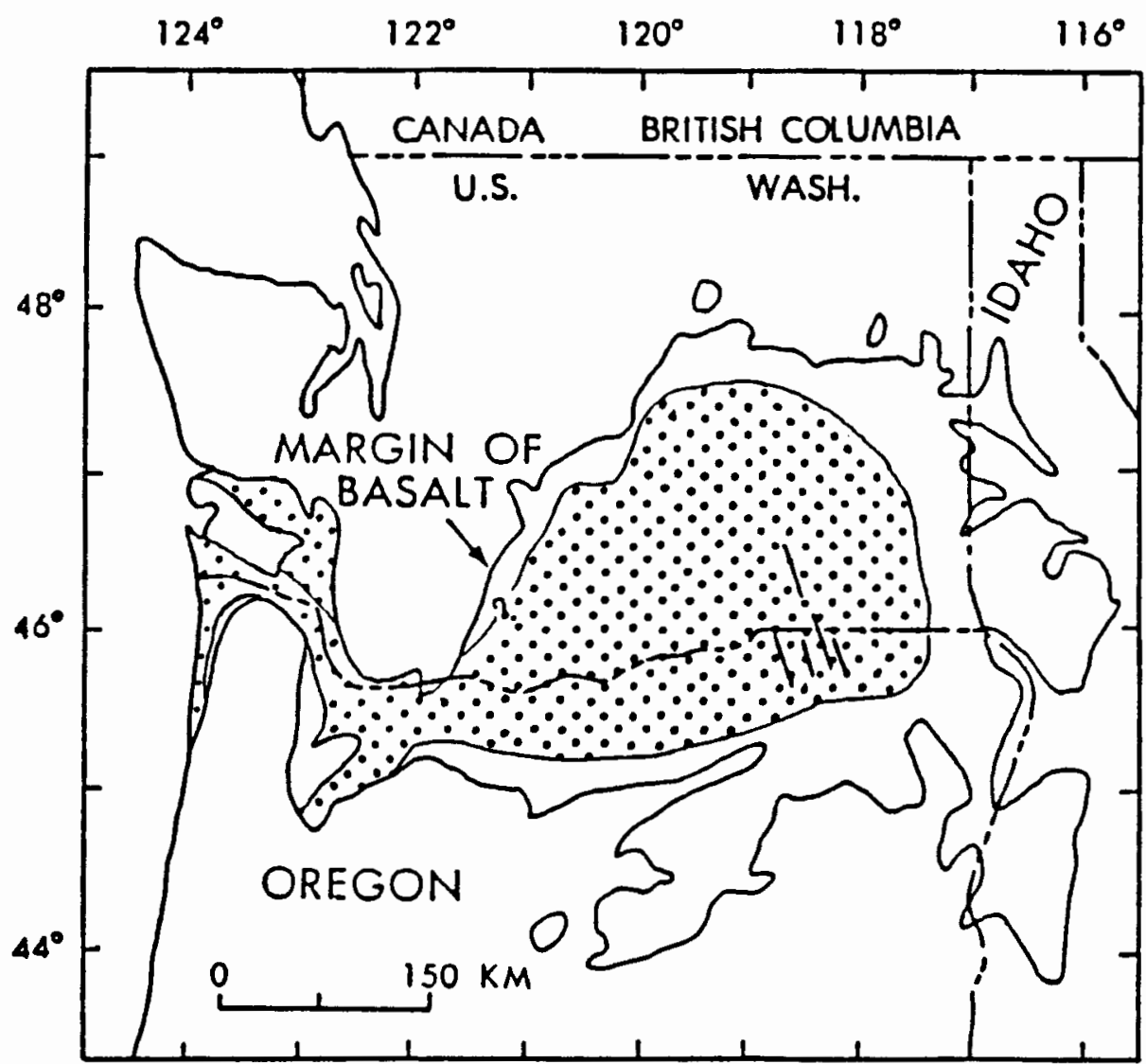

FRENCHMAN SPRINGS MEMBER $\because \because$

FIGURE 7. Map showing the extent of Frenchman Springs basalt (modified after Beeson and others, 1985) 
Field work was completed in 45 man-days between July and September 1984 and included mapping contacts of individual flows and detailed stratigraphic sampling for chemical analysis. Outcrops were examined for structures including attitudes of individual flow contacts, joints, breccia zones, horizontal cooling joints, and lineations (slickensides). Several measurements were taken of individual structures to increase the reliability of the data. Instruments used for plotting and section measuring included a Brunton pocket transit and a 15,000 $\mathrm{ft}$ Thommen pocket altimeter graduated at $20 \mathrm{ft}$ intervals. Limited exposure confined data gathering primarily to stream beds and drainage channels where fresh samples could be taken and contacts were discernable. Samples were generally taken from the colonnade, which was of ten the only suitably exposed portion of the flow. Complete coverage of the study area with color aerial photographs was provided by Marvin H. Beeson. Aerial photographs were primarily used to locate good outcrop and orient traverses but were sometimes useful for discerning structures.

Laboratory Work

Preliminary major oxide analysis of 24 basalt samples was performed by Peter Hooper at Washington State University using $x-$ ray fluorescence spectrometry (XRF). Results of major oxide analyses were available during the field season providing reassurance and direction for continued work through stratigraphic control of four sections consisting of three or 
more flows. Another 70 samples were analyzed by XRF at the end of the field season. Trace element compositions for 72 samples were determined by Instrumental Neutron Activation Analysis (INAA) adhering to the practices of Marvin $\mathrm{H}$. Beeson (personal com munication). Sample locations are plotted on Appendices Ml and M2; chemical types corresponding to sample locations are indicated on Appendix M3.

Irradiation of the samples was conducted on April 16, 1985 at Reed College in Portland, Oregon, with a Triga model thermal neutron reactor. Two USGS standards were included in the experiment. BCR-1 was the standard used for basalt but contains a relatively low chromium (Cr) concentration (17.6 ppm; Flanagan, 1976). PCC-1, which is the standard for dunite, was included because of its extremely high $\mathrm{Cr}$ concentration (2730.0 ppm; Flanagan 1976). This increases the accuracy of the determined $\mathrm{Cr}$ content in the sample unknowns. $\mathrm{Cr}$ content is critical when distinguishing between chemical units of the Frenchman Springs basalt (Beeson and others, 1985). 


\section{CHAPTER II}

\section{SALMON RIVER AREA BASALT STRATIGRAPHY}

At least $461 \mathrm{~m}$ of Columbia River basalt flowed into the Salmon River area within a period of $2.7 \mathrm{~m}$. y. The combined section consists of 15 flows (Figure 8) but typically only four to eight flows are exposed in a single section. The flows were classified primarily by chemical composition, but stratigraphic position and hand specimen appearance were useful in some instances. The entire section is contained within two formations of the Yakima Basalt Subgroup: the Grande Ronde Basalt and the Wanapum Basalt. Grande Ronde Basalt is chemically distinguished from other $\mathrm{CRB}$ by its lower $\mathrm{FeO}$ and higher $\mathrm{SiO} 2$ relative to $\mathrm{MgO}$ (Swanson and others, 1979). The Grande Ronde Basalt section consists of two chemically distinct units referred to informally as low-MgO, and high-MgO with a third interfingered Prineville chemical type. The Grande Ronde Basalt is also divided by paleomagnetism into four magnetozones (Hooper and others, 1979; Swanson and others, 1979; see Figure 5). These stratigraphic breaks (N1, R1, N2, R2) are useful to magneto-correlation and aid general stratigraphy (Swanson and Wright, 1976; Choiniere and Swanson, 1979). Reversals in magnetic polarity are useful for correlating mappable magnetostratigraphic horizons. Except for a very limited exposure of the $N 2 / R 1$ horizon south of 


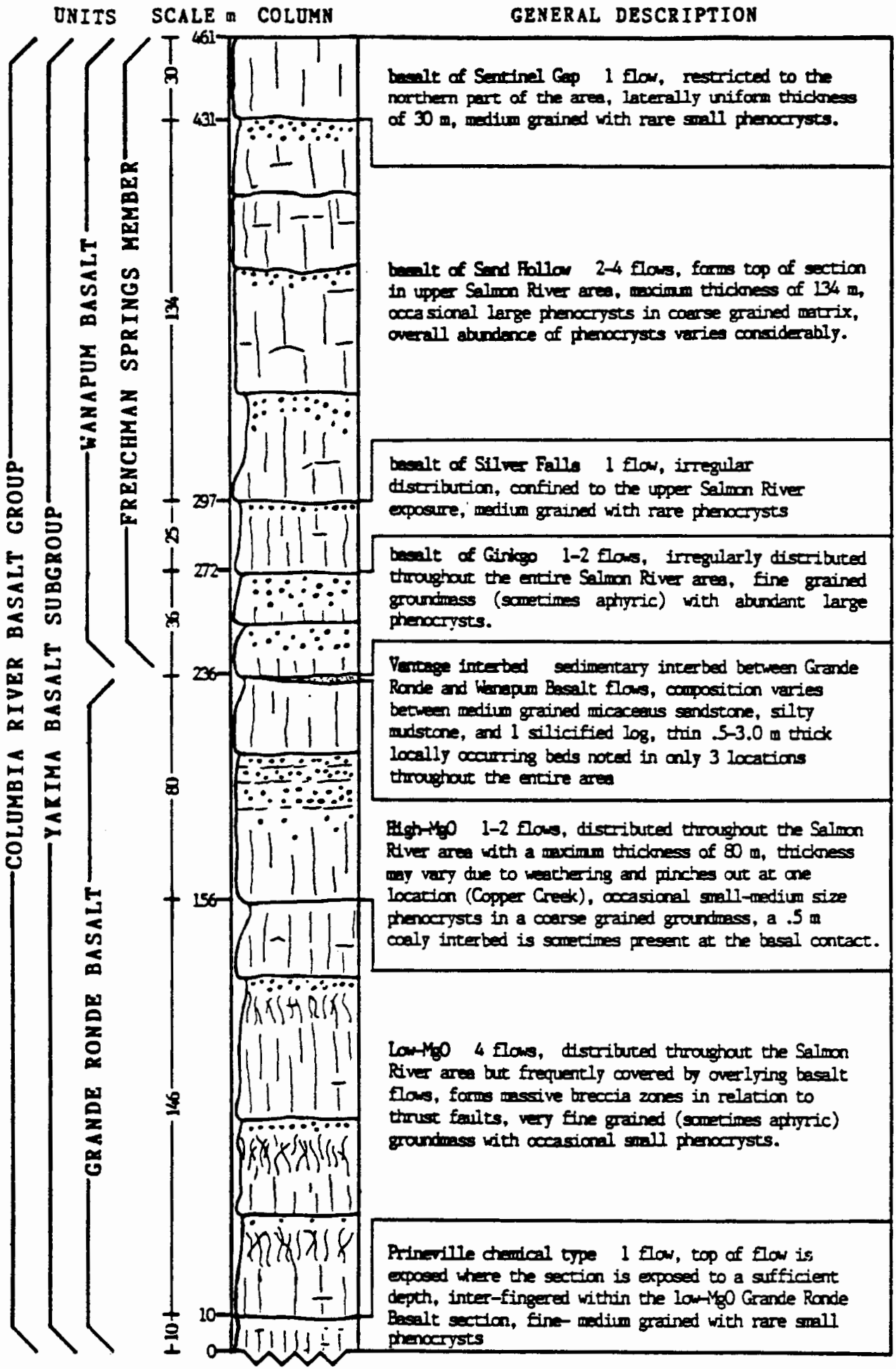

FIGURE 8. Composite stratigraphic columnar section of the Columbia River basalt in the Salmon River area, Oregon 
Copper Creek, the entire exposed Grande Ronde basalt section accumulated during a single (N2) magnetic event (Beeson, unpublished).

Four chemically distinct units are recognized in the Wanapum Basalt section including the basalt of Ginkgo, the basalt of Silver Falls, the basalt of Sand Hollow, and the basalt of Sentinel Gap. Grande Ronde Basalt is ubiquitious in the Salmon River area unlike Wanapum flows some of which display irregular and nonuniform distribution.

\section{Grande Ronde Basalt}

Distinctly lower $\mathrm{FeO}, \mathrm{P} \mathrm{O}$, and $\mathrm{TiO}$, and higher SiO 252 (Table I) and lower Eu content (Table II) readily differentiates the Grande Ronde Basalt from flows of the Wanapum Basalt. The section is further divided into the above mentioned $10 \mathrm{w}-\mathrm{MgO}$ and high-MgO chemical types on the basis of less than $4.00 \% \mathrm{MgO}$ (1ow$\mathrm{MgO}$ ) and greater than $4.00 \% \mathrm{MgO}$ (high-MgO). The $\mathrm{CaO}$ content is also distinctive with $<8.00 \% \mathrm{CaO}$ characterizing low-MgO basalt and $>8.00 \% \mathrm{CaO}$ characterizing high-MgO basalt. Several other elements support this chemical break within the Grande Ronde Basalt section including $\mathrm{Th}$, La, $\mathrm{Ce}, \mathrm{Cr}, \mathrm{Sc}$, (Table II). 
TABLE I

AVERAGE MAJOR-OXIDE COMPOSTITON FOR DISTINCT CHEMTCAL TYPES

\begin{tabular}{|c|c|c|c|c|c|c|c|c|c|c|}
\hline EIEMENT & Si & $\mathrm{Al}$ & $\mathrm{Ti}$ & *Fe & M & $\mathrm{Ca}$ & $\mathrm{Mg}$ & $\mathrm{K}$ & $\mathrm{Na}$ & $\mathrm{P}$ \\
\hline CHEMICAL TYPE & & \multicolumn{9}{|c|}{ WHOLE ROCX WEIGHT PERCENT OF ELEMENT IN OXIDE FORM } \\
\hline \multicolumn{11}{|c|}{$\begin{array}{l}\text { FRENCHMAN SPRINGS MEMBER } \\
\text { (WANAPUM BASALT) }\end{array}$} \\
\hline \multicolumn{11}{|l|}{ basalt of } \\
\hline SENTINEL GAP $/ 8$ & 52.39 & 14.26 & 3.12 & $12 . \infty 0$ & 0.23 & 8.01 & 4.15 & 1.08 & 2.25 & 0.52 \\
\hline \#范 & 0.27 & 0.11 & 0.05 & 0.34 & 0.02 & 0.21 & 0.28 & 0.14 & 0.20 & 0.00 \\
\hline \multicolumn{11}{|l|}{ basalt of } \\
\hline SAND HOLOW / 26 & 52.57 & 14.58 & 3.02 & 11.53 & 0.21 & 8.11 & 4.28 & 1.00 & 2.20 & 0.50 \\
\hline & 0.71 & 0.27 & 0.06 & 0.85 & 0.02 & 0.53 & 0.36 & 0.42 & 0.17 & 0.01 \\
\hline \multicolumn{11}{|l|}{ basalt of } \\
\hline SILVER FALLS /6 & 52.20 & 14.28 & 3.14 & 12.30 & 0.22 & 8.12 & 4.22 & 0.87 & 2.13 & 0.53 \\
\hline \#\# & 0.43 & 0.24 & 0.07 & 0.31 & 0.01 & 0.25 & 0.18 & 0.39 & 0.06 & 0.01 \\
\hline \multicolumn{11}{|l|}{ basalt of } \\
\hline  & 0.43 & 0.17 & 0.05 & 0.61 & 0.03 & 0.18 & 0.30 & 0.18 & 0.13 & 0.02 \\
\hline \multicolumn{11}{|c|}{ GRANDE RONDE BASALT } \\
\hline HIGH-MgO / 20 & 53.84 & 15.05 & 2.02 & 9.86 & 0.21 & 8.58 & 4.84 & 0.81 & 2.50 & 0.29 \\
\hline ***: & 0.28 & 0.16 & 0.07 & 0.33 & 0.01 & 0.31 & 0.28 & 0.21 & 0.16 & 0.02 \\
\hline LOW-MOO /21 & 55.37 & 14.95 & 2.19 & 10.23 & 0.20 & 7.12 & 3.66 & 1.37 & 2.58 & 0.32 \\
\hline 㟋 & 0.54 & 0.24 & 0.11 & 0.73 & 0.01 & 0.26 & 0.02 & 0.30 & 0.19 & 0.01 \\
\hline PRINEVILE /1 & 51.89 & 15.11 & 2.75 & 10.04 & .22 & 8.12 & 4.24 & 1.38 & 2.66 & 1.22 \\
\hline
\end{tabular}

* Fe content listed is $\mathrm{FeO}$; $\mathrm{Fe} 203$ assumed to be $2.00 \%$

** Standard deviation of calculated averages \pm 1 sigma

$/ \mathrm{n}=$ Number of samples used to calculate average 


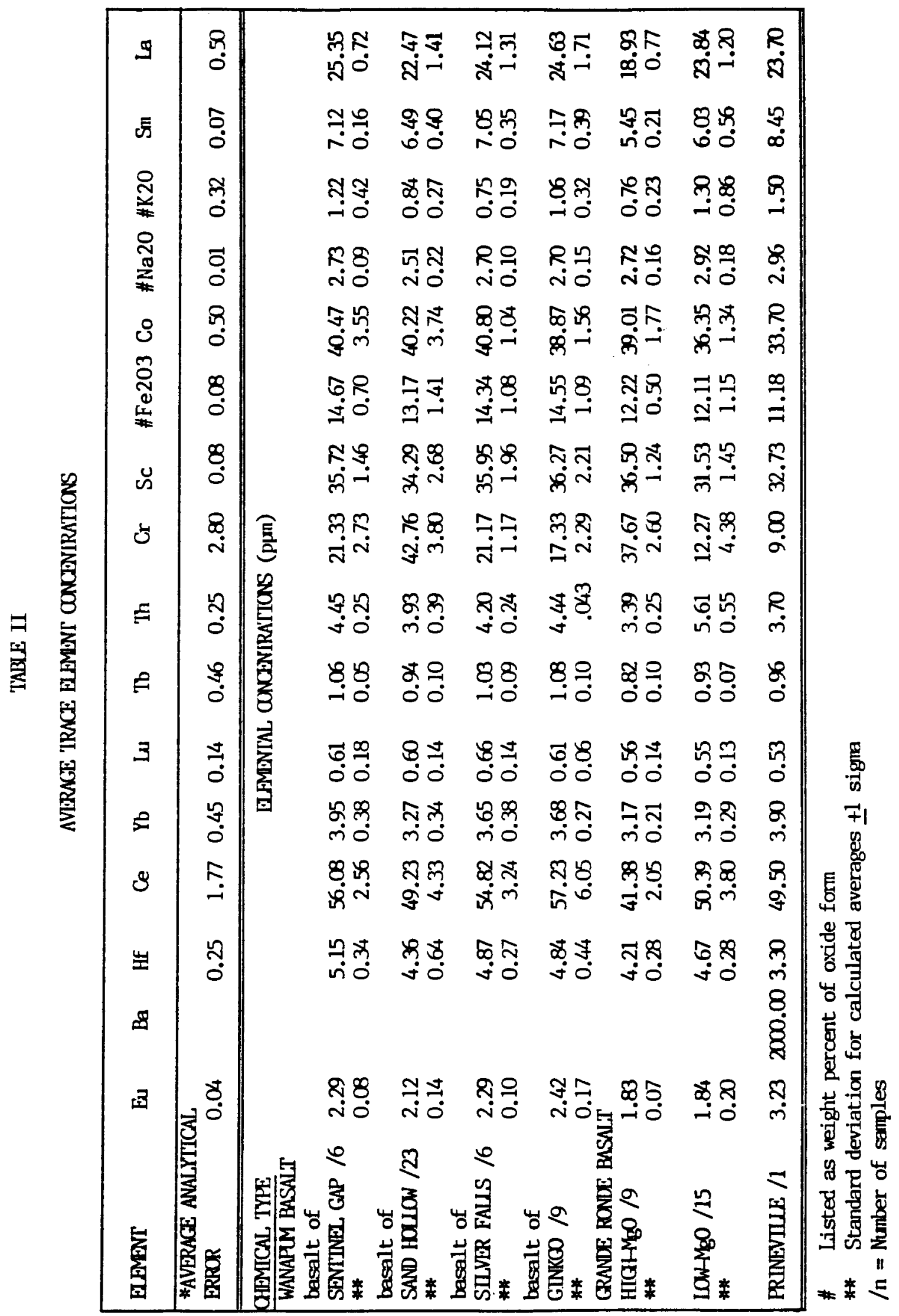


Low-MgO Grande Ronde Basalt

A maximum section of four flows totaling $146 \mathrm{~m}$ is exposed in the upper Salmon River area southeast of the mouth of Copper Creek (N.E.1/4, sec. 1, T. 4 S., R. 7 E; Plate 1, map pocket). The basal contact is not exposed but probably overlies Oligocene (?) volcaniclastics of the Eagle Creek Formation as noted in the Old Maid Flat area $1.2 \mathrm{~km}$ to the northeast determined by drill hole data (Priest 1982b). The thickness of individual flows is laterally uniform. low-Mg0 flows are texturally very fine grained and occasionally phyric with an average flow thickness of $39 \mathrm{~m}$. In the Salmon River quarry, the Brightwood quarry, and the old county quarry the low-MgO section is capped by a thin, $6 \mathrm{~m}$ thick flow. This flow has textural similarities with the top of the low-MgO section near Oregon City referred to informally as Winter Water (Beeson, personal communication). Complete chemical data for low-MgO samples are shown on Appendices A and B.

High-MgO Grande Ronde Basalt

A carbonaceous, coaly, interbed $0.5 \mathrm{~m}$ thick provides a stratigraphic marker between the low-MgO section and the base of the overlying high-MgO section. This interbed is visible in the northern part of the Salmon River area at the Salmon River, old county, and new Brightwood quarry locations. but is absent or not discernable in the upper Salmon River area. The high-MgO section is up to $80 \mathrm{~m}$ thick and consists of one to two flows. These flow units thin laterally and pinch out in the vicinity of Copper 
Creek to the west of the Salmon River but are otherwise continuous forming the top of Grande Ronde Basalt section. This high-MgO is distinctly coarse grained with rare phenocrysts providing megascopic distinction from the underlying low-MgO basalt. The phenocrysts in high-MgO basalt are consistently smaller than the typical Frenchman Springs phenocryst and are less abundant. Good exposures of high-MgO flows reveal a well developed basal colonnade forming up to half the flow thickness with a multi-tiered vesicular flow top that may indicate simultaneous discrete pulses of thin flow sheets within a single cooling event. Complete chemical data for high-Mg0 samples is shown on Appendices C and D.

Prineville Chemical Type

Chemical differences in the major-oxide and trace element composition of the Prineville chemical type is the most discernable difference between the lithologically and texturally similair low-Mg0 basalt. As seen in Tables I and II, the elemental abundance of $\mathrm{Ba}(2,000 \mathrm{ppm})$ and $\mathrm{P} \mathrm{O}(1.22 \%)$ are each 25 singly significant to distinguish the Prineville chemical type from other CRB flows. Other well defined compositional differences include SiO and $\mathrm{TiO}$, (Table I) and Sm (Table II). 22

Recent work on the stratigraphy of the Prineville chemical type at its type locality and throughout central and northwestern Oregon has determined that two chemically distinct varieties exist on the basis of $\mathrm{KO}$ and SiO concentration (Smith, 1986). 
$\mathrm{K} \mathrm{O}$ is the key element that allows division of Prineville flows 2

into (1) low-K $\mathrm{O}_{2} / \mathrm{low}_{2} \mathrm{SiO}_{2}$, and (2) high-K 2 /high-SiO 2 (Table

III). The type locality consists entirely of low-K $0 /$ low-SiO

252

chemical type but is overlain by high-K 0 /high-SiO less than 25 $\mathrm{km}$ to the north (Smith, 1986).

$$
25 \quad 2
$$

The Prineville chemical type is exposed along a very

limited segment of the Salmon River south of the mouth of Copper Creek and is interfingered with Grande Ronde Basalt. At this location the upper $6 \mathrm{~m}$ of the flow is exposed and represents the maximum penetration into the $\mathrm{CRB}$ section in the Salmon River area. This flow is a low-K 0 type $(1.38 \%$ ) as seen on Table III, but its polarity remains undetermined.

Two Prineville flows were mapped in the Clackamas River drainage, and a second flow is likely to exist in the Salmon River area at depth. The top of the Prineville section in the Salmon River area is stratigraphically beneath four low-MgO flows; similar to its position in the Clackamas River drainage where both Prineville flows have reversed polarity and are immediately beneath the $\mathrm{N} 2 / \mathrm{R} 2$ horizon. The similarity in chemical type and stratigraphic position between these two areas, with respect to the Prineville basalt, suggests that the N2/R2 horizon is situated near the top of the Prineville flow in the Salmon River area. A low-K O Prineville chemical type with 2

normal polarity (determined from side core sample; Beeson, personal communication) is also noted in the 01d Maid Flat area to the north (Priest, 1982b; see Table III). 
TABLE III

COMPARISON OF THE SAIMON RTVER AREA PRTEEUILE

OHEMCAL TYPE WIIH OTHER AREAS

\begin{tabular}{|lrrrrrrr|}
\hline & $1(10)$ & $2(10)$ & $3(15)$ & $4(1)$ & $5(1)$ & $6(1)$ & $7(1)$ \\
$\mathrm{SiO2}$ & 54.49 & 51.22 & 50.54 & 51.27 & 51.89 & 51.18 & 51.13 \\
$\mathrm{TiO2}$ & 2.51 & 2.78 & 2.67 & 2.81 & 2.75 & 2.62 & 2.76 \\
$\mathrm{~A} 203$ & 15.36 & 14.50 & 13.59 & 14.58 & 15.11 & 14.85 & 14.99 \\
$\mathrm{FeO}$ & 10.55 & 13.37 & 13.38 & 13.07 & 13.11 & 13.21 & 12.31 \\
$\mathrm{M} 0$ & 3.25 & 4.22 & 4.35 & 3.99 & 4.24 & 4.58 & 3.36 \\
$\mathrm{CaO}$ & 6.08 & 7.89 & 7.96 & 8.07 & 8.12 & 8.08 & 9.16 \\
$\mathrm{Na} 20$ & 2.99 & 2.68 & 3.29 & 2.76 & 2.66 & 3.01 & 2.86 \\
$\mathrm{~K} 20$ & 3.37 & 1.86 & 1.98 & 1.68 & 1.38 & 1.65 & 1.22 \\
$\mathrm{P} 205$ & 1.17 & 1.24 & 1.36 & 1.24 & 1.22 & 1.21 & 1.46 \\
$\mathrm{M} 0$ & 0.23 & 0.24 & 0.24 & 0.25 & 0.22 & 0.25 & 0.26 \\
& & & & & & & \\
$\mathrm{Ba}$ & 2108.00 & 2159.00 & 1987.00 & nd & 2000.00 & 2500.00 & 2400.00 \\
$\mathrm{Sc}$ & 33.00 & 37.00 & 36.00 & nd & 32.73 & 39.10 & 36.40 \\
\hline
\end{tabular}

$(n)=$ number of samples

nd = no data or data not available

1. Central Oregon; average composition of high-K20/high-SiO2 Prineville chemical-type basalt (Smith, 1986).

2. Type locality (Bownan Dam); average camposition of low-K2O/low-SiO2 Prineville chemical-type basalt (Smith, 1986).

3. Type locality (Bownan Dam); average composition of low-K2O/low-SiO2 Prineville chenical-type basalt (Uppulurri, 1974).

4. Pelton Dan; compositon of the first Prineville chemical-type basalt flow (sec. 18, T. 10 S., R. 12 E.; Smith, 1986).

5. Salmon River area; composition of the Prineville chemical type basalt flow (N.W.1/4, S.W.1/4, sec. 1, T. 4 S., R. 7 E.; this study).

6. Clackamas River area; composition of the Prineville chemical-type basalt (Anderson, 1978).

7. Old Maid Flat area; composition of the Prineville chemical-type basalt near Mt. Hood, Oregon (drill hole aff-7; Priest, 1982b). 
A northwest trend of five documented exposures of the Prineville low-K 0 chemical type is projected between the Salmon 2

River area and the Bowman Dam (formerly Prineville Dam) type locale (Figure 9). In comparing chemical data from the Salmon River area with these locations, a striking match was noted with the low-K 0 chemical type at the Pelton Dam (\#LS1, S.W.1/4, sec. 18, T. $10 \mathrm{~S} .$, R. $12 \mathrm{E}$; ; see Table III). Considering the trend of Prineville type exposures and the marked chemical simularity, I suggest that continuity of this horizon exists between the Pelton Dam and the Salmon River area. Magnetic polarities in the Clackamas River area (reversed) and at the Pelton Dam (normal) are in direct conflict with each other and therefore cannot both be correlated with the Salmon River area even though compelling arguments may support this. Paleo-magnetic correlation within the Prineville section has met with little success as discussed by Smith (1986). This situation should improve with continued stratigraphic refinement of Prineville exposures through geochemistry, laboratory measured paleo-magnetics, and more detailed and extensive mapping.

The absence of Prineville chemical type in the Hood River Valley (Timm, 1979) and in the Bull Run drainage (Vogt, 1981) indicates its termination south of these areas just north of the 01d Maid Flat area. Complete chemical data for the Prineville chemical type in the Salmon River area is shown in Tables I, II, and III. 


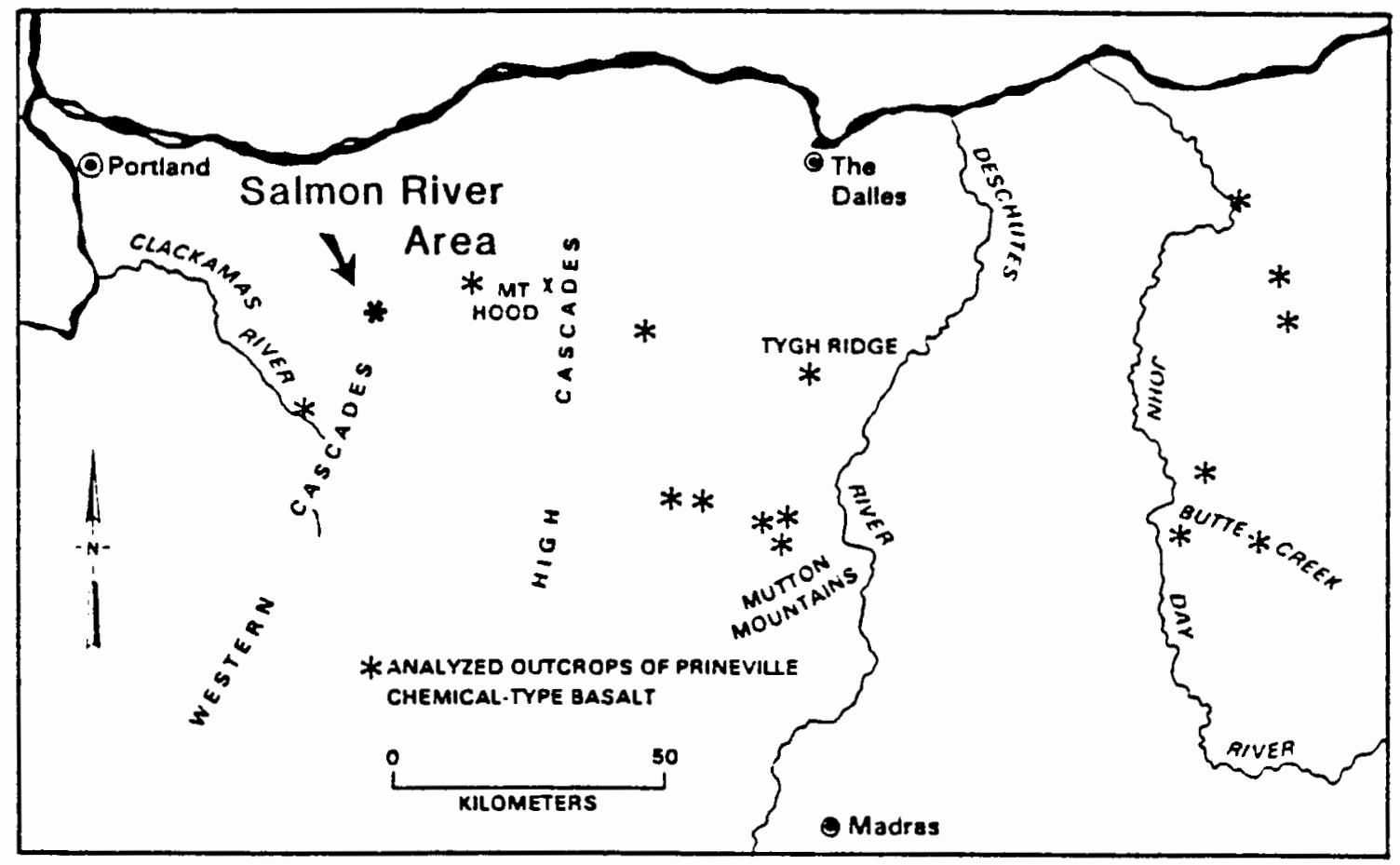

FIGURE 9. Locations of documented analyses of the Prineville chemical type in central and northwestern Oregon, (modified from Smith, 1986) 


\section{Vantage Interbed}

The Vantage interbed is widely recognized in the CRB section where it is exposed in the Columbia Plateau and western Oregon. This horizon marks the boundary between the top of the Grande Ronde Basalt and the base of Wanapum Basalt. It commonly consists of up to $30 \mathrm{~m}$ of volcaniclastic sedimentary material in the Cascades and western Oregon (Anderson, 1978; Timm, 1979; Vogt, 1981).

The Vantage interbed as seen in the Salmon River area is laterally discontinuous with locally occurring outcrops. Despite widespread exposure of the vantage horizon, evidence of interbedded material was found in only three locations.

One exposure, that most typified the Vantage interbed as described at other locations in the Cascades and western Oregon, was located along south Boulder Creek (S.W.1/4, N.W.1/4, sec. 36, T. 2 S., R. 6 E.) within the Salmon River quarry exposure (Plate 1). Here a maximum of $1.3 \mathrm{~m}$ of finely bedded micaceous, medium grained sandstone lies interbedded between high-MgO Grande Ronde Basalt (below) and the basalt of Ginkgo (above). The extent of this interbed is very limited and cannot be traced beyond the 15 $\mathrm{m}$ wide outcrop exposed in the west side of the creek bed.

Several exposures of the Vantage horizon northeast of this point along the Salmon River lacked visible evidence of its continuation in that direction.

Another well exposed segment of the Vantage horizon crops out at the 2,520 ft elevation along the southern extent of the 
Arrah Wanna exposure (N.E.1/4, N.W.1/4, sec. 7, T. 3 S., R. 7 E.). Here the contact is void of sedimentary material and was identified by the remains of a silicified $\log$ incorporated in the base of the overlying flow (basalt of Ginkgo). The contact is exposed crossing a creek bed for a lateral distance of no more than 15-20 m. The underlying flow of low-Mgo Grande Ronde Basalt appeared to have a vesicular flow top typical of noneroded horizons.

A third outcrop of the Vantage interbed exposed along Tumbling Creek just above its mouth (S.E.1/4, S.W.1/4, sec. 7, T. 4 S., R. 8 E.) can be traced laterally less than $3 \mathrm{~m}$ and consists of $0.5 \mathrm{~m}$ of silty mudstone. This horizon is exposed upstream along Tumbling Creek where no interbedded material is present. The term "Vantage horizon" is more descriptive of this stratigraphic boundary in the Salmon River area because of the predominant lack of interbedded material. The Vantage interbed is exposed as thin, locally-occurring beds with highly variable composition and environments of deposition. This horizon represents a period of time dominated by the lack of CRB flows into the area and not the processes forming the sedimentary Vantage interbed as seen in the Columbia Plateau.

\section{$\underline{\text { Frenchman Springs Member }}$}

The Frenchman Springs Member consists of six regionally distinctive stratigraphic units (Beeson and others, 1985) based 
on compositon, stratigraphic position, paleomagnetic data and to a lesser degree plagioclase phenocryst/glomerocryst abundance. The informal terminology of the Frenchman Springs units proposed by Beeson and others (1985) were used by this study. The correlation of these terms with previously defined units of the Frenchman Springs Member is shown in Figure 10. Of the six regionally distinctive Frenchman Springs units, four have been identified in the Salmon River area. These units are (oldest to youngest) the basalt of Ginkgo, the basalt of Silver Falls, The basalt of Sand Hollow, and the basalt of Sentinel Gap. They were distinguished primarily by chemical composition and stratigraphic position, and to a minor extent by plagioclase phenocryst/glomerocryst abundance. At least eight individual Frenchman Springs basalt flows entered the Salmon River area during Wanapum Basalt time. The average section consists of between two and six flows depending on its relation to structural features. Local stratigraphic thickness varies between 50 and $100 \mathrm{~m}$, but the combined maximum accumulation of Frenchman Springs basalt within the Salmon River area totals $196 \mathrm{~m}$.

Basalt of Ginkgo

The basalt of Ginkgo is a low $\mathrm{Cr}$, high $\mathrm{P}_{2} \mathrm{O}_{5}$ Frenchman Springs unit. The $\mathrm{Cr}$ content in this unit is characteristicaly low and generally $<20$ ppm (commonly $<9$ ppm, see Appendix H) similar only to low-MgO Grande Ronde Basalt from which it is otherwise chemically distinct. As seen in Table II, 


\begin{tabular}{|c|c|c|c|}
\hline $\begin{array}{l}\text { MACKIN } \\
\text { (1961,p.8) }\end{array}$ & $\begin{array}{c}\text { BENTLEY } \\
\text { (1977:, p.361) }\end{array}$ & $\begin{array}{l}\text { BENTLEY AND } \\
\text { CAMPBELL (1983) } \\
\end{array}$ & $\begin{array}{l}\text { Beeson and } \\
\text { others (1985) }\end{array}$ \\
\hline & & & $\begin{array}{l}\text { BASALT OF } \\
\text { LYONS FERRY }\end{array}$ \\
\hline $\begin{array}{c}\text { SENTINEL GAP } \\
\text { FLOW }\end{array}$ & $\begin{array}{l}\text { UNION GAP } \\
\text { FLOWS }\end{array}$ & $\begin{array}{l}\text { FLOWS OF } \\
\text { UNION GAP }\end{array}$ & $\begin{array}{l}\text { BASALT OF } \\
\text { SENTINEL GAP }\end{array}$ \\
\hline $\begin{array}{l}\text { SAND HOLLOW } \\
\text { FLOW }\end{array}$ & $\begin{array}{l}\text { KELLEY HOLLOW } \\
\text { FLOWS } \\
\text { SAND HOLLOW } \\
\text { FLOWS } \\
\text { MARY HILL FLOW }\end{array}$ & $\begin{array}{c}\text { FLOW OF } \\
\text { KELLEY HOLLOW } \\
\text { FLOW OF } \\
\text { BADGER GAP } .\end{array}$ & 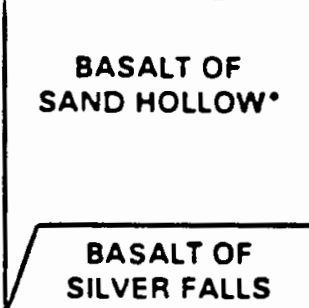 \\
\hline GINKGO FLOW & GINKGO FLOW & GINKGO FLOWS & BASALT OF GINKGO \\
\hline & $\begin{array}{l}\text { PALOUSE FALLS } \\
\text { FLOW }\end{array}$ & & $\begin{array}{l}\text { BASALT OF } \\
\text { PALOUSE FALLS }\end{array}$ \\
\hline
\end{tabular}

FIGURE 10. Correlation of Frenchman Springs terms by Deeson and others (1985), with previous authors 
differentiating between the basalt of Ginkgo and other Frenchman Springs flows, except for Sand Hollow, may present difficulty if relying on trace element chemistry alone. The $P O$ content in 25

Frenchman Springs basalt is very consistent within narrowly defined limits and was the primary determinant of the Ginkgo chemical type (>0.55\%; Table III). No other Frenchman Springs units contain $>0.55 \% \mathrm{P} 0$ which is defined as the lower limit for basalt of Ginkgo. 25

Additional characteristic physical evidence aids in the distinction of Ginkgo flow units. Ginkgo is the oldest Frenchman Springs unit in the Cascades, and lies immediately above the Vantage horizon, which may contain the Vantage interbed. This is not a definitive indicator in the Salmon River area for two reasons: (1) the Vantage horizon rarely contains interbedded material, and (2) the basalt of Ginkgo is not continuous with respect to the top of the Grande Ronde Basalt surface. The second physical property exhibited by basalt of Ginkgo flows is the distinctly higher concentration of large phenocrysts/glomerocrysts $(0.5-2.0 \mathrm{~cm})$ and the finer grained groundmass than stratigraphically adjacent flows. In most exposures this characteristic was sufficient to allow megascopic field identification. One to two flows of Ginkgo type basalt are exposed within the Salmon River area with a maximum thickness of $36 \mathrm{~m}$ in the Arrah Wanna exposure (Plate 1).

It is the most erratically distributed and discontinuous flow unit because it was the first Frenchman Springs basalt to 
encounter the previously formed structural relief on the Grande Ronde Basalt surface. Flows vary from approximately 25 m to zero meters in thickness as they onlapped and pinched out against existing paleo-highs. Evidence of this may exist in the Salmon River quarry exposure where the section exposed in south Boulder Creek appears to thin to the northeast towards the projected $\mathrm{N}$ $30^{\circ} \mathrm{W}$ structure.

Previous studies of CRB in the Cascades of Oregon show a strong correlation between the base of the basalt of Ginkgo and the presence of hyaloclastite deposits and pillow structures suggesting its incursion into paludal and lacustrine environments (Anderson,1978; Timm, 1979; Beeson and Moran, 1979b; Vogt, 1981). The absence of these features in the Salmon River area indicates that the areas where Ginkgo is currently exposed were relative highs in pre-Frenchman Springs time, or, more likely, elevated flat lying-surfaces. I believe it is reasonable to assume that paleo-lows existed within the Salmon River area and are not exposed because of continued downwarping and burial. Currently, these features are represented by large intervening areas where younger overlying volcanic materials are exposed.

Most exposures consist of one flow of this chemical type, but two flows were observed in a structurally abbreviated section along the southern edge of the Arrah Wanna exposure (N.E.1/4, N.W.1/4, sec. 7, T. 3 S., R. 7 E.; Plate 1) Ginkgo type flows are widely distributed throughout the Salmon River area in a discontinuous outcrop pattern. This unit pinches out in the 
upper Salmon River area toward the northwest from the mouth of Goat Creek. Ginkgo basalt is exposed along the Salmon River south of Rolling Riffle Campground (S.E.1/4, N.E.1/4, sec. 2, T. 4 S., R. 7 E.) and pinches out toward the mouth of Copper Creek to the southeast. A small segment of Ginkgo basalt is exposed along the southern side of the valley containing the South Fork Salmon River (S.W.1/4 and N.W.1/4, S.W.1/4, sec. 33, T. 4 S., R. 7 E. Here flows of Ginkgo overlie low-MgO Grande Ronde Basalt, but poor exposure and brecciation exposed in the stream bottom suggest structure may be responsible for this apparent stratigraphic anomaly.

Evidence attained from contact relations and flow distribution suggests that the structural evolution of the Grande Ronde Basalt paleo-surface strongly influenced the pathways of Ginkgo basalts as they flowed west through the Salmon River area. Areas where Ginkgo basalts are excluded from the Frenchman Springs section are interpreted as structural barriers to their advance. The developing northeast fold structures channeled the flows and are responsible for the discontinuous outcrop pattern along the northwest trend of the Salmon River.

The general absence of substantial interbedded material at the Vantage horizon may suggest that currently exposed basalts were relative topographic highs or well drained areas. The effect of erosion on the Ginkgo's lateral extent is unknown but should be aknowledged as a viable process locally. Erosion would be enhanced along structural margins where thinning occurred. 
Regional correlations in the CRBG with respect to the basalt of Ginkgo suggests a main channel penetrated the Cascades in the vicinity of the Salmon River area and was the primary pathway for the Ginkgo intracanyon flow (Beeson and others, 1985). The most probable location of this flow is south of Arrah Wanna and north of the upper Salmon River exposure where a projected synclinal low in the CRB surface is presently infilled with thick accumulations of the younger overlying Rhododendron Formation. Complete lack of exposure in this area inhibited observations that could verify or disprove the existence of an intracanyon flow of Ginkgo basalt. Complete chemical data for individual samples of Ginkgo basalt are listed in Appendices $E$ and $\mathrm{F}$.

Basalt of Silver Falls

The second distinctive Frenchman Springs unit to enter the area was the basalt of Silver Falls. The P 0 content (Table I) 25 coupled with trace elements $\mathrm{La}$ and $\mathrm{Cr}$ (Table II) is generally sufficient to distinguish the Silver Falls unit from other Frenchman Springs flows. The trace element concentrations of this unit closely resemble the Ginkgo chemical type and may be differentiated by its lower P O (<0.55\%; see Table I) and 25

slightly higher $\mathrm{Cr}$ content (21.60 ppm; see Table II). Physical properties that aid stratigraphic definition of the Silver Falls section include its coarse grained texture and sparse distribution of large $(0.5-1.5 \mathrm{~cm})$ phenocrysts. This contrasts 
well with Ginkgo type basalt but is rarely useful to distinguish it from the overlying Sand Hollow basalt.

The Silver Falls section consists of one flow approximately 25-50 m thick. This flow is restricted in occurrence to the upper Salmon River exposure where it encountered nearly the same structural controls as the preceeding Ginkgo type flows. This is determined by their contact relations which indicate similar outcrop patterns and lateral extent. Lateral thinning of this flow roughly mimics the underlying Ginkgo section achieving a slightly greater lateral extent as it onlapped the high-MgO structural boundaries. This flow unit is also laterally discontinious indicating that considerable relief was still present in the area after infilling by the Ginkgo flows.

Three flows of the basalt of Silver Falls chemical type occur in western Oregon at its type locality near Silver Falls Sate Park (Beeson personal communication, 1986). The presence of one Silver Falls flow in the Salmon River area suggests the other two flows, which also passed through the Cascades, were diverted. Stratigraphic position of the Salmon River area Silver Falls flow, with respect to the three-flow type section, is indeterminable. The absence of Silver Falls basalt north of Copper Creek in the upper Salmon River area indicates that its northward spread was terminated in that area. Complete chemical data for the basalt of Silver Falls samples is shown in Appendices $\mathrm{G}$ and $\mathrm{H}$. 
Basalt of Sand Hollow

The basalt of Sand Hollow is the most chemically distinct Frenchman Springs unit in the Salmon River area. This unit may be distinguished from other Frenchman Springs chemical types soley on the basis of $\mathrm{Cr}$ content (Table II). The average $\mathrm{Cr}$ composition of Sand Hollow basalt is $42.76 \mathrm{ppm}$, nearly two times that of other Frenchman Springs flows, but the composition of individual flows typically ranges between $30 \mathrm{ppm}$ and $50 \mathrm{ppm}$ (Appendix $\mathrm{J}$ ). Both the low and the intermediate $\mathrm{P} O$ chemical 25 type Sand Hollow flows are present, but major element analysis of this group of flows is insufficient to distinguish distributional variations. Other elements that support this chemical break include La and $\mathrm{Ce}$ (Table II). The abundance of phenocrysts in Sand Hollow flows is highly variable and ranges from abundant to rare. Hand sample identification of Sand Hollow flows is tedious and unreliable. When phenocrysts are not present, the Sand Hollow coarse-grained texture is typical of all. Frenchman Springs flows except for the Ginkgo type.

A maximum of four flows comprise the Sand Hollow section as exposed continuously along Kinzel Creek (sec. 7, T. 4 S., R. 8 E.). At this location, $134 \mathrm{~m}$ of basalt represent the thickest Sand Hollow and Frenchman Springs stratigraphic section exposed in the Salmon River area. The Sand Hollow chemical type, which common1y forms the top of the Frenchman Springs section, is ubiquitous to CRB exposures in the Salmon River area. This unit is also the most laterally continuous Frenchman Springs chemical 
type. Despite widespread distribution and lateral continuity, the number of flows varies between two and four and is absent locally in some areas, particularly near the mouth of south Boulder Creek. The persistent uniform thickness and laterally continuous nature of the upper two Sand Hollow flows is evidence that structural relief was almost completely infilled during Sand Hollow time. The upper two flows covered the Salmon River area with an average thickness of $60 \mathrm{~m}$. This is an important observation for the interpretation of the structural development of the area.

The predominant Frenchman Springs section in the northern part of the study area consists of three flows of Sand Hollow basalt with uniform thickness overlain by a single flow of the last CRB to enter the area. This relationship is well documented in the northeastern Brightwood exposure (sec. 19, sec. 29, sec. 30, T. 2 S., R. 7 E. and N.E.1/4, sec. 24, T. 2 S., R. 6 E.) where Frenchman Springs basalts are exposed laterally for a distance of $3.6 \mathrm{~km}$, and in the Alder Creek exposure. The typical Frenchman Springs section is disrupted in the Salmon River quarry exposure. At this locale, the Sand Hollow flows exposed in south Boulder Creek pinch out to the northwest and thin to the northeast where they overlie high-Mg0 Grande Ronde Basalt in the absence of Ginkgo basalt. Immediately west of north Boulder Creek the entire Frenchman Springs section is absent. East of this ridge, the typical Frenchman Springs section is exposed as mentioned above. Three separate Frenchman Springs sections 
within the Arrah Wanna exposure are atypical and result from the absence of either Sand Hollow basalt or Sentinel Gap basalt. Despite these irregularities, a predominent five flow (1-Ginkgo basalt, 3-Sand Hollow basalt, and 1-Sentinel Gap basalt) Frenchman Section persists in the northern part of the Salmon River area. Complete chemical data for the Sand Hollow basalt samples are shown in Appendices $I$ and $J$.

Basalt of Sentinel Gap

Sentinel Gap basalt flows are an intermediate $\mathrm{Cr}$ chemical type with an average concentration of $21.60 \mathrm{ppm}$ (Table II) and are thus easily distinguished from underlying Sand Hollow types. The $\mathrm{P} O$ content of this flow unit overlaps with Silver Falls and 25

Sand Hollow chemical types. The relatively intermediate $\mathrm{Cr}$ content of Sentinel Gap basalt is also nondistinctive and overlaps the $\mathrm{Cr}$ content for Sand Hollow and Silver Falls basalt when the range of analytical error is considered. Major-oxide data show a lower MgO content (3.93\%) in Sentinel Gap basalt (Table I) and helps separate it from other Frenchman Springs basalts.

This flow unit is the least chemically distinct within the Frenchman Springs section. All available data, including the megascopic evidence discussed below must be considered collectively to distinguish this unit. Stratigraphic position of the Sentinel Gap flow at the top of the CRB section is the most important distinguishing physical characteristic. The relative 
absence of phenocrysts in this flow is useful to distinguish it from underlying phenocryst bearing Sand Hollow flows. The bluish translucent color of the Sentinel Gap basalt, as seen on fresh surfaces, is characteristic and can be used in megascopic identification.

The Sentinal Gap section represents the last flow of CRB to pass through the Salmon River area. The Sentinel Gap section is composed of a single cooling unit 24-30 $\mathrm{m}$ thick and is well exposed north of Brightwood below the powerline (S.E.1/4, N.E.1/4, and S.W.1/4, N.E.1/4, sec. 29, T. 2 S., R. 7 E.). This flow is also present in the top of the section exposed in the Salmon River quarry area along south Boulder Creek (N.W.1/4, S.W.1/4, sec. 36, T. 2 S., R. 6 E.) and in the Alder Creek exposure.

Approximately $30 \mathrm{~km}$ north and west of the Salmon River area (N.1/2, sec. 28, T. 1 S., R. 4 E.) near Cottre11, Oregon, chemical data from the Hood Acres drill hole show distinct breaks in the Sentinel Gap section (Beeson, personal communication, 1986). The variability of $\mathrm{TiO}$ and $\mathrm{P} O$ allows division of this $2 \quad 25$ section into three distinct chemical flow units (Table IV). These units are distinguished by their relative compositions into (oldest to youngest): (1) 1ow-TiO/high-P 0 P 020250 25 , and (3) high-TiO /low-P 0 . Comparing these data with the average Sentinel Gap concentrations from the Salmon River area, a close match is evident with the high-TiO/low-P 0 chemical type. The $\mathrm{P}_{2} \mathrm{O}_{5}$ and TiO contents for Sentinel Gap samples from the 


\section{TABLE IV}

Comparison of the Salmon River area Sentinel Gap

Composition with the Hood Acres Well

\begin{tabular}{|lrrrr|}
\hline & & & & \\
& & & & \\
& & & & \\
& $1(1)$ & $2(1)$ & $3(1)$ & $4(8)$ \\
$\mathrm{SiO}$ & 52.59 & 52.48 & 52.49 & 52.39 \\
$\mathrm{~A} 1203$ & 15.17 & 14.48 & 14.23 & 14.26 \\
$\mathrm{TiO}$ & 3.01 & 3.18 & 3.13 & 3.12 \\
$\mathrm{FeO}$ & 12.15 & 12.24 & 12.30 & 12.00 \\
$\mathrm{MnO}$ & 0.22 & 0.23 & 0.20 & 0.23 \\
$\mathrm{CaO}$ & 7.75 & 7.82 & 7.75 & 8.01 \\
$\mathrm{MgO}$ & 4.01 & 3.80 & 4.09 & 4.15 \\
$\mathrm{~K} 20$ & 1.20 & 1.05 & 1.19 & 1.08 \\
$\mathrm{Na} 20$ & 2.26 & 2.14 & 2.11 & 2.25 \\
$\mathrm{P} 205$ & 0.56 & 0.57 & 0.52 & 0.52 \\
& & & & \\
\hline
\end{tabular}

$(n)=$ number of samples averaged

(1) Hood Acres well, low-Ti02/high-P205 Sentinel Gap basalt, bottom unit (Beeson, personal communication, 1986)

(2) Hood Acres well, high-Ti02/high-P205 Sentinel Gap basalt, middle unit (Beeson, personal communication, 1986)

(3) Hood Acres well, high-Ti02/low-P205 Sentinel Gap basalt, top unit (Beeson, personal communication, 1986)

(4) Salmon River area, high-Ti02/low-P205 Sentinel Gap basalt, single flow, top of CRB section (this study) 
Salmon River area suggest this to be a reliable method of distinguishing between various flows units. Data published by Beeson and others (1985) also show that the TiO and P 0 oxides of the Sentinel Gap basalt have a narrow and uniform compositional range. Thus, if correlation is possible based on these oxide concentrations, the high-TiO / low-P O Sentinel Gap flow in the Salmon River area corresponds to the youngest of three compositionally varied Sentinel Gap basalt units that entered the Hood Acres area. This occurrence suggests that previous Sentinel Gap flows approached the Cascades and were blocked from entering the Salmon River area. Infilling eventually overcame the obstacles, and allowed the last flow to flood over areas where Sentinel Gap basalt was previously exc1uded.

Because Sentinel Gap basalt occupies the top of the stratigraphic section, it is a likely candidate for removal by erosion. For this reason, caution must be used when relating the contact relationships and distribution of the Sentinel Gap chemical type to paleo-topography. Complete chemical data for Sentinel Gap basalt samples are shown on Appendices $\mathrm{K}$ and $\mathrm{L}$. 
Summary of Stratigraphy

Careful observation of the CRBG stratigraphy is critical to the success of this study. Lacking continuous exposure, lateral stratigraphic relationships become difficult to correlate across areas of poor exposure. Therefore, trends, patterns, and successions must be observed in detail to successfully utilize local stratigraphic variations for structural analysis. The observations below are the result of field mapping and detailed stratigraphic analysis of 166 samples for trace and (or) major elements.

The Grande Ronde Basalt is present everywhere the CRBG section is exposed to a sufficient depth. Its thickness and lateral extent suggest that the Grande Ronde Basalt covered the entire paleo-surface of the Salmon River area. Variations in the thickness, and in the number of high-MgO flows are attributed to erosion of the upper surface during Vantage time and to gradual structural deformation prior to and during its incursion. Subsequent Frenchman Springs Basalt flows show irregular, discontinuous pattens of distribution throughout the Salmon River area. The first Frenchman Springs basalt, Ginkgo chemical type, is one of the most laterally discontinuous units, but it is distributed throughout the entire Salmon River area.

The overlying Silver Falls basalt flow shows the same laterally intermittent distribution as the Ginkgo flows, but they are restricted in their distribution to the upper Salmon River 
exposure. Northeast-trending structures are believed to be responsible for this occurrence. At least two other flows of Silver Falls basalt that passed through the Cascades are either unexposed or were diverted from the Salmon River area, probably to the south. Explanations for this include: (1) development of structures that initially channeled flows, (2) containment of these flows by the projected syncline where the Ginkgo intracanyon flow is believed to exist.

Flows of Sand Hollow basalt were the next unit to flow through the area. They form the most widespread and voluminous Frenchman Springs unit and covered the area with a sequence of up to four flows. The number of flows and the stratigraphic thickness vary throughout the Salmon River area reflecting the paleo-relief encountered by initial Sand Hollow flows. This was eventually infilled allowing the top of the Sand Hollow section to spread uniformly over the area.

Sentinel Gap basalt was The last Frenchman Springs flow to enter the area before Cascadian volcanism blocked the path of subsequent CRB flows. This represents the top of the CRB section in the Salmon River area with uniform distribution and thickness. It was restricted, however, by structure or by younger volcanic buildup from entering the southern part of the study area. In its absence, Sand Hollow basalt forms the top of the section within the upper Salmon River exposure. 
CHAPTER III

\section{SALMON RIVER AREA BASALT STRUCTURE}

The Cascade Range of Oregon has been the subject of several large-scale tectonic and petrologic studies (Wells and others, 1961 ; Peck and others, 1964; Wise, 1969). More recently, primarily because of geothermal interests, numerous detailed studies using techniques such as gravity, magnetics, magnetotellurics, and SLAR imagery along with geochemistry have been employed to help refine the structure of the northern Cascades of Oregon (Anderson, 1978; Beeson and Moran, 1979b; Hammond, 1979; Bond and others, 1980; Beeson, 1982; Flannagan and Williams, 1982; Kohler and others, 1982; Williams and others, 1982). A re-occurring pattern of $\mathrm{N} 30^{\circ} \mathrm{W}$ and $\mathrm{N} 50^{\circ}-80^{\circ} \mathrm{E}$ structures is evident within the Salmon River area and surrounding Northern Cascade Range. This regional type structural pattern is, therefore, believed to have strongly influenced the tectonic evolution of the CRB in the Salmon River area, which displays a distinct, northwest outcrop pattern over a distance of nearly $48 \mathrm{~km}$. The most prominent structures that conform to the regional trend consistently throughout the area are thrust faults, faults with normal and high-angle reverse senses of movement, en-echelon series of fold axes, and prominent 
joints and joint sets. The most visible evidence of the degree of structural deformation in this area includes the interupted noncontinuous basalt exposures, extensive areas of tectonic breccia, and steep1y dipping beds (up to $40^{\circ}$, but more commonly $\left.15^{\circ}-25^{\circ}\right)$. These structures are pervasive throughout exposed CRB in the Salmon River area controlling its outcrop pattern and influencing stream directions.

\section{$\underline{\text { Folds }}$}

The occurrence of a broad synclinal and adjacent anticlinal axes in the Salmon River area was suggested by reconnaissance work (Beeson and others, 1982). This was based on the presence of large-scale regional folding in the Columbia Plateau (Watkins and Baski, 1974; Bently, 1977) and its projection into the Cascade Range noted by previous studies in the Hood River area and in the Bull Run River drainage (Timm, 1979; Vogt, 1981) and its coincidence with the Salmon River area (see Figure 11). This study suggests that the small-scale fold system in the Salmon River area consists of several small scale folds imprinted on broad regional type structures. The fold axes in the Salmon River area form a crude en-echelon pattern oriented $\mathrm{N} 50^{\circ}-80^{\circ} \mathrm{E}$ conforming to the regional trends that have become frequently disrupted by northeast-trending associated fault structures. Because of the thickness of the overlying younger volcanics (several thousand meters at Hunchback Mountain; Priest, 1982a), 


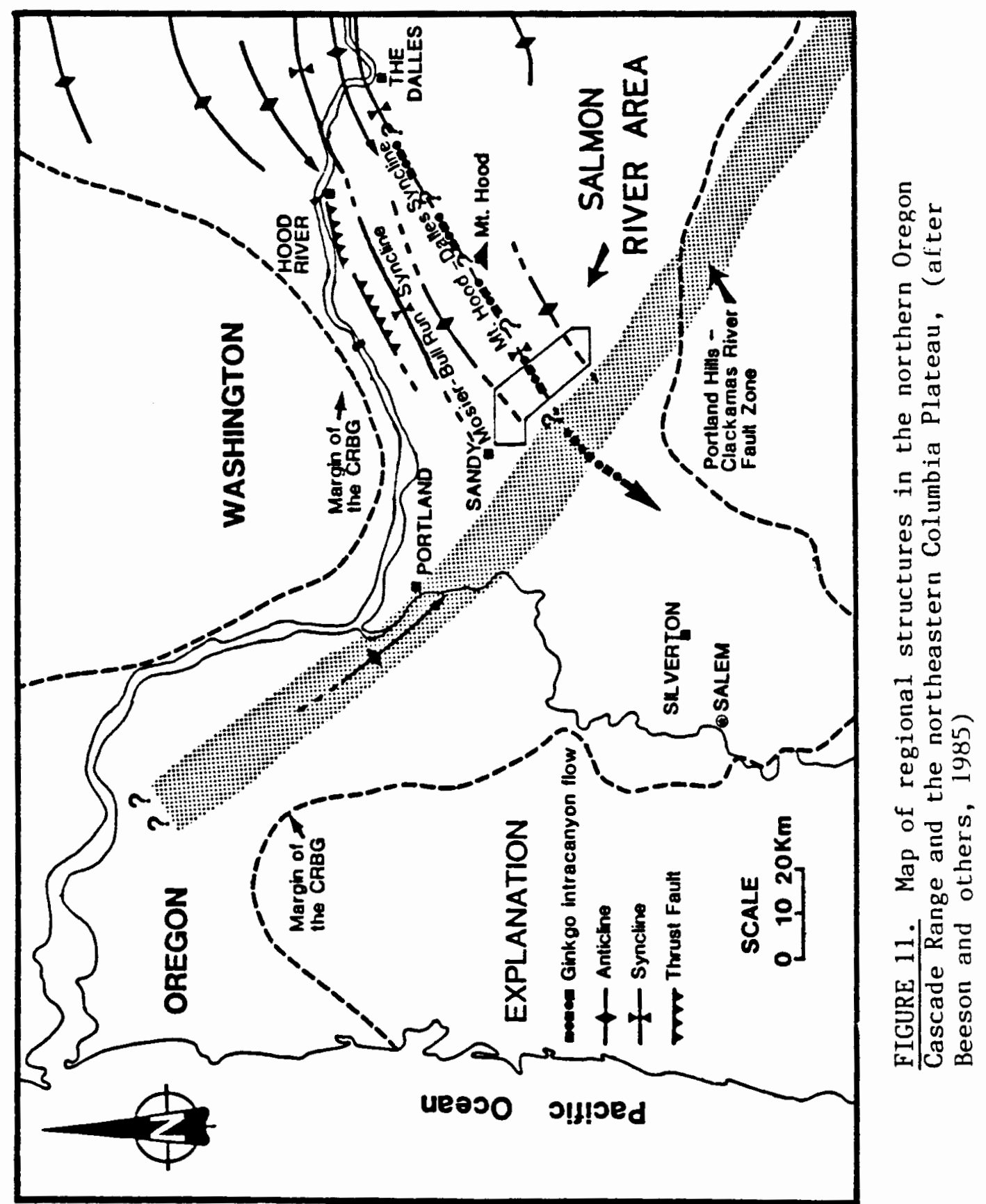


the basalts that form large-scale synclinal features and broad structural lows are currently not exposed.

The upper Salmon River exposure, previously mapped as a single broad anticline (Beeson and Moran, 1979b), contains one well defined syncline and two adjacent anticlines. The $N 55^{\circ} \mathrm{E}-$ trending synclinal axis crosses the present-day Salmon River between Goat Creek and Kinzel Creek (Figure 12). The fold is most evident along the Salmon River as determined by contact relations. The CRB flows along the Salmon River become increasingly older upstream and downstream from the axis of the fold as seen near the mouth of Goat Creek (N.E.1/4, N.E.1/4, sec. 12, T. 4 S., R. 7 E.) and Tumbling Creek (S.E.1/4, S.W.1/4, sec. 7, T. 4 S., R. 8 E.; see Plate 1). Between these two locations the maximum measured thickness of Sand Hollow basalt exists, and the base of the unit is not exposed near the center of the axis. The Salmon River is oriented roughly perpendicular to the northeast-trending fold axes and exposes the fold profile along its length. The elevated nature of the basalt surface adjacent to the synclinal axis suggests that anticlinal structures are present south of the mouth of Tumbling Creek and near the mouth of Copper Creek trending $\mathrm{N} 65^{\circ} \mathrm{E}$ and $\mathrm{N} 46^{\circ} \mathrm{E}$, respectively (see Plate 2, map pocket). These structures are not as well defined because of the degree of subsequent faulting and brecciation along their northern limbs. They are defined primarily by the statigraphic relationships of the Frenchman Springs basalt as they pinch out against the elevated Grande Ronde Basalt section 


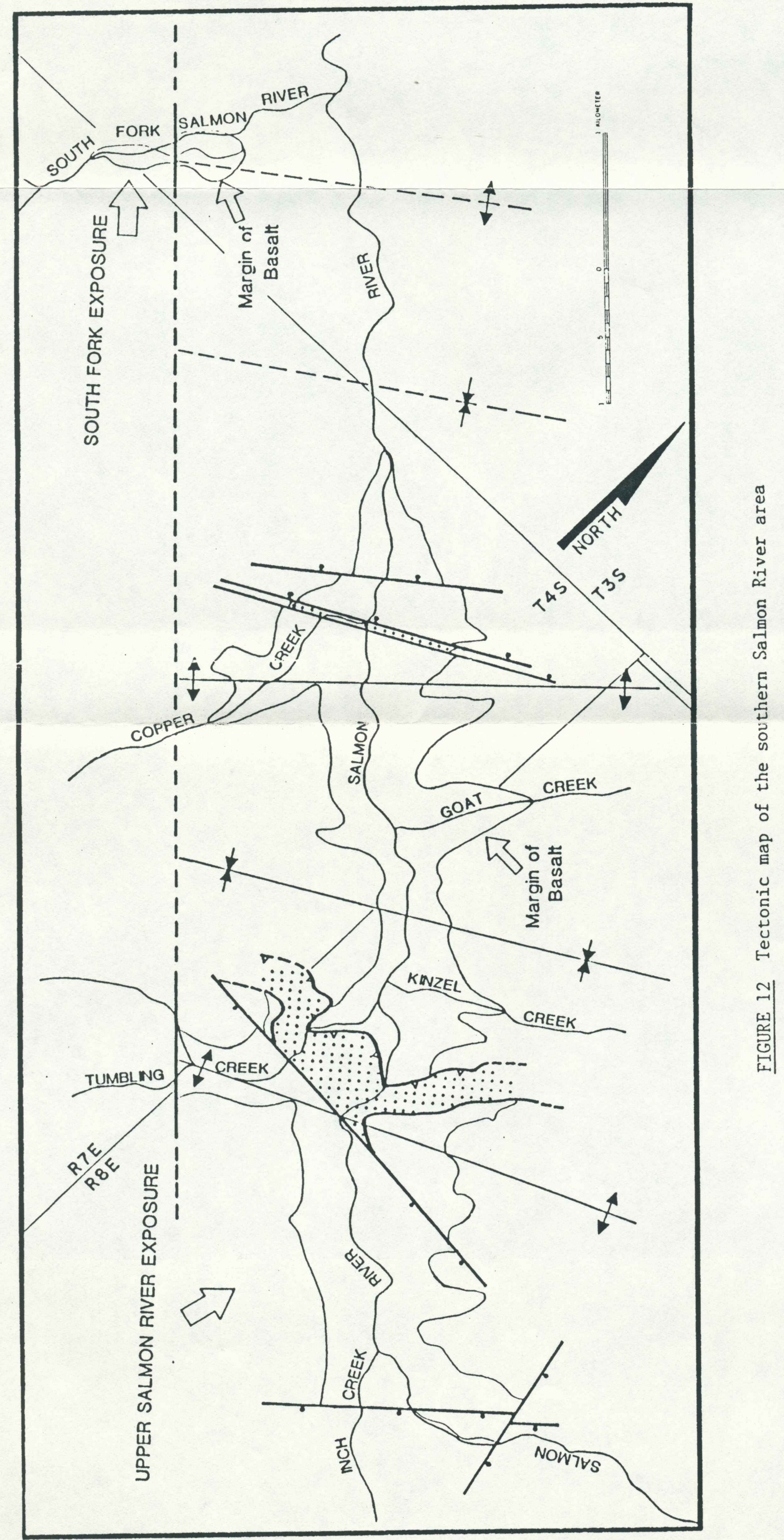


(Plate 2). The lower Frenchmen Springs flows, Ginkgo and Silver Falls, pinch out to the north towards each axis and are excluded from the crest. The northern limb of the Copper Creek anticline dips approximately $20^{\circ}-25^{\circ}$ where it disappears beneath Rhododendron cover at the northern extent of the upper Salmon River exposure (N.E.1/4, sec. 2, T. 4 S., R. 7 E.). When compared with the gradual $10^{\circ}$ to $15^{\circ}$ dip of the southern limb an asymmetrical fold style is suggested. The axis of the Copper Creek anticline crosses the Salmon River near the only outcrop of Prineville chemical type basalt representing the lowest stratigrphic horizon exposed in the Salmon River area. The top of the CRB is clearly elevated (as much as $122 \mathrm{~m}$ near Tumbling Creek; Plate 2) in the areas corresponding to anticlinal axes. However, the additional uplift from associated structures makes it difficult to determine the actual amount of uplift caused by folding .

Folding is also shown in the Brightwood and Salmon River quarry exposure to the north where prominent anticlines were mapped (Figure 13). Because of differences in fold style and Frenchman Springs stratigraphy, these structures do not correlate across the present day intervening valley and represent different generations of folding. The Frenchman Springs section in the Salmon River quarry exposure thins over the crest of the anticline which formed prior to the anticline in the Brightwood area that lacks this stratigraphic thinning. 





In the Salmon River quarry area the fold is structurally complicated, but the orientation of the flows along the trend suggests the overall influence of deformation caused by folding. A synclinal axis is interpreted to exist southeast of the anticline with a similiar orientation and is responsible for the disappearance of the basalt beneath the Rhododendron Formation. The syncline is centered between the Arrah Wanna exposure and the Salmon River quarry exposure where it is represented by a covered interval. Northwest-dipping Frenchman Springs flows in the Arrah Wanna area form the southeastern limb of the syncline before the basalt disappears beneath Rhododendron material; reappearing to the northwest as the steeply inclined limb of the prominent anticline (P1ate 2).

Folds that may have formed in basalts at the Arrah Wanna exposure are severely complicated and not well exposed, however, folding was detected from contact relations. Dips measured in overlying medium-grained Rhododendron sandstones support the folded nature of the Arrah Wanna exposure (Plate 1).

The lack of CRB to the northwest and southeast of the Arrah Wanna and Salmon River quarry areas broad tectonic depressions. The limited exposure of $\mathrm{CRB}$ in the Alder Creek exposure and south fork exposure may represent minor anticlinal features within these broad tectonic depressions. Tectonic breccia in the basalts exposed along the South Fork of the Salmon River suggests structural uplift of undetermined nature. 


\section{$\underline{\text { Faults }}$}

The Salmon River area contains a series of faults and fault-related structures that is a predominant part of the overall structural fabric and conforms to the regional tectonic pattern. Accurate stratigraphic correlation is an essential tool for distinguishing between offsets of the section caused by faulting or by lateral thinning. Further field criteria that aids in fault determination include the presence of oriented breccia zones, breccia stringers, and topographic features such as changes in stream direction, outcrop pattern, contact relations, waterfalls, and occasional lineaments viewed on aerial photographs. The occurrence of waterfalls is sometimes caused by the upstream dip of the basalt flows and is often not related to faulting.

Most of the structures mapped in the Salmon River area were based on multiple lines of evidence with emphasis on the stratigraphy in areas of poor lateral exposure. Three distinctive types of northeast-trending faults were recognized within the Salmon River area. Two of these, which are related to the north-south compressional fold system, are high-angle reverse faults and low-angle thrust faults. The third and contrasting fault style consists of northeast-trending normal faults. 
Northeast-Trending Faults

The effects of thrust faulting in CRB has been described in the Bull Run River area to the north (Vogt, 1981) where a thrust was defined by a low-angle fault plane underlying several hundred feet of highly brecciated basalt in the overriding plate. Two locations in the Salmon River area (near the mouth of Tumbling Creek and along the northwestern portion of the Arrah Wanna exposure; W.1/2, sec. 6, T. 3 S., R. 7 E.) contain large areas of tectonically brecciated basalt coincident with considerable stratigraphic displacement (Plate 2). At both locations the southeastern block has been thrust at a relatively low angle over the northwest block intensely brecciating the lower portion of the overriding plate. The sense of movement by the overriding plate is to the northwest in both areas.

A highly brecciated zone of basalt with an estimated thickness of $80 \mathrm{~m}$ crops out in the Tumbling Creek thrust zone (Plate 2). Waterfalls occur where the thrust zone crosses the Salmon River and Tumbling Creek. Stratigraphic displacement is well defined along the Salmon River where northwest-dipping Frenchman Springs basalt flows are stratigraphically below the breccia zone and low-MgO flows of Grande Ronde Basalt. The breccia within the thrust zone was not suitable for chemical analysis because of weathering but was megascopically similar to low-MgO basalt. The actual thrust plane was not discovered, but its northeast trend is suggested from the outcrop pattern of the breccia zone and its tendency to "V" upstream where it crosses 
the Salmon River and Tumbling Creek. The extensive nature of the breccia zone makes it difficult to determine whether a single, well-defined slip plane exists or if movement occurred along an indistinguishable series of parallel curviplanar surfaces. Previously brecciated basalt may have existed in response to folding under conditions similar to those described by Beeson and Moran (1979b) along the axial plane of folds in CRB. Approximately $122 \mathrm{~m}$ of stratigraphic displacement is attributed to movement along this fault. This offset was determined by the difference in the top of the Sand Hollow section across its trend.

The thrusted nature of $\mathrm{CRB}$ in the Arrah Wanna exposure is clearly defined along its northwestern edge where brecciated Low$\mathrm{MgO}$ Grande Ronde Basalt overlies Frenchmen Springs basalt. This study revealed that two northeast-dipping, thrust sheets are exposed in the Arrah Wanna area (Plate 2).

Individual fault planes were not identified in the Arrah Wanna thrusts but the northeast orientation of the thrusted zone is determined by the orientation of the two thrusted sheets and by the outcrop pattern of the brecciated Grande Ronde Basalt. These relationships suggest a northwest sense of movement by the overriding block. The tectonic forces that could produce this feature are consistent with the previously described northeasttrending fold structures. The massive nature of the tectonic breccia zone complicates attempts to accurately determine the orientation of the fault plane. Subsequent faulting has affected 
the outcrop pattern of the equant shaped, 152-183 m thick zone of brecciated basalt as it is exposed today.

Typically, thrust faults are characterized by the outcrop pattern of the fault plane, which roughly simulates topographic lines because of its low angle. The northwest edge of the Arrah Wanna thrusts crop out along a northeast trend roughly following the draw near the northwest edge of the exposure from the valley floor (1,200 ft elevation) to an elevation of 2,920 ft. This is not the trend a low angle plane would be expected to display attesting to the effects of subsequent deformation in the area.

High-angle reverse faulting is evident in the Brightwood exposure east of north Boulder Creek (W.1/2, N.E.1/4, sec. 24, T. 2 S., R. 6 E.) and north of the mouth of Copper Creek along the Salmon River (W.1/2, sec. 1, T. 4 S., R. 7 E.; Plate 1). These northeast-trending faults crop out in a straight line, which indicates a high angle of dip, and are consistent with a northwest to southeast compressive stress field.

The path of Copper Creek, near its mouth, appears to be deflected by this structure into a prominent northeast trend, and Prineville chemical type is exposed immediately to the south of the projected fault plane on the uplifted block. Approximately $0.3 \mathrm{~km}$ north of the mouth of Copper Creek, another high-angle reverse fault, trending $\mathrm{N} 52^{\circ} \mathrm{E}$, crosses the Salmon River (Plate 2). Tectonic breccia accompanies these faults but is not a dominant feature. Rather, it occurs as irregular, discontinuous stringers with preferred orientation and as poorly exposed zones 
but does not form laterally extensive continuous features.

The high-angle reverse fault near Brightwood, is identified by the elevated nature of Grande Ronde Basalt flows that are exposed on the ridge containing the new Brightwood quarry (S.W.1/4, N.E.1/4, sec. 24, T. 2 S., R. 6 E.). These flows dip $33^{\circ}$ to the northwest and are terminated to the east by the fault (Plate 3). Poor exposure which results from heavy vegetation on the southeast side of the ridge, conceals the fault plane and brecciation that may be associated with it. The steeply-dipping beds flatten to the northwest from the ridge, dip $20^{\circ}$ in north Boulder Creek, and approach horizontal beyond (see Plate 2). A prominent, highly brecciated zone of low-Mg0 basalt is located in the bed of north Boulder Creek for a distance of $0.5 \mathrm{~km}$ above its confluence with the Salmon River. This zone was not observed beyond the bed of the creek and its trend was not discernable. Because of the apparent lack of offset across this feature, its relationship to the surrounding structure is not obvious. The position of the breccia zone coincides with the area of maximum flexure between the steeply dipping beds to the southeast, and the flatter-lying beds to the northwest and were probably formed by the folding in the area.

Grande Ronde Basalt is exposed along the ridge containing the Brightwood quarry, from the Salmon River (1200 ft elevation) to an elevation of $2,000 \mathrm{ft}$ where the top of the high-MgO is overlain by Rhododendron material. Frenchman Springs basalt is exposed east of the fault plane from an elevation of $1,600 \mathrm{ft}$ to 
the valley floor $(1,200 \mathrm{ft}$ elevation). This indicates a maximum upward throw of 122-152 $\mathrm{m}$ by the northwestern block. The uplifted nature of the Grande Ronde Basalt on the ridge is probably enhanced by folding, but the amount was not determined. The apparent exclusion of Frenchman Springs basalt immediately northwest of the fault plane suggests that uplift began prior to its incursion. The earliest Frenchman Springs flows may have existed across the structure and later eroded as a result of the uplift. The presence of Sentinel Gap basalt in the first draw to the northwest of north Boulder Creek (N.E.1/4, N.W.1/4, sec. 24, T. 2 S., R. 6 E.) creates a degree of uncertainty regarding the extent of Frenchman Springs basalt over the structure in this area.

The $\mathrm{N} 62^{\circ}$ E-trending fault located at the southern edge of the upper Salmon River exposure appears to have a normal sense of vertical displacement (S.1/2, sec. 17, T. 4 S., R. 8 E.). This structure terminates the CRB outcrop by downward normal displacement of the southeastern block. Juxtaposition of Frenchman Springs basalt with Rhododendron material to the east and a prominent bend in the Salmon River support this interpretation. The gentle southeasterly dip of the basalt in this area is not sufficient to cause such a rapid disappearance, especially considering the low gradient of the Salmon River and Inch Creek. Another normal fault also crosses the Salmon River with a $\mathrm{N} 80^{\circ} \mathrm{E}$ trend south of the mouth of Tumbling Creek. Slight downward displacement to the southeast in the Frenchmen 
Springs basalt section was determined by contact relations on the east side of the Salmon River and its effect on the outcrop pattern of tectonic breccias associated with the Tumbling Creek thrust. This structure also forms a distinct aerial photo linear that tends to confirm its presence.

Northwest-Trending Faults

The most strikingly obvious northwest trend is the overall outcrop pattern of the CRB in the Salmon River area (Plate 1). The actual structures that define this trend are not easily discerned, and must be projected across expansive, intervening areas of younger volcanic material. However, the continuous nature of the structural trend is consistently supported where exposure is suitable.

Several observations indicate the presence of northwesttrending faults in the Salmon River quarry exposure (Plate 1). Observations include thinning and pinching out of flows within the Frenchman Springs section where they cross the projected trend of the structure. A northwest-trending sharply defined fault plane was noted in a draw along the south side of the Salmon River adjacent to the Salmon River quarry. One meter of upward displacement to the northeast was indicated at the high$\mathrm{MgO} / 1 \mathrm{ow}-\mathrm{MgO}$ basalt contact. This may indicate that the primary fault zone associated with this structure is located nearby to the west. Ginkgo basalt flows pinch out across the structure and are not present immediately to the east where a well exposed 
section dips beneath Rhododendron material. The entire Sand Hollow section thins to the east from south Boulder Creek and immediately overlies high-MgO Grande Ronde Basalt in the absence of Ginkgo. These features are attributed to the strong influence of the $\mathrm{N} 30^{\circ} \mathrm{W}$ structure by upward displacement of the northeast block.

Previous work has suggested that right-lateral movement was the predominent sense of motion associated with the $\mathrm{N} 30^{\circ} \mathrm{W}$ structural zone (Beeson and Moran, 1979b). A well-exposed N $30^{\circ}$ W, $90^{\circ}$ fault plane in the new Brightwood quarry was determined to have a right-lateral last sense of movement from slickensides that plunge $30^{\circ}$ to the northwest. The displacement along this fault probably occurred prior to the subsequent uplift, which tilted the entire basalt section $33^{\circ}$ to the northwest. The plunge of the slickensides, therefore, reflects the uplift of the basalt section in the area and does not suggest 30 degree oblique movement along the fault plane. Approximately $9 \mathrm{~m}$ of upward displacement by the northeastern block occurred prior to the right-lateral last sense of motion.

Continuation of the $\mathrm{N} 30^{\circ} \mathrm{W}$ structural zone into the Arrah Wanna exposure is indicated by faulting of the Frenchmen Springs section along the northwest edge of the exposure and northwestoriented breccia zones (Figure 13). Much of the upper Salmon River exposure is believed to lie east of the $\mathrm{N} 30^{\circ} \mathrm{W}$ structural zone in that area. 
The $\mathrm{N} 42^{\circ} \mathrm{W}$-trending fault, located near the first fork in Tumbling Creek upstream from its mouth (E.1/4, sec. 13, T. 4 S., R. 7 E.) is a southern continuation of the $\mathrm{N} 30^{\circ} \mathrm{W}$ structural zone into the upper Salmon River exposure. The actual plane of the fault was not detected, but it was stratigraphically identified by the juxtaposition of Rhododendron material with high-MgO Grande Ronde Basalt in the creek bed where the fault crosses. The elevated nature of the northeast block is consistent with offset observed along this trend in the Salmon River quarry, and in the Arrah Wanna exposure. The $\mathrm{N} 42^{\circ} \mathrm{W}$ fault near Tumbling Creek forms a crude lineation with the south fork exposure. Northwest-oriented breccias along the South Fork Salmon River could represent structural deformation that resulted from north and south continuation of the $N 30^{\circ} \mathrm{W}$ structural zone into that area.

This large scale feature may be summarized as a $\mathrm{N} 30^{\circ} \mathrm{W}-$ trending structural zone with upward displacement of the northeast block and with late, right-lateral motion. The feature is poorly exposed, but is probably responsible, in part, for the $\mathrm{N} 30^{\circ} \mathrm{W}$ CRB outcrop pattern, the trend of the Salmon River, and the lack of basalt outcrop west of this zone.

If the $\mathrm{N} 30^{\circ} \mathrm{W}$ structural zone was not the terminous of the northeast-trending fold system seen in the Salmon River area, CRB should be exposed to the west online with the trend of presentday, northeast-trending structures. CRB to the west of the zone lacks the uplifted structural fabric associated with basalt 
outcrops in the Salmon River area observed east of the $\mathrm{N} 30^{\circ} \mathrm{W}$ structure.

\section{Joints}

Tectonically jointed CRB is pervasive throughout the entire Salmon River area. Typically, a single joint direction will appear to dominate in a given area, as determined by its abundance and well defined nature. Frequently, a less dominant, complementary joint direction is also present. Joint directions are generally oriented to the northwest and northeast with a consistent near vertical dip. The upper Salmon River exposure contains the largest continuous outcrop of CRB coupled with the optimum conditions for observing joints on the clean swept surfaces below the high water line of the Salmon River. Orientations of the prominent joints and joint sets were taken along the length of this exposure. An overall shift in the trend of the northeast- and southwest-oriented joint sets is evident. The prominent northwest joint direction varies consistently from $\mathrm{N} 77^{\circ} \mathrm{W}$ in the southern part of the exposure to $\mathrm{N} 44^{\circ} \mathrm{W}$ in the north near Rolling Riffle Campground (N.E.1/4, sec. 2, T. 4 S., R. 7 E.). The prominent northeast-trending joint set shows a similiar, less defined trend from $\mathrm{N} 52^{\circ} \mathrm{E}$ in the south to $\mathrm{N} 44^{\circ} \mathrm{E}$ in the north. Insufficient data were collected to speculate on the tectonic history of the area with respect to the formation of this trend. 


\section{Summary of Structure}

The structures described by this study represent two stages of development. The gentle northeast-trending folds in the Salmon River area marked the beginning of deformation of the CRB. These structures had a pronounced effect on the distribution and thickness of the lower Frenchman Springs section. Subsequent flows of the Frenchmen Springs basalt rapidly infilled the paleorelief and restored the original flat-lying nature of the Salmon River area. The apparent lapse of structural development during Frenchman Springs time resulted from the volume and rapid succession of flows into the area. Eventually, the upper Sand Hollow flows completely infilled the topography, overflowed, and masked the gradually developing structures. Essentially the same tectonic forces associated with the previous gentle folding resulted in a second observable episode of deformation beginning after the last CRB flows had entered the area. Deformation from this period formed broad folds and continued folding of previously initiated axes. These structures are reflected by the upper surface of the Sand Hollow basalt, which suggests that northeast-trending, high-angle reverse faults and thrusts are also related to this deformational episode.

Peck and others (1964) and Beeson and Moran (1979b) suggested that the projected $\mathrm{N} 30^{\circ} \mathrm{W}$ structural zone forms a boundary between two structural types and marked the southwestern 
termination of the Columbia Plateau style folding with the northeastern edge of the Portland Hills type structure. The conclusions resulting from this study tend to support that theory.

Stratigraphic relationships and the association with folding suggest that the $\mathrm{N} 30^{\circ} \mathrm{W}$ structural zone remained active throughout the CRB history. The sense of movement along this zone alternates between normal and right-lateral displacement. Right-lateral displacement is more difficult to determine with the methods employed by this study. Vertical displacement was, therefore, observed to be the dominant sense of movement along the $\mathrm{N} 30^{\circ} \mathrm{W}$ structural zone in the Salmon River area.

Northeast-trending normal faults represent the youngest recorded structures in the $\mathrm{CRB}$ history in the Salmon River area. They formed during a lapse in the predominent northwest-southeast compressive regional stress field. 
CHAPTER IV

\section{GEOLOGIC HISTORY}

In the Clackamas River drainage, the nature of the basal contact implies CRB incursion onto a flat-lying surface with relative highlands producing forests, and adjacent depressed areas with ponded water (Anderson, 1978). In the Salmon River area, the base of the CRB section is not exposed; therefore, information regarding the nature of its environment of invasion is limited. Low-MgO Grande Ronde Basalt is the lowest stratigraphic horizon exposed except for a limited segment of Prineville chemical type and the top of the N2/R2 paleo-magnetic boundary .

The thickness of Grande Ronde Basalt sections in surrounding areas (Clackamas River and 01d Maid Flat), suggests an additional 300-400 m of Grande Ronde Basalt could exist beneath the Prineville horizon in the Salmon River area (Anderson, 1978; Vogt, 1981; Priest, 1982b). The lowest observable flow units appear to have uniform lateral thickness and continuous lateral distribution.

Gradual structural development resulted in the irregular surface encountered by Frenchman Springs flows in the Salmon River area. Within a period of approximately $2.7 \mathrm{m.y} ., 750-1,000$ 
$\mathrm{m}$ of basalt entered the area. Each subsequent flow recorded the structural and erosional development of the paleo-surface formed during the preceding interflow interval. A period of rapid infilling during most of Frenchman Springs time ended after the last CRB flows entered the area. Following this episode, some of the more pronounced deformational features seen today were formed.

The Grande Ronde Basalt section in the Salmon River area lacks exposed interbeds and pillow structures. Thick (10-35 m), laterally extensive interbeds within Grande Ronde Basalt horizons in the Clackamas River drainage to the south are a common occurrence and are attributed to periodic activity of nearby volcanic centers (Anderson, 1978).

The lack of interbeds in exposed segments of the Grande Ronde Basalt section in the Salmon River area may have resulted from the regional synclinal structure that crossed the area (see Figure 11). The broad syncline acted as a trap for interbed forming material that originated in or entered the area during Grande Ronde time and is currently not exposed. This relationship is noted along its projected continuation with The Dalles-Mt. Hood syncline in the 01d Maid Flat area where $269 \mathrm{~m}$ of combined interbeded material is present within the Grande Ronde Basalt section (Priest, 1982b). Therefore, the lack of observed interbedded material probably resulted from the poor exposure of horizons where interbeds occur.

A locally distinct, carbonaceous coaly interbed $(0.5-1 \mathrm{~m}$ 
thick) in the upper Grande Ronde Basalt section marks the high$\mathrm{MgO} / \mathrm{low}-\mathrm{MgO}$ contact and is well exposed at the Salmon River quarry and the Brightwood quarry $2.4 \mathrm{~km}$ to the north. In the Hood River area, $25 \mathrm{~km}$ to the northeast, a $0.5 \mathrm{~m}$ thick coal seam is also located at the high-MgO/low-MgO contact ( $\mathrm{Timm}, 1979$ ). This does not require continuity between these localities but suggests that their surfaces formed closed depressions in response to the regional tectonic stresses that influenced the paleo-environment during that time.

Stratigraphic evidence of structural development throughout the Salmon River area is suggested by the decreased thickness of the upper low-MgO flow in the Salmon River quarry, the Brightwood and old county quarries. The variable thickness of the one to two flow high-MgO section within the Salmon River area suggests that deformation of the underlying surface took place prior to its incursion. The structure encountered by these flows was the gentle beginning of the northeast-trending fold system and its complementary $\mathrm{N} 30^{\circ} \mathrm{W}$ structural zone. Evidence of more rapid development along Copper Creek in the upper Salmon River exposure exists where high-Mg0 flows were apparently pinched out and excluded from the section.

The last high-Mg0 flows into the area marks the beginning of a quiescent period in the CRB incursion into the Salmon River area and represents the longest interval between basalt flows through the Cascades. During this period the Vantage interbed was formed by the accumulation of volcaniclastic sedimentary 
material in low relief areas with poor drainage on the basalt surface and by production of forests on adjacent relative highs.

In the Bull Run River area, and the Hood River area the Vantage interbed is commonly represented by up to $30 \mathrm{~m}$ of laterally continuous sedimentary material. Up to $30 \mathrm{~m}$ of sedimentary material occurs at the top of the Grande Ronde Basalt in the Clackamas River area, but this interbed is not overlain by Ginkgo basalt, and may have formed, or continued to form, after Vantage tıme (Beeson, personal communication, 1986).

The discontinuous, locally restricted nature of the Vantage interbed in the Salmon River area is typical of its occurrences throughout most of the Cascade Range and western Oregon (exclusive of the Bull Run River area). This interbed was observed in only three locations within the entire Salmon River area.

The Vantage interbed is represented near the mouth of Tumbling Creek by a discontinuous $0.5 \mathrm{~m}$ bed of silty mudstone. The Tumbling Creek interbed probably developed within a localized irregularity on the northern flank of the developing anticline to the east.

A regionally characteristic Vantage interbed is located along south Boulder Creek (S.W.1/4, N.W.1/4, sec. 36, T. 2 S., R. 6 E.) where 1.25 m of fine-bedded sandstone crops out. The absence of pillow structures and hyaloclastic material in the overlying flow suggests a lack of ponded water associated with the paleo-environment of the area. This interbed records 
structural development of the $\mathrm{N} 30^{\circ} \mathrm{W}$ structure that projects through the area. Uplift along the $\mathrm{N} 30^{\circ} \mathrm{W}$ structural zone during Vantage time formed an adjacent area of poor drainage to the west that accumulated the sedimentary material currently exposed in south Boulder Creek. The Vantage interbed is absent in two exposures of the Vantage horizon northeast of south Boulder Creek corresponding closely to the suggested location of the $\mathrm{N} 30^{\circ} \mathrm{W}$ structural zone.

In the southern edge of the Arrah Wanna area, the Vantage horizon is exposed with a single silicified log incorporated in the base of the overlying Ginkgo chemical type flow. The absence of a soil horizon suggests the area was continually uplifted. The log may have been carried a considerable distance from areas with well developed soils prior to being overlain.

Further evidence of structural development in the Salmon River area is the control that it had on the lateral distribution of the initial Frenchman Springs basalt flows. Flow distribution and thinning of the Ginkgo basalt provide evidence that the northeast-trending fold pattern was well developed by this time. The amount of uplift along the anticlinal features in the upper Salmon River exposure was sufficient to exclude the first two units of the Frenchman Springs Member. The development of the Tumbling Creek anticline is indicated by the onlapping nature of the Silver Falls unit, that pinched out along the southeastern limb near the mouth of Inch Creek approximately $2.4 \mathrm{~km}$ from the crest. 
The Ginkgo basalt and the Silver Falls basalt flows display a similiar relationship to the Copper Creek anticline, which may have developed more rapidly because of the apparent exclusion of high-MgO flows over its crest in the upper Copper Creek area. An intracanyon flow of the basalt of Ginkgo is believed to lie within the large synclinal structure south of Arrah Wanna (Beeson and others, 1985; Plate 2) that is currently not exposed. Projection of the Ginkgo intracanyon flow through this area is based on evidence of regional correlation and on mapped occurrences within western Oregon, the Cascades, and the Columbia Plateau.

Ginkgo basalt does not crop out in the Brightwood powerline section but probably exists beneath the valley floor. The area to the northwest was uplifted sufficiently to excluded the Ginkgo flows (and other Frenchman Springs flows) between the Brightwood quarry and the old county quarry. The thinning and pinching out of the Ginkgo basalt east of south Boulder Creek is a strong indication that some component of uplift was occurring along the $\mathrm{N} 30^{\circ} \mathrm{W}$ structural zone in that area. This is supported by nearby contact relations where Sentinel Gap flows rest directly on the noneroded surface of Ginkgo basalt in the absence of the Sand Hollow section. The prominent anticlinal fold in this area formed after Frenchman Springs time because of the uniform lateral thickness throughout the Brightwood section. If folding had occurred during Frenchman Springs time the upper flows would be expected to thin over the crest and thicken along the limbs. 
Infilling by the Ginkgo flows had little affect on the the structural paleo-relief indicated by the next unit to enter the area, the basalt of Silver Falls. The distribution pattern for Silver Falls basalt is similar to the preceeding Ginkgo basalt over which it flowed, continuing to infill and expand laterally against its structural confines. The single flow of Silver Falls basalt was apparently channeled into a northeast-trending fold system that inhibited its lateral spread and restricted its incursion to the upper Salmon River exposure.

Conclusions about the structural development of the area may be inferred from the combined relationships of the Frenchman Springs and Ginkgo basalts in the upper Salmon River area. If substantial uplift had occurred after incursion of the Ginkgo flows then it is probable that the relatively thin Silver Falls flow would pinch out against it. Since this flow spread laterally beyond the Ginkgo basalt and pinched out against the high-MgO structure, the likelihood is that little new structural development occurred during the interflow period. From these relationships, it appears that any relief that formed along the northeast-trending series of folds during this period of time was not sufficient for detection by this study.

The absence of Silver Falls basalt north of the upper Salmon River area suggests a regional barrier existed. The Silver Falls basalt flow is relatively thin, which indicates that as little as $40 \mathrm{~m}$ of paleo-relief could have successfully blocked its path. The effectiveness of the northeast-trending fold 
structures as a barrier was probably enhanced by the development and position of pathways to the south, providing a less resistant course for the Silver Falls basalt to advance through the Salmon River area.

The next youngest sequence of flows entering the Salmon River area belonged to the basalt of Sand Hollow. This unit flooded the area with the thickest accumulation of any Frenchman Springs chemical type. This is the most laterally continuous unit with respect to the Salmon River area. Its volume and number of flows coupled with infilling by early flows resulted in complete coverage of the area. The thickness variations within the Sand Hollow section indicate paleo-topography remained after partial infilling by the previous Frenchman Springs flows and is consistent with the structures already described. Sand Hollow basalt forms the top of the CRB section in the upper Salmon River exposure but was overlain by Sentinel Gap basalt in the north. The uniform distribution of the upper Sand Hollow section suggests a relatively low relief paleo-topography was formed across the entire Salmon River area. This observation is useful in helping to determine the development of post-Sand Hollow structures.

The development of the northeast-trending fold system is most evident during the late low-MgO to late Vantage time interval. Deformation was probably continuous throughout the incursion of the Frenchman Springs basalt, but because of the rapid succession of the post-Vantage flows, concurrent structural 
development is not discernable.

The final Frenchman Springs basalt to flow through the Salmon River area was a single flow belonging to the basalt of Sentinel Gap. It is restricted to the northern part of the Salmon River area and does not crop out in the upper Salmon River exposure. It is well exposed in the Brightwood, Salmon River quarry, and Alder Creek exposures where it crops out with a uniform lateral thickness throughout these sections. These characteristics are in direct contrast with the earlier Frenchman Springs flows of Ginkgo and Frenchman Springs basalt.

The exclusion of Sentinel Gap basalt from the entire upper Salmon River exposure, and the improbability that it could have been eroded so extensively, suggest that a barrier was present. It is probable that the earliest Rhododendron material had begun encroaching onto the tectonically depressed CRB surface to the south. These andesitic volcanic flows and debris flows are interbedded within the upper Frenchman Springs section in the 0ld Maid Flat area (Priest, 1982b) suggesting their influence in the area prior to Sentinel Gap time. The lack of Rhododendron material in the Frenchman Springs section that is exposed in the northern Salmon River area is not conclusive of their absence in the area. The synclinal area south of the Arrah Wanna exposure could have channeled the younger volcanic material and formed sufficient constructional relief to block the southern advance of the relatively thin Sentinel Gap flow. The possibility that uplift within this area was responsible for blocking the Sentinel 
Gap flow is considered unlikely because of the tendency for these features to currently be exposed as CRB highs.

The structures that formed during the time that CRB was flowing into the area consisted of $\mathrm{N} 30^{\circ} \mathrm{W}$ faults with strike slip and normal faulting, which may be concentrated along the western edge of the area in a structural zone and a concurrently forming $\mathrm{N} 50^{\circ}-80^{\circ}$ E-trending fold system. Structures that formed during post-CRB time are best defined by offset of the Sand Hollow basalt, which is believed to have covered the Salmon River area with a smooth continuous upper surface. The post-CRB tectonic regime formed thrusts, high-angle reverse faults, largescale folding, and normal faulting and is responsible for the largest degree of stratigraphic offset and displacement seen today. The top of the Sand Hollow surface has been displaced rough1y $122 \mathrm{~m}$ by the Tumbling Creek thrust. The Arrah Wanna thrusts, which may show even greater displacement, is so complicated that the actual amount could not be determined. The degree of displacement at this location is complicated by the $\mathrm{N}$ $30^{\circ} \mathrm{W}$ structural zone.

The post-CRB timing of the Copper Creek reverse faults in the upper Salmon River area is determined by the uniform thickness of Sand Hollow flows across the structure. The ridge containing the Brightwood quarry, and to the west, has been equated with a structural high during most of Frenchman Springs time determined by the complete exclusion of post-Vantage flows. Therefore, the Frenchman Springs flows do not help determine the 
age of the Brightwood exposure high-angle, reverse fault. The reverse fault noted here could also have been formed during post$\mathrm{CRB}$ by association and similarity with the Copper Creek reverse faults.

Much of the post-CRB structural development was formed by a stress field similar to that responsible for the previous CRB deformation. The difference in the types of structures that were formed by similar regional stresses through time may be attributed to the behavior of different thicknesses of material. A thick layer of material will behave differently than a thin layer of similar material when compressed, all other factors being equal (Hobbs and others, 1976). This difference is the wave-length of initial folding, which increases with increasing thickness. Early deformation in the Salmon River area resulted in a sequence of northeast-oriented fold axes that are reflected by the surface of the Grande Ronde Basalt. Infilling of the area by Frenchman Springs flows increased the overall basalt thickness by 50-100 m over the entire area. Continued tectonic forces now acting on a more rigid $C R B$ body may have resulted in a greater amplitude of folding in addition to concurrent movement along previously existing folds. This was eventually accompanied by thrusting and high-angle reverse faulting. The anticlinal axis located beneath the Brightwood powerline was formed during this time period in conjunction with the High-angle reverse fault to the northwest. 
Regional tectonic activity was responsible for the production of localized andesitic volcanic centers (Beeson and Moran, 1979b). This volcanic activity resulted in the formation of the Rhododendron material and later the Mt. Hood volcano. Coarse-grained dioritic intrusive sills were injected between flows of low-MgO Grande Ronde Basalt and Sand Hollow basalt at two separate locations in the upper Salmon River exposure. Local intrusions into the CRB section, the Still Creek pluton $5.6 \mathrm{~km}$ to the northeast (sec. 29, T. 3 S., R. 8 E.), and the Mt Hood volcano, attest to the presence of actively producing magma chambers at relatively shallow depths and their proximity to the Salmon River area. The tectonic forces associated with these magma bodies could have caused localized variations in the regional stress field and the differential uplift of CRB seen throughout the Salmon River area. These forces and the increased thickness of the basalt during its deformational history, could have aided formation of the sequence of structures that developed in the Salmon River area.

A northwest-trending fault exposed in the Brightwood quarry, has a right-lateral strike-slip last sense of motion, but up to $10 \mathrm{~m}$ of normal displacement is apparent. Movement along this fault is associated with early structural deformation. The earliest deformation along the $\mathrm{N} 30^{\circ} \mathrm{W}$ structural zone is also related to this period by stratigraphic controls observed in the Frenchman Springs section across its trend. 
Regional displacement associated with the $\mathrm{N} 30^{\circ} \mathrm{W}$ fault zone is predominently right-lateral strike-slip (Beeson and Moran, 1979b). This study suggests local senses of movement along the $\mathrm{N} 30^{\circ} \mathrm{W}$ structural zone (in the Salmon River area) was caused by folded CRB to the northeast during, and after its time of incursion. The sense of movement along the $\mathrm{N} 30^{\circ} \mathrm{W}$ structural zone had components of strike slip and normal displacement. Anticlinal structures terminating against the zone would display an uplifted relationship (Figure 14). This study concludes that regional strike-slip and local vertical displacement occurred simultaneously and were caused by fold structures in the northeastern block. Thus, vertical displacement along the $\mathrm{N} 30^{\circ}$ W- trending structural zone does not suggest northeast-southwest extensional forces that would not $f$ it the currently proposed tectonic model.

Evidence of the $\mathrm{N} 30^{\circ} \mathrm{W}$ structural zone projected to the south was observed in Tumbling Creek where the CRB is faultterminated to the west along a $\mathrm{N} 42^{\circ} \mathrm{W}$ trend. Northwest-trending breccia zones are exposed in a structurally complicated exposure along the South Fork Salmon River, further indicating continuation of the $\mathrm{N} 30^{\circ} \mathrm{W}$ zone to the south.

Northeast-trending normal faults are the youngest structures recorded by the deformational history of the CRB in the Salmon River area. These structures suggest the demise of the northwest compressional tectonic regime responsible for previous structures. Associated stresses may have resulted from 
Cascadian uplift during recent volcanic episodes throughout the area. Local variations in the stress field are probably influenced by near surface-magmas indicated by intrusions into the CRB section and adjacent intrusive bodies to the northeast. 
CHAPTER V

\section{DISCUSSION AND CONCLUSIONS}

The framework of this study was based on detailed mapping and stratigraphic sampling of the CRBG exposed in the Salmon River area, Oregon. The stratigraphic relations were confirmed with chemical analyses by INAA for trace elements and by $x$-ray fluorescence spectroscopy for major-oxide composition on 166 samples collected from throughout the area. Approximately $134 \mathrm{~m}$ of basalt is exposed in structurally interrupted outcrops isolated by thick accumulations of overlying, locally produced volcanic material of the Rhododendron Formation. The entire CRB section belongs to the Yakima Basalt Subgroup and may be further divided into Grande Ronde Basalt and Wanupum Basalt.

Flows of Grande Ronde Basalt were the first CRB to enter the area as they proceeded west through the Cascade Range from the Columbia Plateau. At least six flows of this chemical type are present. A geochemical break in the section was mapped based on contrasting MgO content. This horizon separates the four underlying low-MgO Grande Ronde Basalt flows from the upper two high-MgO flows. One flow of the Prineville chemical type is interbedded in the low-MgO section. Except for one brief structurally exposed segment of the N2/R2 boundary, the Grande 
Ronde Basalt section represents a single (N2) paleo-magnetic episode. A possible $300-400 \mathrm{~m}$ of basalt may exist in the Salmon River area beneath the surface of exposure.

The Vantage horizon, which marks the top of the Grande Ronde Basalt section, represents a quiescent period in the succession of CRBG flows into the area. It is typically distinguished regionally by the sedimentary material called the Vantage interbed that accumulated during this time. This interbed was observed at only three locations in the Salmon River area and can be described as thin discontinuous sedimentary beds of varied composition and environments of deposition.

The end of Vantage time in the Salmon River area is represented by incursion of the Frenchman Springs Member basalt flows. The Frenchman Springs basalt section is $134 \mathrm{~m}$ thick (maximum) and consists of eight flows that may be divided into four distinct chemical units (Beeson and others, 1985). These are (oldest to youngest) basalt of Ginkgo, basalt of Silver Falls, basalt of Sand Hollow, and basalt of Sentinel Gap. Contact relations suggest distribution of these basalts throughout the area was affected and controlled by the irregular surface of the Grande Ronde Basalt over which they flowed. The Ginkgo and Silver Falls chemical units are laterally discontinuous and pinch out against structural highs in the paleo-topography. Silver Falls basalt is restricted to the upper Salmon River exposure. Flows of Sand Hollow basalt crop out in all the major exposures (except in the south fork exposure; see 
Figure 3) suggesting they completely infilled the topography and formed a continuous sheet throughout the Salmon River area. The Sentinel Gap chemical type is restricted to the northern part of the Salmon River area as a thin, laterally continuous flow unit. The ubiquitous nature of the Grande Ronde Basalt reflects the low relief topography that existed during its incursion. Prior to high-MgO time a northwest-southeast-compressional northeast-southwest-extentional regional stress field originated. This stress field resulted in a series of $\mathrm{N} 50^{\circ}-80^{\circ} \mathrm{E}$ fold axes that were responsible for the irregular distribution of subsequent Frenchman Springs basalt.

A predominently $\mathrm{N} 30^{\circ} \mathrm{W}$ structural zone developed along the western edge of the Salmon River area in response to the regional compressive stresses. The regional strike-slip nature of this zone was masked by folds in the CRB comprising the northeastern block. The en-echelon pattern of northeast-trending folds appears to terminate at the boundary of the $\mathrm{N} 30^{\circ} \mathrm{W}$ structural zone. The folds that terminated against the $\mathrm{N} 30^{\circ} \mathrm{W}$ structural zone caused the vertical displacement noted along this trend in the Salmon River area (Figure 14). A previous zone of weakness may have existed there but it was overprinted by the subsequent structures that developed.

Structural development during the incursion of Frenchman Springs basalt is not detected by the contact relations of these flows, which rapidly infilled lows in the topography and formed a flat-lying surface of basalt in the Salmon River area. 


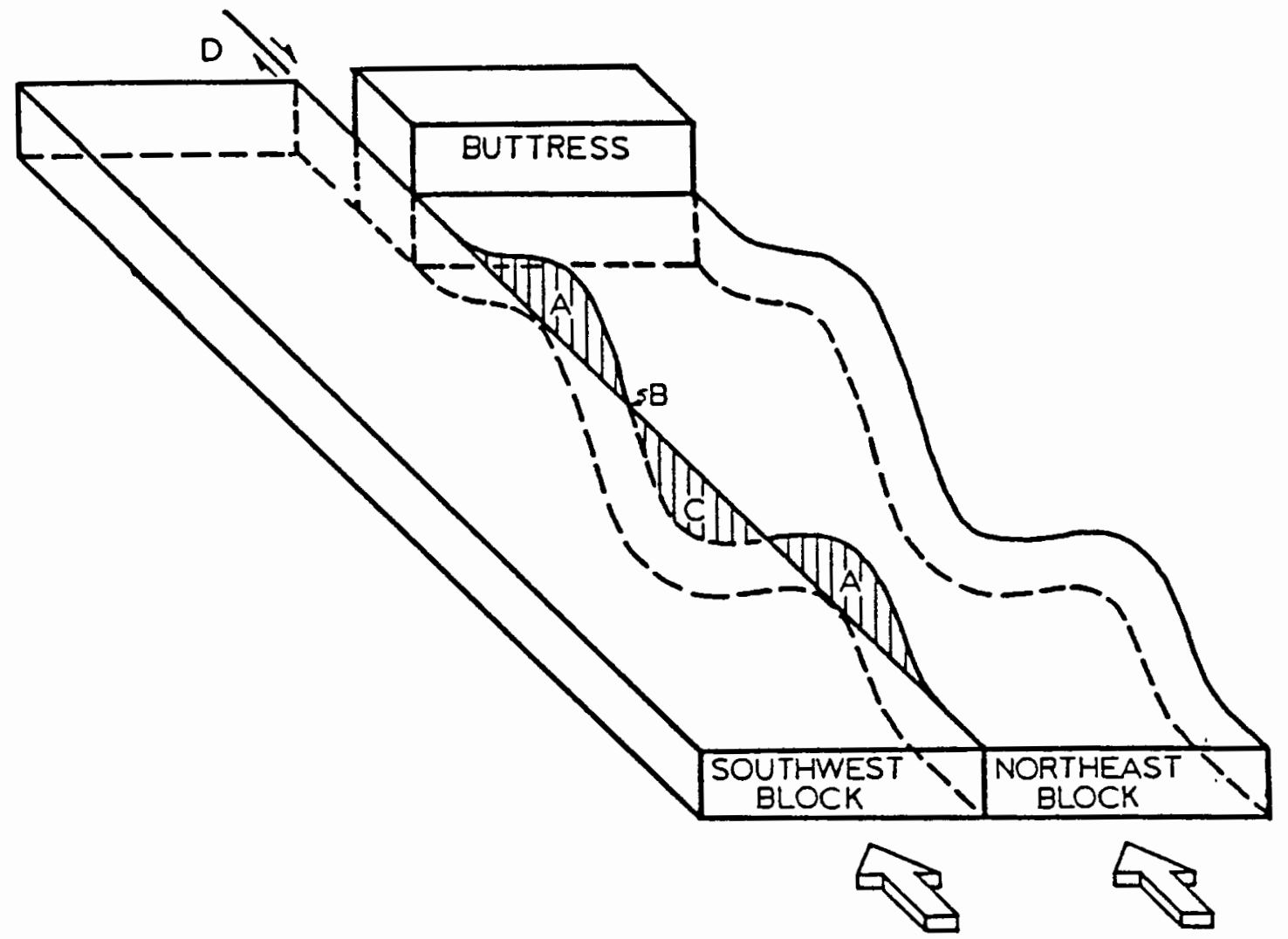

FIGURE 14. Diagram illustrating the relative senses of movement between the $\mathrm{N} 30^{\circ} \mathrm{W}$ structural zone and the folded northeastern block; $A=$ area of upward displacement by the eastern block (well exposed; $B=$ area of strike-slip movement and no apparent vertical displacement (generally not exposed); $C=$ area of downward displacement by the eastern block (not exposed); $D=$ regional sense of motion along the $\mathrm{N} 30^{\circ} \mathrm{W}$ structural zone 
Continuation of essentially the same stress field during post CRB time, resulted in progressive folding, thrusting, and high-angle reverse faulting along previously formed structural trends. These structures are consistent with a regional tectonic model of northwest-southeast-compression and northeast-southwestextension, that is suggested by this study and has been consistently supported by previous studies in the northern Cascades of Oregon.

Variation in the structures that formed through time from a similar stress field is attributed to continual length-shortening of the relatively brittle CRB section.

Late forming normal faults represent northeast-southeasttrending noncompressional type structures. They are the youngest structures in the Salmon River area and may be related to broad uparching of the Cascade Range during High Cascade volcanism. Local fluctuations in the stress field may have resulted from near surface magmatic activity that intruded the CRB section and formed large silicic plutonic bodies adjacent to the Salmon River area and throughout the northern Cascade Range. Normal faults suggest a lapse in the overall regional stress field and represent the youngest structures recorded by the tectonic history of the CRB in the Salmon River area, Oregon. 


\section{REFERENCES CITED}

Anderson, J. L., 1978, The stratigraphy and structure of the Columbia River basalt in the Clackamas River drainage:

Portland, Oregon, Portland State University master's thesis, $136 \mathrm{p}$.

Asaro, F., Michel, H. V., and Meyers, C.W., 1978, A statistical evaluation of some Columbia River basalt chemical analyses: Richland, Wash., Rockwell Hanford Operations RHO-BWI-ST-3, $62 \mathrm{p}$.

Baksi, A. H., and Watkins, N. D., 1973, Volcanic production rates: comparison of ocean ridges, islands, and the Columbia Plateau basalts: Science, v. 180, p. 493-496.

Baldwin, E. W., 1981, Geology of Oregon: 3rd ed., Kendall Hunt pub., $170 \mathrm{p}$.

Beeson, M H., Fecht, K R., Reidel, S P., Tolan, T L., 1985, Regional Correlations within the Frenchman Springs Member of the Columbia River Basalt Group: New insights into the middle Miocene tectonics of northwestern Oregon: Oregon Geology, v. 47, no. 8, p. 89-96.

Beeson, M. H., Johnson, A. G., and Moran, M. R., 1975, Portland, Oregon, Portland State University, $107 \mathrm{p}$.

Beeson, M. H., and Moran, M. R., 1979a, Columbia River Basalt Group stratigraphy in western Oregon: Oregon Geology, v. 41, no. 1, p. 11-14.

1979b, Stratigraphy and structure of the Columbia River Basalt Group in the Cascade Range, Oregon, in Riccio, J. F., ed., Geothermal resource assessment of Mount Hood: Oregon Department of Geology and Mineral Industries Open-File Report 0-79-8, p.5-77.

Beeson, M. H., Moran, M. R., Anderson, J. L., Vogt, B. F., 1982, The relationship of the Columbia River Basalt Group to the geothermal potential of the Mount Hood area, Oregon, in Priest, G. R., and Vogt, B. F. eds., Geology and geothermal resources of the Mount Hood area, Oregon: Oregon Department of Geology and Mineral Industries Special Paper 14, p. 43-46

Beeson, M. H., Moran, M. R., O1son, F. L., 1976, Geochemical data on Columbia River basalt stratigraphy in western Oregon: Geological Society of America Abstracts with Programs, v. 8, no. 3, p. 354 . 
Beeson, M. H., Moran, M. R., Vogt, B. F., 1982, The Relationship of the Columbia River Basalt Group to the Geothermal

Potential of the Mount Hood Area, Oregon: Oregon Department of Geology and Mineral Industries Special Paper No. 14, p. 43-46

Beeson, M. H., Perttu, R., and Perttu, J., 1979, The origin of the Miocene basalts of coastal Oregon and Washington: Oregon Geology, v. 41, no. 10, p. 159-166

Bentley, R. D., 1977, Stratigraphy of Yakima Basalts and structural evolution of the Yakima ridges in the western Columbia Plateau, in Brown, E. H., and Ellis, R. C., eds., Geologic excursions in the Pacific Northwest: Bellingham, Wash., Western Washington University Department of Geology, p. 339-389.

Bingham, J. W., Grolier, M. J., 1966, The Yakima Basalt and Ellensburg Formation of south-central Washington: United States Geologic Survey Bulletin 1224-G, 15 p.

Bond, J. G., 1963, Geology of the Clearwater embayment: Idaho Bureau of Mines and Geology Pamphlet 128, 83 p.

Bond, J. G., Kauffman, J. D., Venkatakrishnan, R., 1980, Geologic linears of the Northern Part of the Cascade Range, Oregon: Oregon State Department of Geology and Mineral Industries Special Paper no. 12, 25 p.

Choiniere, S. R., and Swanson, D. A., 1979, Magnetostratigraphy and correlation of Miocene basalts of the northern Oregon coast and Columbia Plateau, southeast Washington: American Journal of Science, v. 279, p. 755-777.

Flanagan, F. J., 1976, Descriptions and analyses of eight new USGS rock standards: United States Geologic Survey Professional Paper 840, 192 p.

Flannagan, G., and Williams, D. L., 1982, A magnetic investigation of Mt Hood, Oregon: Journal of Geophysical Research. B, v. 87, n. 4, p. 2804-2814.

Hammond, P. E., 1979, A tectonic model for evolution of the Cascade Range, in Armentrout, J. M., Cole, M. R., and Terbest, H., Jr., eds., Cenozoic paleogeography of the western United States: Pacific Section, Society of Economic Paleontologists and Mineralogists, p. 219-237.

Holden, G. S., and Hooper, P. R., 1976, Petrology and chemistry of a Columbia River basalt section, Rocky Canyon, westcentral Idaho: Geologic Society of America Bul1., v. 87, p. 215-225. 
Holmgren, D. A., 1970, K/Ar dates and paleomagnetics of the type Yakima Basalt, central Washington, in Gilmour, E. H., and Stradling, D., eds., Proceedings of the Second Columbia River Basalt Symposium: Cheney, Washington, Eastern Washington State College Press, p. 201-207.

Hooper, P. R., 1974, Petrology and chemistry of the Rock Creek flow, Columbia River basalt, Idaho: Geologic Society of America Bu11., v. 85, p. 15-26.

Hooper, P. R., Knowles, C. R., and Watkins, N. D., 1979, Magnetostratigraphy of the Imnaha and Grande Ronde Ronde Basalts in the southeast part of the Columbia Plateau: American Journal of Science, v. 279, p. 737-754.

Kohler, W. M., Healy, J. H., Wegener, S. S., 1982, Upper crustal structure of the Mount Hood region, Oregon, as revealed by time term analysis: Journal of Geophysical Research, v. 87, p. 339-355.

Ledgerwood, R. K., Brown, D. J., Waters, A. C., and Meyers, C. W., 1973, Identification of Yakima Basalt flows in the Pasco Basin: Atlantic Richfield Hanford Company, U. S. Atomic Energy Commission Report ARH-2768.

Mackin, J. H., 1961, A stratigraphic section in the Yakima Basalt and the Ellensburg Formation in south-central Washington: Washington Division of Mines and Geology Report Inv. 19, 45 p.

McKee, E. H., Swanson, D. A., and Wright, T. L., 1977, Duration and volume of Columbia River basalt volcanism, Washington, Oregon, and Idaho: Geologic Society of America Abstracts with Programs, v. 9, no. 4, p. 463-464.

Nathan, S., and Fruchter, J. S., 1974, Geochemical and paleomagnetic stratigraphy of the Picture Gorge and Yakima Basalts (Columbia River Group) in central Oregon: Geologic Society of America Bulletin, v. 85, p. 63-76.

Osawa, M., and Goles, G. G., 1970, Trace element abundances in Columbia River basalt, in Gilmour, E. H., and Stradling, D., eds., Proceedings of the Second Columbia River Basalt Symposium: Cheney, Washington, Eastern Wahsington State College Press, p. 55-71.

Peck, D. L., Griggs, A. B., Schlicker, H. G., Wells, F. G., and Dole, H. M., 1964: United States Geologic Survey

Professional Paper, n. 449, 56 p. 
Preist, G. R., 1982a, Overview of the geology and geothermal resources of the Mt Hood area: Oregon Department of Geology and Mineral Industries, Special Paper 14, p. 6-14.

----1982b, Geology, geochemistry and geothermal resources of the 01d Maid Flat area, Oregon: Oregon Department of Geology and Mineral Industries, Special Paper 14, p. 16-30.

Reidel, S. P., Long, P. E., Myers, C. W., and Mase, J., 1982, New evidence for greater that $3.2 \mathrm{~km}$ of Colunbea River basalt beaneath the Central Columbia Plateau: EOS (American Geophysical Union Transactions), v. 84, p.173.

Russe11, I. C., 1901, Geology and water resources of Nez Perce county, Idaho: U. S. Geological Survey Water-Supply Papers $53-54,141 \mathrm{p}$.

Schmincke, H. U., 1967, Stratigraphy and petrography of four upper Yakima Basalt flows in South-central Washington: Geologic Society of America Bul1., v. 78, p. 1385-1422.

Seims, B. A., Bush, J. H., and Crosby, J. W., III, 1974, TiO2 and geophysical logging criteria for Yakima Basalt correlation, Columbia Plateau: Geologic Society of America Bull., v. 85, p. 1061-1068.

Smith, G. A., 1986, Stratigraphy, Sedimentology, and Petrology of Neogene Rocks in the Deschutes Basin, Central Oregon: A Record of Continental-Margin Volcanism and its Influence on Fluvial Sedimentation in an Arc-Adjacent Basin: Corvallis Oregon, Oregon State University Doctoral Dissertation, 467 p.

Smith, G. 0., 1901, Geology and water resources of a portion of Yakima County, Washington: U. W. Geologic Survey WaterSupply Paper 55, 68 p.

Swanson, D. A., 1967, Yakima Basalt of the Tieton River area, south-central Washington: Geological Society of America Bulletin, v. 78, p. 1077-1110.

Swanson, D. A., 1981, Guide to geologic field trips between Lewiston, Idaho and Kimberly, Oregon, emphasizing the Columbia River Basalt Group, in Johnston, D. A., and Donnelly-Nolan, J., eds., 1981, Guides to some volcanic terranes in Washington, Idaho, Oregon, and northern California: United States Geologic Survey Circular 838, p. $1-28$. 
Swanson, D. A., and Wright, T. L., 1976, Magnetostratigraphic units in the Yakima Basalt, southeast Washington:

Geological Society of America Abstracts with Programs, v. 8, no. $3, \mathrm{p} .413$.

Swanson, D. A., Wright, T. L., and Helz, R. T., 1975, Linear vent systems and estimated rates of magma production and eruption for the Yakima Basalt on the Columbia Plateau: American Journal of Science, v. 275, p.877-905.

Swanson, D. A., Wright, T. L., Hooper, P. R., and Bently, R. D., 1979, Revisions in stratigraphic nomenclature of the Columbia River Basalt Group: U. S. Geologic Survey Bulletin $1457-\mathrm{G}, 59 \mathrm{p}$.

Taubeneck, W. H., 1970, Dikes of Columbia River Basalt in northeastern Oregon, western Idaho, and southeastern Washington, in Gilmour, E. H., and Stradling D., eds., Proceedings of the second Columbia River Basalt symposium: Cheney, Washington, Eastern Washington State College Press, p. 73-96.

Timm, S., 1979, The structure and stratigraphy of the Columbia River basalt in the Hood River Valley, Oregon: Portland, Oregon, Portland State University master's thesis, 60 p.

Uppuluri, V. R., 1974, Prineville chemical type: a new basalt type in the Columbia River Group: Geologic Society of America Bul1., v. 85, p. 1315-1318.

Vogt, B. F., 1981, The stratigraphy and structure of the Columbia River basalts in the Bullrun River drainage, Oregon:

Portland Oregon, Portland State University master's thesis, $211 \mathrm{P}$.

Waters, A. C., 1961, Stratighic and lithologic variations in the Columbia River basalt: American Journal of Science, v. 259, p. 583-611.

Waters, A. C., 1962, Basalt magma types and their tectonic association--Pacific Northwest of the united States: American Geophysical Union Mon. 6, p. 158-170.

Watkins, N. D., and Baski, A. K, 1974, Magnetostratigraphy and oroclinal folding of the Columbia River. Steens, and Owyhee basalts in Oregon, Washington, and Idaho: American Journa1 of Science, v. 274, p. 148-189.

Wells, F. G., and Peck, D. L., 1961, Geologic map of Oregon west of the 121 st meridian: U. S. Geologic Survey Miscellaneous Investigations Map I-325, scale 1:5000,000. 
Williams, D. L., Hull, D. A., Ackerman, H. D., Beeson, M. H., 1982, The Mt Hood Region: volcanic history, structure, and geothermal energy potential: Journal of Geophysical Research, v. 87, no. B4, p. 2767-2781.

Wise, W. S., 1969, Geology and petrography of the Mount Hood area: a study in High Cascade volcanism: Geological Society of America Bull., v. 80, p. 969-1006.

Wright, T. L., Grolier, M. J., and Swanson, D. A., 1973, Chemical variation related to the stratigraphy of the Columbia River basalt: Geological Society of America Bull., v. 84, p. 371386. 
APPENDIX A

SLMMARY OF MAJOR OXIDE COMPOSITION FOR LOWMOO GRANDE RONDE BASALT

\begin{tabular}{|c|c|c|c|c|c|c|c|c|c|c|}
\hline EIEMENT & $\mathrm{Si}$ & $\mathrm{Al}$ & $\mathrm{Ti}$ & *Fe & M & $\mathrm{Ca}$ & $\mathrm{Mg}$ & $\mathrm{K}$ & $\mathrm{Na}$ & $P$ \\
\hline SAMPLE & \multicolumn{10}{|c|}{ WHOLE ROCK WIEGHT PERCENT OF ELIMENT IN OXTDE FORM } \\
\hline $77-B 2$ & 55.79 & 14.91 & 2.21 & 10.34 & 0.20 & 6.89 & 3.44 & 1.39 & 2.48 & 0.33 \\
\hline $713-B$ & 55.51 & 15.08 & 2.17 & 10.13 & 0.18 & 6.77 & 3.60 & 1.53 & 2.70 & 0.33 \\
\hline $713-c$ & 54.95 & 14.91 & 2.11 & 10.53 & 0.21 & 7.14 & 3.76 & 1.63 & 2.45 & 0.32 \\
\hline $715-D$ & 54.68 & 15.02 & 2.19 & 10.52 & 0.20 & 7.61 & 4.04 & 0.69 & 2.70 & 0.34 \\
\hline $715-G$ & 55.68 & 15.18 & 2.07 & 10.04 & 0.19 & 7.41 & 3.70 & 0.82 & 2.60 & 0.31 \\
\hline $715-\mathrm{H}$ & 54.75 & 14.80 & 2.27 & 10.83 & 0.21 & 7.08 & 3.76 & 1.41 & 2.54 & 0.35 \\
\hline $715-I$ & 55.74 & 14.73 & 2.18 & 10.48 & 0.21 & 7.05 & 3.35 & 1.45 & 2.47 & 0.33 \\
\hline $722-A$ & 54.85 & 14.75 & 2.16 & 10.66 & 0.22 & 6.98 & 3.80 & 1.47 & 2.80 & 0.33 \\
\hline $722-I$ & 54.87 & 14.75 & 2.26 & 10.37 & 0.21 & 7.17 & 3.60 & 1.73 & 2.69 & 0.34 \\
\hline $723-B$ & 55.19 & 14.76 & 2.19 & 10.72 & 0.21 & 6.72 & 3.52 & 1.54 & 2.81 & 0.33 \\
\hline $730-E$ & 55.55 & 15.02 & 2.07 & 9.79 & 0.19 & 7.14 & 3.60 & 1.52 & 2.81 & 0.31 \\
\hline 731-A & 55.73 & 15.08 & 2.06 & 9.70 & 0.18 & 6.79 & 3.58 & 1.68 & 2.89 & 0.32 \\
\hline $731-C$ & 54.78 & 14.66 & 2.30 & 11.10 & 0.21 & 7.10 & 3.49 & 1.31 & 2.69 & 0.35 \\
\hline 731-D & 55.38 & 14.70 & 2.20 & 10.52 & 0.21 & 7.24 & 3.45 & 1.47 & 2.48 & 0.34 \\
\hline 731-E & 54.99 & 14.79 & 2.22 & 10.63 & 0.22 & 7.53 & 3.74 & 0.78 & 2.75 & 0.35 \\
\hline $813-\mathrm{A}$ & 56.03 & 15.33 & 2.10 & 9.05 & 0.21 & 7.38 & 3.97 & 1.14 & 2.48 & 0.31 \\
\hline $813-B$ & 56.98 & 15.63 & 2.04 & 7.74 & 0.18 & 7.47 & 4.02 & 1.19 & 2.45 & 0.30 \\
\hline $912-C$ & 55.37 & 14.74 & 2.20 & 10.75 & 0.21 & 7.20 & 3.36 & 1.41 & 2.43 & 0.33 \\
\hline AWCK-9 & 55.57 & 15.20 & 2.12 & 10.07 & 0.19 & 7.04 & 3.67 & 1.30 & 2.53 & 0.31 \\
\hline AWCX-11 & 55.06 & 15.02 & 2.48 & 10.59 & 0.17 & 6.67 & 3.65 & 1.49 & 2.34 & 0.34 \\
\hline ALCK-15 & 55.24 & 14.97 & 2.44 & 10.22 & 0.19 & 7.04 & 3.67 & 1.79 & 2.11 & 0.33 \\
\hline AVERAGE & 55.37 & 14.95 & 2.19 & 10.23 & 0.20 & 7.12 & 3.66 & 1.37 & 2.58 & 0.33 \\
\hline & 0.54 & 0.24 & 0.11 & 0.73 & 0.01 & 0.26 & 0.20 & 0.30 & 0.19 & 0.01 \\
\hline
\end{tabular}

* Fe content listed is $\mathrm{FeO}$; Fe203 assumed to be 2.00\%

* Standard deviation for calculated averages \pm 1 sigma 


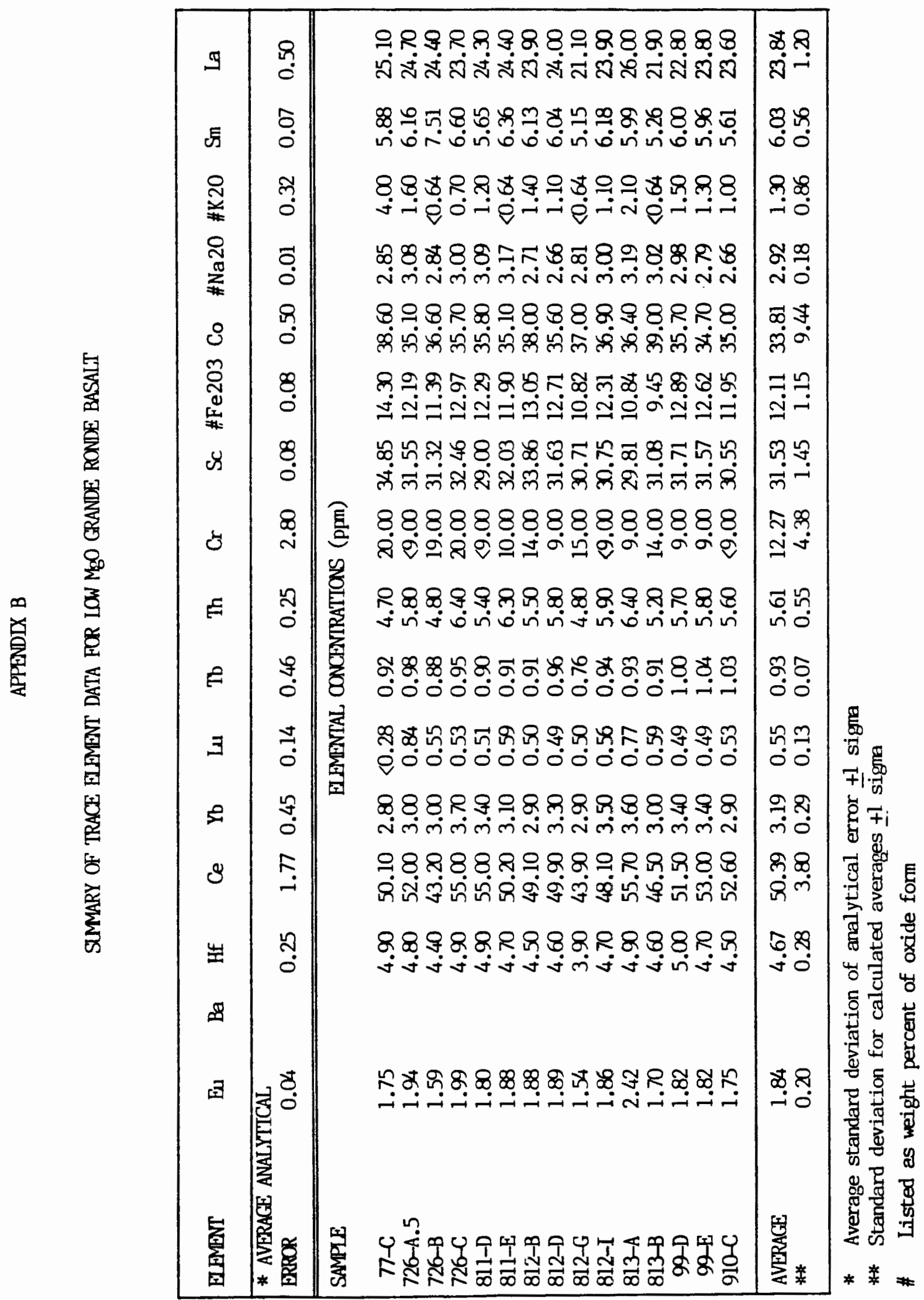


APPENDDX C

SUMMARY OF MANOR OXIDE COMPOSITON FOR HIGHMOO GRANDE RONDE BASALT

\begin{tabular}{|c|c|c|c|c|c|c|c|c|c|c|}
\hline EJEMENT & $\mathrm{Si}$ & Al & $\mathrm{Ti}$ & $\mathrm{Fe}$ & Mn & $\mathrm{Ca}$ & $\mathrm{Mg}$ & $\mathrm{K}$ & $\mathrm{Na}$ & $\mathrm{P}$ \\
\hline SAMPLE & \multicolumn{10}{|c|}{ WHOIE ROCK WIEGGT PERCENT OF EIEMENT IN OXIDE FORM } \\
\hline $713-A$ & 53.90 & 15.07 & 2.01 & 10.19 & 0.19 & 8.14 & 4.84 & 1.01 & 2.35 & 0.29 \\
\hline $715-B$ & 53.79 & 14.85 & 2.03 & 10.17 & 0.21 & 8.75 & 4.80 & 0.43 & 2.68 & 0.30 \\
\hline $715-C$ & 53.76 & 14.98 & 2.03 & 9.82 & 0.21 & 8.53 & 4.91 & 0.89 & 2.58 & 0.29 \\
\hline $715-\mathrm{J}$ & 53.72 & 14.99 & 2.06 & 10.24 & 0.20 & 8.47 & 4.85 & 0.64 & 2.53 & 0.30 \\
\hline $722-B$ & 53.58 & 14.91 & 2.02 & 10.14 & 0.20 & 8.42 & 4.88 & 0.93 & 2.63 & 0.30 \\
\hline $722-C$ & 53.57 & 14.89 & 2.05 & 10.10 & 0.21 & 8.51 & 4.76 & 1.00 & 2.61 & 0.31 \\
\hline $722-D$ & 53.71 & 15.09 & 1.89 & 9.75 & 0.20 & 8.68 & 5.07 & 0.98 & 2.35 & 0.28 \\
\hline $722-F$ & 53.69 & 15.06 & 1.90 & 9.48 & 0.19 & 8.59 & 5.11 & 1.08 & 2.62 & 0.28 \\
\hline $722-G$ & 53.62 & 15.03 & 2.04 & 9.69 & 0.23 & 8.61 & 4.96 & 1.06 & 2.46 & 0.31 \\
\hline $722-\mathrm{H}$ & 53.62 & 14.95 & 2.05 & 9.87 & 0.20 & 8.41 & 4.86 & 0.91 & 2.82 & 0.31 \\
\hline $724-C$ & 53.67 & 14.99 & 2.06 & 9.96 & 0.19 & 8.12 & 5.01 & 1.02 & 2.69 & 0.30 \\
\hline $731-B$ & 54.47 & 15.54 & 2.19 & 9.60 & 0.24 & 8.29 & 4.00 & 0.72 & 2.64 & 0.33 \\
\hline $99 \mathrm{~A}$ & 53.80 & 15.06 & 1.91 & 9.39 & 0.24 & 9.11 & 5.04 & 0.78 & 2.41 & 0.26 \\
\hline $99-\mathrm{B}$ & 54.56 & 15.07 & 2.02 & 9.60 & 0.21 & 8.71 & 4.77 & 0.56 & 2.19 & 0.30 \\
\hline 911-A & 54.06 & 14.92 & 2.05 & 10.22 & 0.21 & 8.55 & 4.40 & 0.71 & 2.59 & 0.30 \\
\hline $911-B$ & 53.83 & 15.29 & 1.94 & 9.33 & 0.21 & 9.14 & 5.20 & 0.51 & 2.29 & 0.27 \\
\hline 911-I & 53.79 & 15.17 & 1.93 & 9.30 & 0.21 & 9.27 & 5.25 & 0.45 & 2.37 & 0.26 \\
\hline 912-D & 53.61 & 15.08 & 2.05 & 10.25 & 0.21 & 8.69 & 4.76 & 0.71 & 2.34 & 0.30 \\
\hline AWCK-3 & 54.22 & 15.10 & 2.05 & 9.89 & 0.19 & 8.32 & 4.64 & 0.89 & 2.40 & 0.29 \\
\hline AWCK-7 & 53.93 & 14.91 & 2.09 & 10.20 & 0.20 & 8.32 & 4.73 & 0.91 & 2.41 & 0.31 \\
\hline & 2. & 15. & 2.02 & 9.86 & 0.21 & 8.58 & 4.84 & 0.81 & 2.50 & 0.29 \\
\hline & 0.28 & 0.16 & 0.07 & 0.33 & 0.01 & 0.31 & 0.28 & 0.21 & 0.16 & 0.02 \\
\hline
\end{tabular}

* Fe content listed is $\mathrm{FeO}$; $\mathrm{Fe} 203$ assumed to be $2.00 \%$

* Standard deviation for calculated averages \pm 1 sigma 


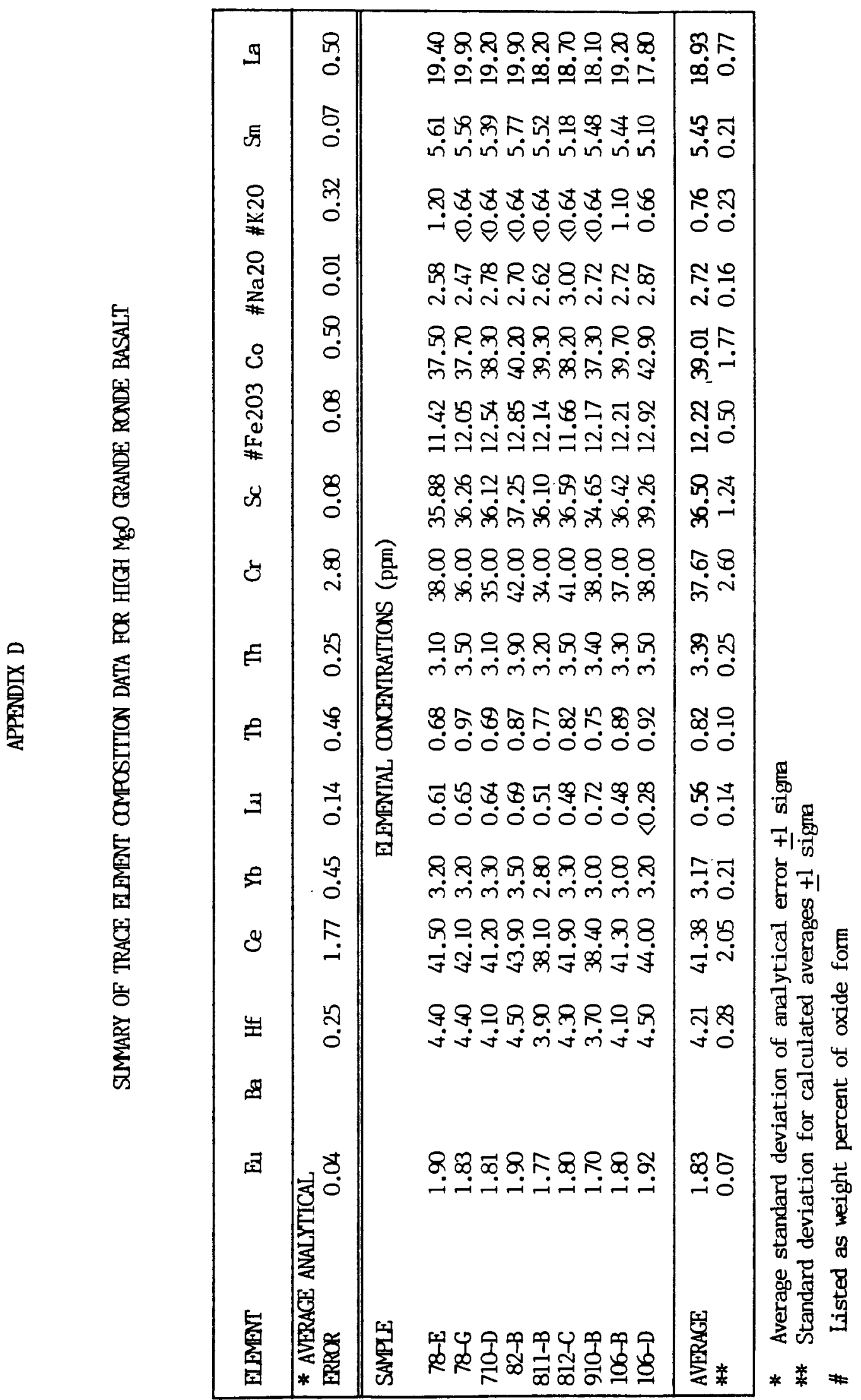


APPENDIX E

SLMMARY TABLE OF MAJOR OXIDE COMPOSITION FOR BASALT OF GINKCO

\begin{tabular}{|c|c|c|c|c|c|c|c|c|c|c|}
\hline ELPMENT & Si & $\mathrm{Al}$ & $\mathrm{Ti}$ & $* \mathrm{Fe}$ & Mn & $\mathrm{Ca}$ & $\mathrm{Mg}$ & $\mathrm{K}$ & $\mathrm{Na}$ & $P$ \\
\hline SAMPLE & \multicolumn{10}{|c|}{ WHOLE ROCX WIEGHT PERCENT OF ELEMENT IN OXIDE FOPM } \\
\hline $710-B$ & 52.13 & 14.12 & 3.12 & 12.37 & 0.23 & 8.18 & 4.34 & 0.71 & 2.20 & 0.60 \\
\hline $722-E$ & 51.95 & 14.08 & 3.12 & 12.53 & 0.21 & 7.79 & 4.30 & 1.10 & 2.35 & 0.57 \\
\hline $725-B$ & 52.14 & 14.18 & 3.16 & 12.45 & 0.20 & 7.94 & 4.20 & 1.13 & 2.00 & 0.60 \\
\hline $725-C$ & 52.45 & 14.60 & 3.17 & $11 . \pi 7$ & 0.23 & 8.25 & 4.13 & 0.88 & 1.94 & 0.59 \\
\hline $92-B$ & 52.22 & 14.19 & 3.15 & 12.14 & 0.21 & 7.94 & 4.27 & 1.04 & 2.26 & 0.59 \\
\hline $92-F$ & 52.28 & 14.29 & 3.20 & 12.85 & 0.32 & 7.84 & 3.35 & 1.06 & 2.24 & 0.57 \\
\hline $92-\mathrm{H}$ & 52.61 & 14.50 & 3.13 & 11.64 & 0.21 & 8.30 & 4.16 & 0.86 & 1.97 & 0.61 \\
\hline $912-E$ & 52.30 & 14.31 & 3.02 & 12.37 & 0.23 & 8.09 & 4.04 & 0.79 & 2.28 & 0.58 \\
\hline $915-C$ & 53.16 & 14.49 & 3.07 & 11.01 & 0.22 & 8.09 & 4.05 & 1.22 & 2.10 & 0.60 \\
\hline ALCK-2 & 52.21 & 14.36 & 3.13 & 12.07 & 0.22 & 8.14 & 4.24 & 0.84 & 2.16 & 0.62 \\
\hline SRRF-1 & 52.15 & 14.44 & 3.13 & 12.00 & $0 . \overline{22}$ & 8.38 & 4.31 & 0.70 & 2.11 & 0.55 \\
\hline AVERAGE & 52.24 & 14.33 & 3.12 & 12.22 & 0.23 & 8.09 & 4.09 & .95 & 2.14 & 0.59 \\
\hline$*$ * & 0.43 & 0.17 & 0.05 & 0.61 & 0.03 & 0.18 & 0.30 & 0.18 & 0.13 & 0.02 \\
\hline
\end{tabular}

* Fe listed is $\mathrm{FeO}$; $\mathrm{Fe} 203$ assumed to be $2.00 \%$

* Standard deviation for calculated averages \pm 1 signa 


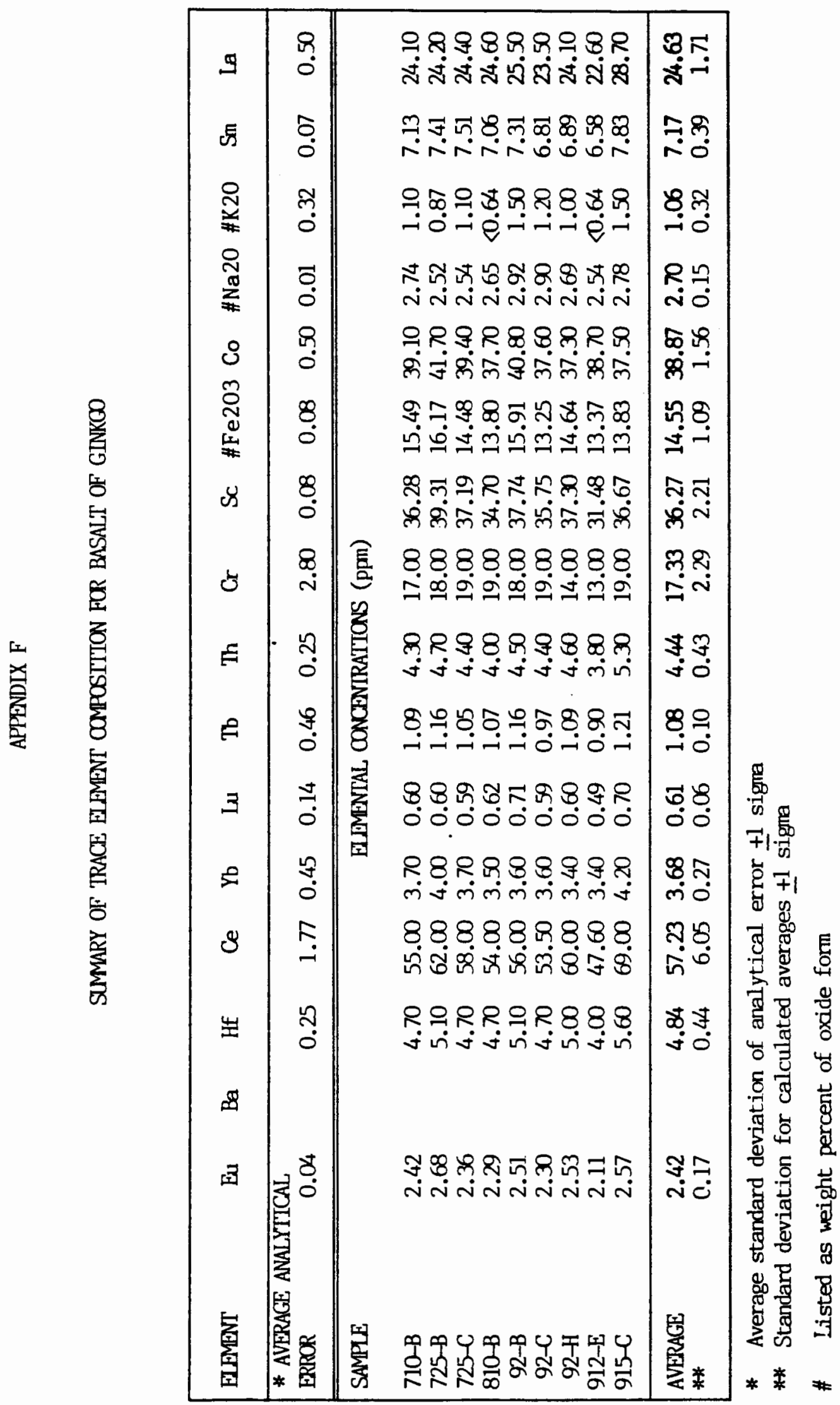


APPENDIX G

SLMMARY OF MAJOR OXIDE COMPOSITION FOR BASALT OF SILVER FALLS

\begin{tabular}{|lcccccccccc|}
\hline ELEMENT & $\mathrm{Si}$ & $\mathrm{AI}$ & $\mathrm{Ti}$ & *Fe & $\mathrm{M}$ & $\mathrm{Ca}$ & $\mathrm{Mg}$ & $\mathrm{K}$ & $\mathrm{Na}$ & $\mathrm{P}$ \\
\hline \hline SAMPLE & \multicolumn{7}{c|}{ WHOLE ROCK WIEGHT PERCENT OF ELAMENT IN OXIDE FORM } \\
710-E & 52.68 & 14.32 & 3.21 & 11.61 & 0.22 & 8.05 & 4.22 & 1.12 & 2.05 & 0.52 \\
711-A & 51.92 & 14.55 & 3.20 & 12.37 & 0.21 & 8.38 & 4.19 & 0.49 & 2.13 & 0.54 \\
711-B1 & 51.77 & 14.26 & 3.25 & 12.64 & 0.22 & 8.30 & 4.33 & 0.81 & 1.90 & 0.53 \\
98-B & 53.11 & 14.53 & 3.19 & 10.99 & 0.20 & 8.28 & 3.96 & 1.06 & 2.16 & 0.53 \\
910-A & 51.98 & 14.14 & 3.15 & 12.56 & 0.22 & 8.08 & 4.41 & 0.85 & 2.08 & 0.53 \\
912-K & 52.70 & 14.14 & 3.07 & 11.96 & 0.22 & 7.89 & 4.05 & 1.27 & 2.19 & 0.52 \\
\hline AVERAGE & 52.20 & 14.28 & 3.14 & 12.30 & 0.22 & 8.12 & 4.22 & 0.87 & 2.13 & 0.53 \\
** & 0.43 & 0.24 & 0.07 & 0.31 & 0.01 & 0.25 & 0.18 & 0.39 & 0.06 & 0.01 \\
\hline
\end{tabular}

* Fe listed is $\mathrm{FeO}$; $\mathrm{Fe} 203$ assumed to be $2.00 \%$

* Standard deviation for calculated averages \pm 1 sigma 


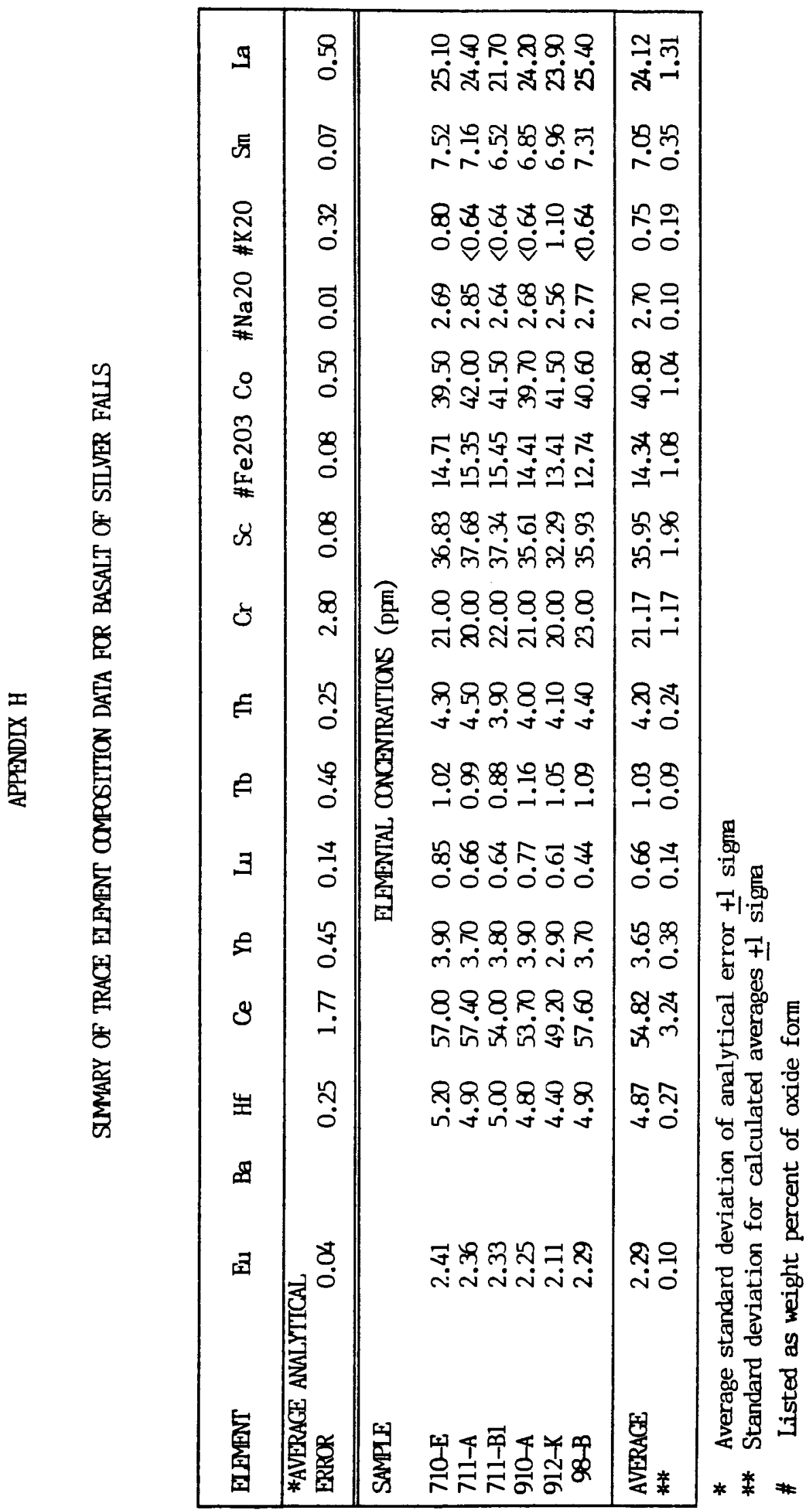


APPENDDX I

SLMMARY OF MAJOR OXIDE COMPOSITION FOR BASALT OF SAND HOLLN

\begin{tabular}{|c|c|c|c|c|c|c|c|c|c|c|}
\hline EIEMENT & Si & Al & $\mathrm{Ti}$ & $* \mathrm{Fe}$ & Mn & $\mathrm{Ca}$ & $\mathrm{Mg}$ & $\mathrm{K}$ & $\mathrm{Na}$ & $\mathrm{P}$ \\
\hline SAMPLE & \multicolumn{10}{|c|}{ WHOLE ROCX WIEGHT PERCENT OF ELAMENT IN OXIDE FORM } \\
\hline 78-D & 52.75 & 14.48 & 3.07 & 11.31 & 0.21 & 7.95 & 4.53 & 1.07 & 2.16 & 0.48 \\
\hline $78-\mathrm{H}$ & 52.38 & 14.26 & 2.99 & 11.97 & 0.21 & 1.87 & 4.68 & 1.06 & 2.07 & 0.49 \\
\hline $79-A$ & 53.53 & 14.88 & 3.06 & 9.64 & 0.21 & 7.73 & 4.27 & 1.90 & 2.29 & 0.50 \\
\hline $79-B$ & 51.85 & 14.63 & 3.01 & 10.87 & 0.27 & 8.86 & 4.01 & 1.83 & 2.16 & 0.51 \\
\hline $79-C$ & 54.76 & 15.12 & 3.16 & 9.26 & 0.20 & 7.28 & 4.04 & 1.43 & 2.23 & 0.52 \\
\hline $79-\mathrm{F}$ & 50.73 & 14.93 & 3.02 & 12.19 & 0.22 & 8.50 & 4.73 & 0.94 & 2.25 & 0.49 \\
\hline $79-6$ & 53.04 & 15.11 & 3.07 & 12.61 & 0.22 & 6.5 & 4.72 & 0.20 & 2.02 & 0.52 \\
\hline $724-B$ & 52.37 & 14.50 & 2.98 & 11.77 & 0.24 & 8.22 & 3.90 & 1.08 & 2.42 & 0.52 \\
\hline D-D25 & 52.25 & 14.38 & 2.99 & 12.39 & 0.22 & 8.04 & 4.22 & 1.05 & 1.96 & 0.51 \\
\hline $725-E$ & 52.04 & 14.91 & 3.13 & 12.72 & 0.18 & 7.82 & 3.63 & 0.97 & 2.07 & 0.53 \\
\hline 731-F & 52.10 & 14.26 & 3.05 & 11.96 & 0.19 & 7.89 & 4.49 & 1.18 & 2.39 & 0.49 \\
\hline $731-G$ & 53.58 & 14.96 & 3.13 & 10.27 & 0.19 & 7.95 & 3.53 & 1.26 & 2.60 & 0.53 \\
\hline $731-\mathrm{H}$ & 52.71 & 14.44 & 2.93 & 11.58 & 0.21 & 8.10 & 3.87 & 1.23 & 2.44 & 0.50 \\
\hline $810-A$ & 52.65 & 14.39 & 3.00 & 12.19 & 0.21 & 8.00 & 4.07 & 1.03 & 1.97 & 0.49 \\
\hline $98-A$ & 52.61 & 14.54 & 3.06 & 11.01 & 0.21 & 8.96 & 4.76 & 0.24 & 2.10 & 0.49 \\
\hline 99-I & 52.12 & 14.31 & 2.95 & 12.28 & 0.21 & 7.80 & 4.73 & 1.09 & 2.02 & 0.49 \\
\hline $911-C$ & 52.63 & 14.37 & 2.98 & 11.75 & 0.20 & 7.90 & 4.01 & 1.24 & 2.41 & 0.51 \\
\hline 911-D & 52.40 & 14.43 & 2.96 & 12.04 & 0.24 & 8.35 & 3.97 & 0.77 & 2.34 & 0.49 \\
\hline 911-E & 52.81 & 14.86 & 2.97 & 10.91 & 0.21 & 8.87 & 4.33 & 0.49 & 2.09 & 0.48 \\
\hline 912-E & 52.62 & 14.47 & 2.99 & 11.36 & 0.21 & 8.07 & 4.22 & 1.22 & 2.34 & 0.49 \\
\hline $912-G$ & 53.00 & 14.63 & 3.02 & 10.89 & 0.21 & 8.86 & 4.20 & 0.62 & 2.08 & 0.49 \\
\hline 912 J & 52.72 & 14.40 & 3.02 & 11.47 & 0.21 & 8.02 & 4.14 & 1.21 & 2.31 & 0.50 \\
\hline 915-E & 52.01 & 14.20 & 2.99 & 12.23 & 0.21 & 8.01 & 4.66 & 1.04 & 2.16 & 0.49 \\
\hline $915-F$ & 52.44 & 14.58 & 3.00 & 11.34 & 0.21 & 8.35 & 4.54 & 0.98 & 2.08 & 0.50 \\
\hline SRRF-2 & 52.20 & 14.50 & 3.02 & 11.89 & 0.20 & 8.57 & 4.71 & 0.43 & 2.01 & 0.48 \\
\hline SRRF-2F & 52.49 & 14.50 & 3.00 & 11.77 & 0.21 & 8.49 & 4.28 & 0.43 & 2.32 & 0.50 \\
\hline AVERAGE & 52.57 & 14.58 & 3.02 & 11.53 & 0.21 & 8.11 & 4.28 & 1.00 & 2.20 & 0.52 \\
\hline & 0.71 & 0.27 & 0.06 & 0.85 & 0.02 & 0.53 & 0.36 & 0.42 & 0.17 & 0.01 \\
\hline
\end{tabular}

* Fe listed is $\mathrm{FeO}$; $\mathrm{Fe} 203$ assumed to be $2.00 \%$

* Standard deviation for calculated averages \pm 1 signa 


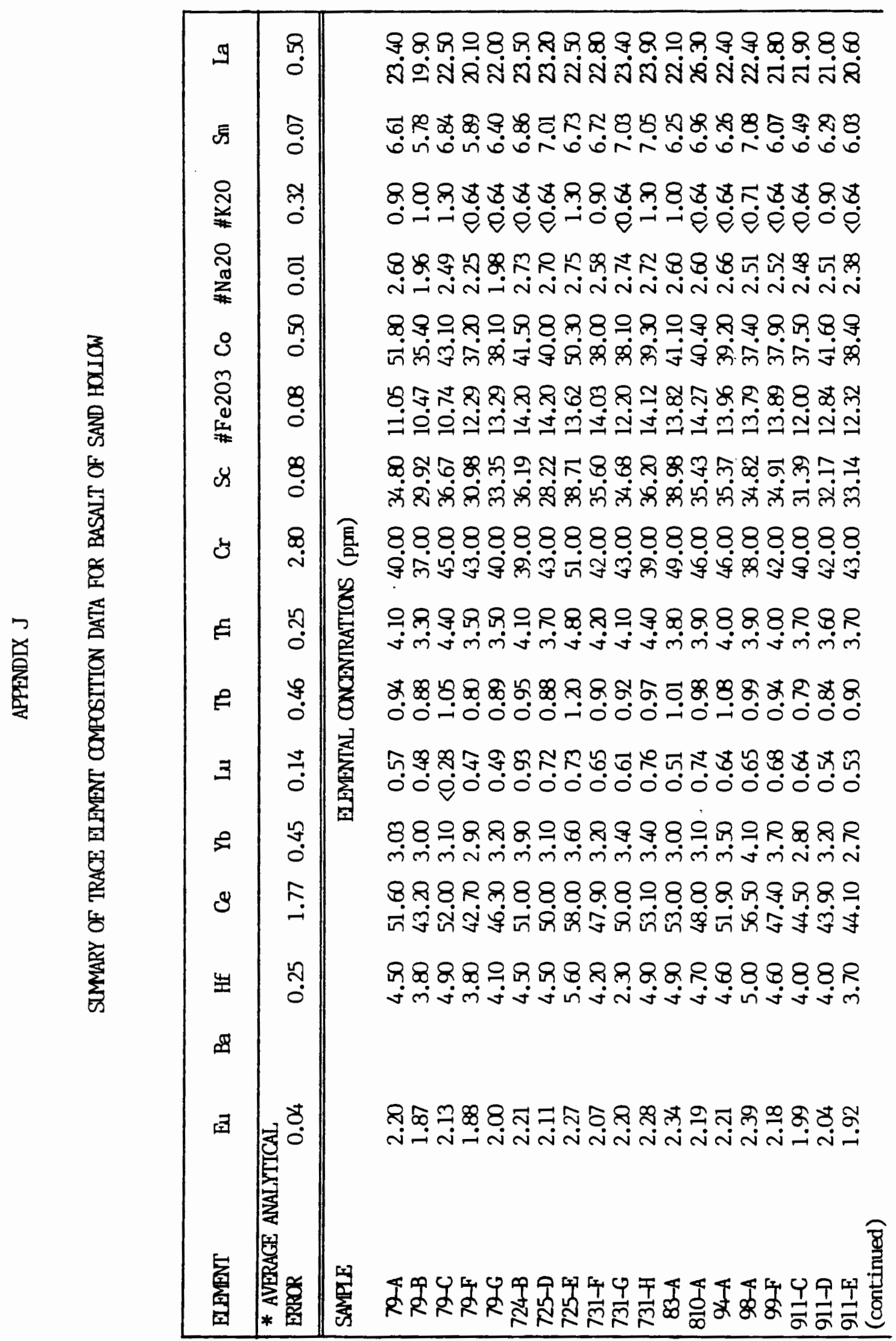




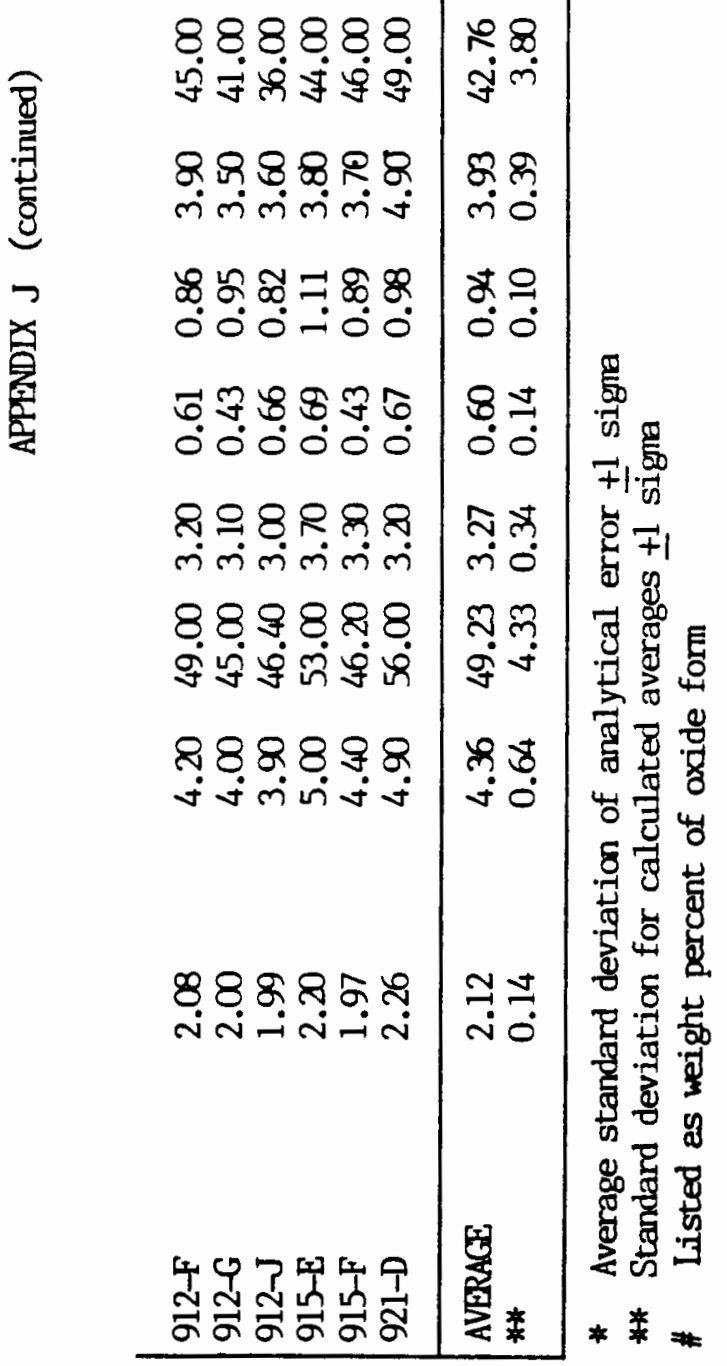


APPENDIX K

SUMMARY OF MAJOR OXIDE OOMPOSTTION FOR BASALT OF SENTINEL GAP

\begin{tabular}{|c|c|c|c|c|c|c|c|c|c|c|}
\hline EIPMENT & $\mathrm{Si}$ & A1 & $\mathrm{Ti}$ & 虾e & $\mathrm{Mn}$ & $\mathrm{Ca}$ & Mg & $\mathrm{K}$ & $\mathrm{Na}$ & $\mathrm{P}$ \\
\hline SAMPLE & \multicolumn{10}{|c|}{ WHOLE ROCK WIEGHT PERCENT OF EJEMENT IN OXIDE FORM } \\
\hline $724-\mathrm{A}$ & 52.45 & 14.22 & 3.14 & 12.04 & 0.19 & 7.74 & 3.91 & 1.25 & 2.52 & 0.52 \\
\hline $724-E$ & 52.35 & 14.30 & 3.13 & 11.73 & 0.22 & 8.13 & 3.94 & 1.12 & 2.55 & 0.52 \\
\hline $726-\mathrm{A}$ & 52.23 & 14.23 & 3.14 & 12.37 & 0.26 & 7.99 & 3.83 & 1.18 & 2.26 & 0.51 \\
\hline $89-B$ & 52.51 & 14.30 & 3.09 & 12.02 & 0.25 & 8.00 & 4.21 & 0.99 & 2.10 & 0.52 \\
\hline $92-E$ & 52.00 & 14.43 & 3.02 & 11.96 & 0.23 & 8.41 & 4.66 & 0.79 & 2.00 & 0.51 \\
\hline $92-K$ & 52.52 & 14.07 & 3.10 & 12.13 & 0.21 & 7.80 & 4.44 & 1.13 & 2.10 & 0.52 \\
\hline $915-B$ & 52.20 & 14.18 & 3.12 & 12.41 & 0.24 & 7.95 & 4.14 & 1.05 & 2.19 & 0.52 \\
\hline$A W C K-1$ & 52.89 & 14.36 & 3.19 & 11.35 & 0.20 & 8.03 & 4.05 & 1.13 & 2.27 & 0.52 \\
\hline AVERAG & 52.39 & 14.26 & 3.12 & 12.00 & 0.23 & 8.01 & 4.15 & 1.08 & 2.25 & 0.52 \\
\hline & 0.27 & 0.11 & 0.05 & 0.34 & 0.02 & 0.21 & 0.28 & 0.14 & 0.20 & 0.00 \\
\hline
\end{tabular}

* Fe listed is $\mathrm{FeO} ; \mathrm{Fe} 203$ assumed to be $2.00 \%$

* Standard deviation for calculated averages \pm 1 sigra 







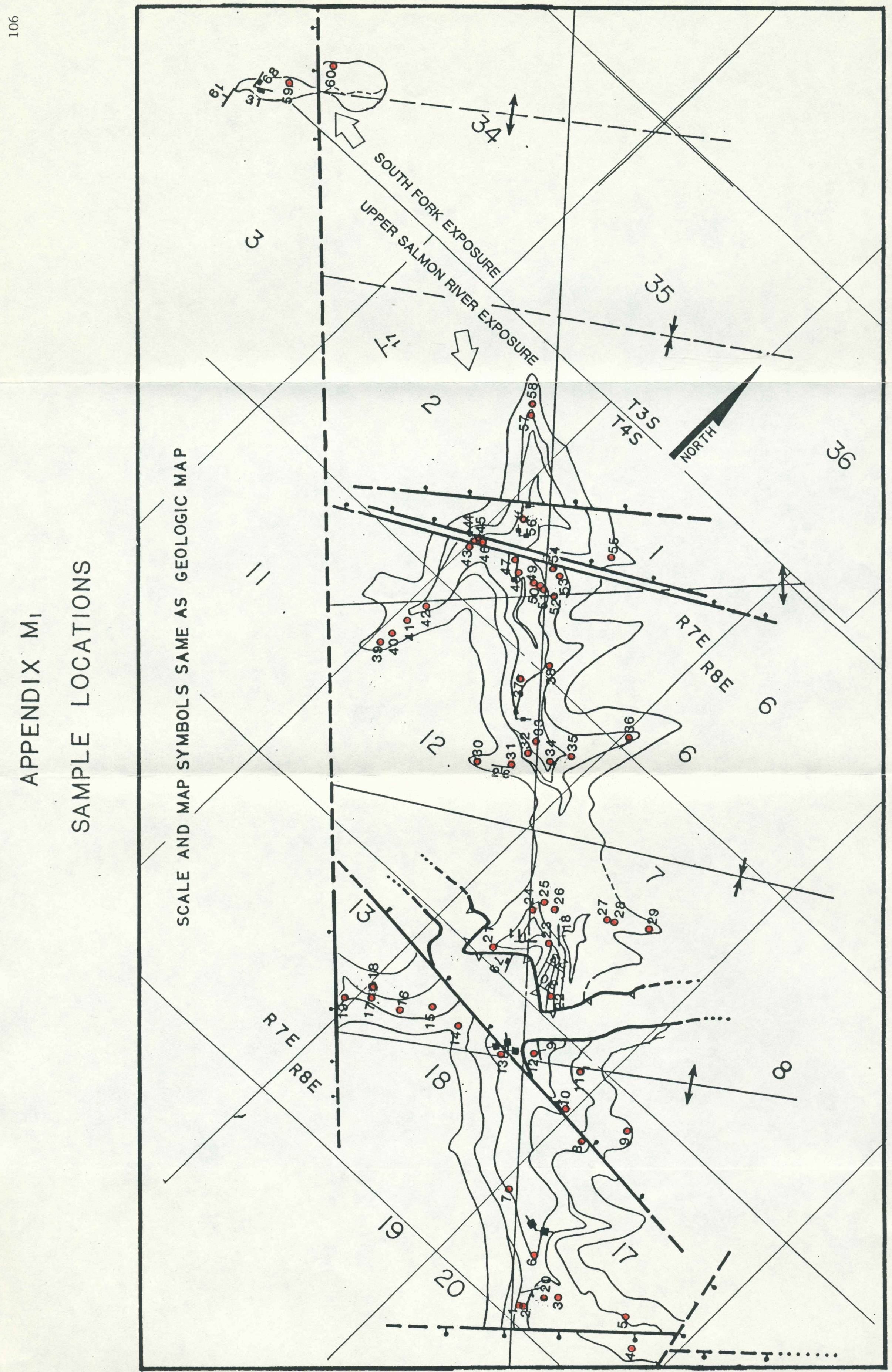









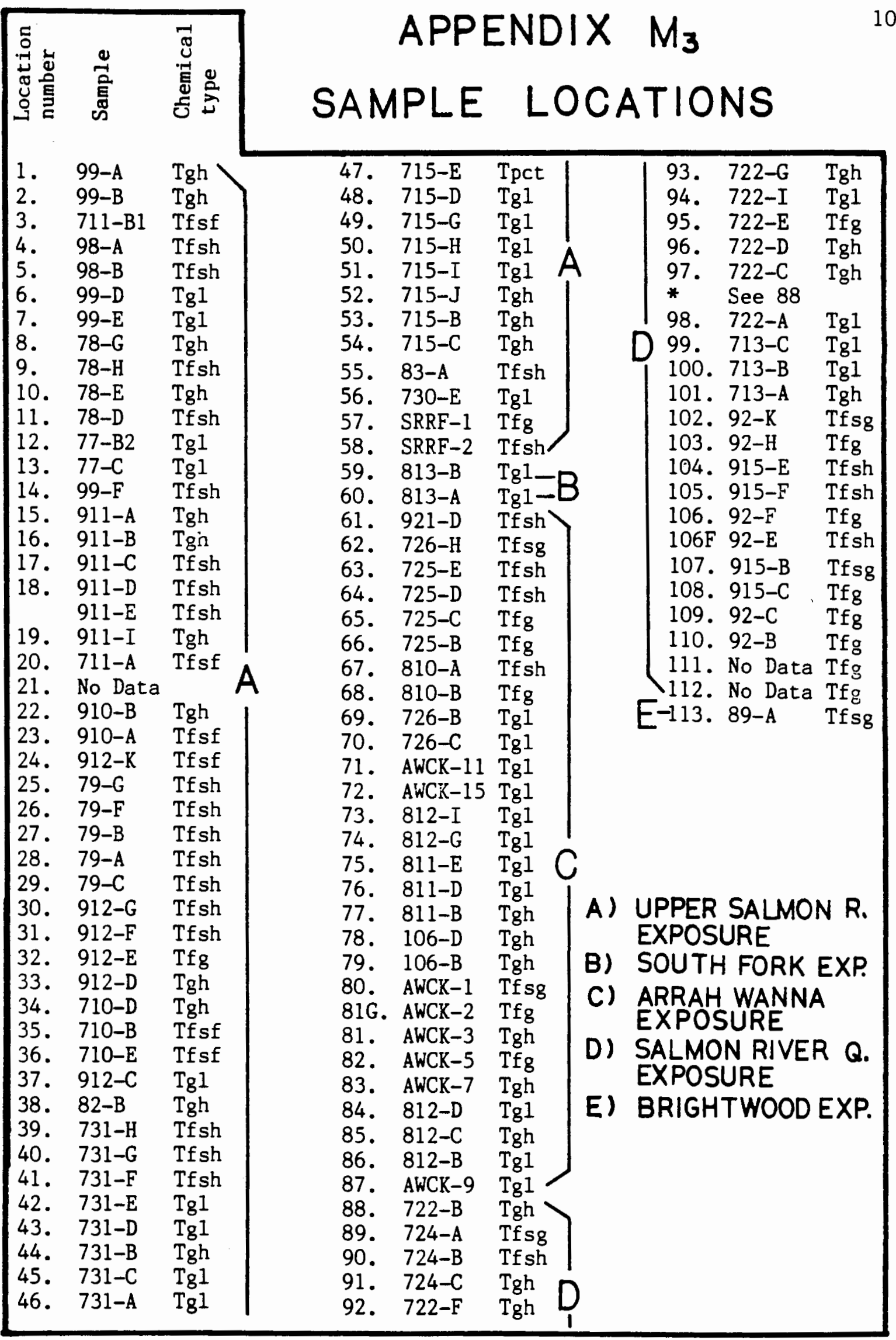

